\title{
Analysis of Residential, Industrial and Commercial Sector Responses to Potential Electricity Supply Constraints in the 1990s.
}
Z. J. Fisher
J. M. Fang
A. J. Lyke
J. R. Krudener
R. M. Scheer, Project Manager

September 1986

Prepared for the U.S. Department of Energy under Contract DE-AC06-76RLO 1830

Pacific Northwest Laboratory Operated for the U.S. Department of Energy by Battelle Memorial Institute 


\title{
DISCLAIMER
}

This report was prepared as an account of work sponsored by an agency of the United States Government. Neither the United States Government nor any agency thereof, nor any of their employees, makes any warranty, express or implied, or assumes any legal liability or responsibility for the accuracy, completeness, or usefulness of any information, apparatus, product, or process disclosed, or represents that its use would not infringe privately owned rights. Reference herein to any specific commercial product, process, or service by trade name, trademark, manufacturer, or otherwise, does not necessarily constitute or imply its endorsement, recommendation, or favoring by the United States Government or any agency thereof. The views and opinions of authors expressed herein do not necessarily state or reflect those of the United States Government or any agency thereof.

\author{
PACIFIC NORTHWEST LABORATORY \\ operated by \\ BATTELLE \\ for the \\ UNITED STATES DEPARTMENT OF ENERGY \\ under Contract DE-AC06-76RLO 1830
}

Printed in the United States of America

Available from

National Technical Information Service United States Department of Commerce

S285 Port Royal Road

Springfield, Virginia 22161

NTIS Price Codes

Microfiche $\mathrm{A} 01$

$\begin{array}{ll} & \text { Printed Copy } \\ \text { Pages } & \text { Price } \\ \text { Codes }\end{array}$

001-025 A02

026-050 A03

051-075 A04

076-100 A05

101-125 A06

126-150 A07

151-175 AOB

176-200 A09

201-225 $\quad 1010$

226-250 A011

251-275 A012

276-300 $\quad A 013$ 


\author{
Z. J. Fisher \\ J. M. Fang \\ A. J. Lyke \\ J. R. Krudener \\ R. M. Scheer, Project Manager
}

September 1986

Prepared for

the U.S. Department of Energy

under Contract DE-ACO6-76RLO 1830

Pacific Northwest Laboratory

Richland, Washington 99352 


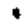


EXECUTIVE SUMMARY

There is considerable debate over the ability of electric generation capacity to meet the growing needs of the U.S. economy in the 1990s. This study provides new perspective on that debate and examines the possibility of power outages resulting from electricity supply constraints. Previous studies have focused on electricity supply growth, demand growth, and on the linkages between electricity and economic growth. This study assumes the occurrence of electricity supply shortfalls in the 1990s and examines the steps that homeowners, businesses, manufacturers, and other electricity users might take in response to electricity outages.

The user perspective is an important but often overlooked ingredient in the analysis of electricity supply adequacy. Ultimately, the main issue is whether or not the electricity needs of users can be satisfied at acceptable costs. It is the premise of this study that users can adopt a number of strategies that have the potential to reduce the economic impacts of electricity outages on their activities. We identified six:

1. self-generate electricity

2. switch from electricity to other energy sources

3. purchase more electricity efficient equipment

4. relocate

5. change the electricity consumption patterns

6. reduce the level of their electricity consuming activities.

We then analyzed data from homeowners, businesses and manufacturers implementing some or all of these actions in order to determine why they were being pursued, what the costs were, and how much electricity was being produced or saved. The data came from utility experience with conservation and load management programs, business experience with energy management technologies, trade journals, and other relevant literature and contacts. Table ES.1 lists the specific actions that were analyzed in this study.

To develop a realistic picture of how users would respond to electricity constraints in the 1990s, we needed to know the frequency, duration and effect of the supply constraints that we assume will occur. We considered several 
TABLE ES.1. Responses to Electricity Supply Constraints by Sector

\begin{tabular}{|c|c|c|c|c|}
\hline & & Industrial & Commercial & Residential \\
\hline 1. & Self-generation & $\begin{array}{l}\text { cogeneration; } \\
\text { emergency } \\
\text { generation }\end{array}$ & cogeneration & low potential \\
\hline 2. & Fuel-switching & $\begin{array}{l}\text { examples not } \\
\text { available }\end{array}$ & $\begin{array}{l}\text { examples not } \\
\text { available }\end{array}$ & $\begin{array}{l}\text { electricity to } \\
\text { gas for space } \\
\text { heat }\end{array}$ \\
\hline 3. & Relocation & $\begin{array}{l}\text { a) uminum indus- } \\
\text { try in Pacific } \\
\text { Northwest }\end{array}$ & $\begin{array}{l}\text { examples not } \\
\text { available }\end{array}$ & $\begin{array}{l}\text { examples not } \\
\text { available }\end{array}$ \\
\hline 1 & $\begin{array}{l}\text { Higher Efficiency } \\
\text { Technologies }\end{array}$ & $\begin{array}{l}\text { high efficiency } \\
\text { motors }\end{array}$ & $\begin{array}{l}\text { thermal-storage; } \\
\text { energy manage- } \\
\text { ment systems }\end{array}$ & $\begin{array}{l}\text { thermal- } \\
\text { storage; more } \\
\text { efficient } \\
\text { appliances }\end{array}$ \\
\hline 5. & $\begin{array}{l}\text { Timing of } \\
\text { Activities }\end{array}$ & $\begin{array}{l}\text { response to } \\
\text { time-of-use } \\
\text { rates }\end{array}$ & $\begin{array}{l}\text { response to } \\
\text { time-of-use } \\
\text { rates }\end{array}$ & $\begin{array}{l}\text { response to } \\
\text { time-of-use } \\
\text { rates }\end{array}$ \\
\hline 6. & $\begin{array}{l}\text { Level of Activi- } \\
\text { Activities }\end{array}$ & $\begin{array}{l}\text { response to } \\
\text { interruptible } \\
\text { rates }\end{array}$ & $\begin{array}{l}\text { response to } \\
\text { interruptible } \\
\text { rates }\end{array}$ & $\begin{array}{l}\text { response to } \\
\text { control of air- } \\
\text { conditioners, } \\
\text { water heaters, } \\
\text { space heaters }\end{array}$ \\
\hline
\end{tabular}

supply availability scenarios. One called for substantial electricity shortfalls to occur based on fuel shortages or insufficient base-load generation capacity; a situation many developing nations face today where prolonged outages can occur frequently. Another scenario that was considered called for no shortfalls in the 1990 s due to slower than expected demand growth due to a sluggish economy and higher electricity prices.

The scenario chose called for supply constraints to occur during peak periods. Users in the 19905 would frequently experience brief electricity outages due to excessive seasonal peak demands on utilities. In order to effectively evaluate the economic feasibility and potential for various user responses, we defined a specific supply constraint scenario that called for outages to occur 10 to 15 times per year lasting 4 to 6 hours. This scenario 
and resulting outage pattern is consistent with Department of Energy projections and with the current experiences of utilities in Caifornia and Texas, where peak constraints have recently arisen.

One factor relevant to evaluating the potential responses of users under peak electricity supply constraints involves the costs that consumers would actually face in outage situations. For users that suffer high costs, such as factories forced to shut down temporarily for the day, expensive alternatives such as self-generation may be economically viable. For users that experience lower costs in outage situations, such as residences, tolerance may be the most economically viable option. Using the peak constraints scenario as a point of departure, we evaluated the potential of each of the six strategies identified earlier. We conclude the following:

- Peak supply constraints in the 1990s do not appear likely to result in severe problems for the U.S. economy. Electricity users with high outage costs le.g., those in the industrial and commercial sectors respectively), have several strategies available to them to reduce, avoid or mitigate the economic costs of electricity supply disruptions. Electricity users with lower outage costs are not likely to suffer substantially under the peak supply constraints scenario.

- Technological advances have and will continue to increase the choices and reduce the costs of power outage avoidance strategies. New combined cycle turbines have increased the efficiency of self-generation units and several firms are actively marketing small generators for industrial and commercial uses. More efficient industrial motors, commercial lighting and home appliances have also been developed and are penetrating the market.

- Electric utility programs to reduce peak demand such as time-of-use rates and interruptible service agreements have been spreading rapidly across the U.S. These programs provide financial incentives to electricity users that increase the cost-effectiveness of load 
shaping technologies such as thermal storage, energy management systems and direct load control. Furthermore, these programs can reduce peak electricity demands as consumers change their consumption habits to save money on their electric bill.

- For the industrial sector, self-generation (including cogeneration) appears to have the greatest potential. In addition to the technology advances referred to above, financial incentives from the Public Utilities Regulatory Policy Act (PURPA) and falling oil and gas prices make this strategy increasingly attractive.

- For the commercial sector, cool storage in office bujldings with large cooling loads appears to be the response with the greatest potential. Realizing this potential requires utility incentive programs to compensate purchasers of this equipment for the higher initial cost compared to conventional cooling equipment. Commercial cogeneration is another response with high potential. This option appears suitable for new applications such as restaurants, laundries, hospitals and other businesses that have significant requirements for steain.

- For the residential sector, peak outage costs appear to be low compared to other sectors. Subsequently, few of the options examined appear economically justifiable without subsidies from utilities or others. Significant reductions in peak demand appear possible under utility direct control of end-use loads such as space heating, water heating and air conditioning.

- Additional research in several areas may be useful. Because supply constraints are most likely to occur on a regional basis, analys is of user response on a regional basis may provide more accurate estimates of potential. Availability of options doesn't guarantee their adoption. Further study might focus on consumer motivation and investment decision-making criteria. Finally, further analys is of the market potential of industrial self-generation is warranted to account for the effects of rapidly changing market conditions due to 
falling oil prices, and an uncertain regulatory environment steming from recent steps to deregulate portions of the electric utility industry. 
CONTENTS

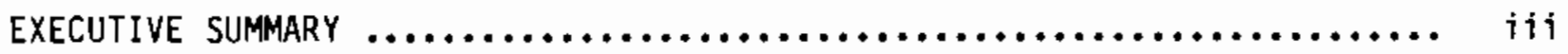

1.0 INTRODUCTION............................................. 1

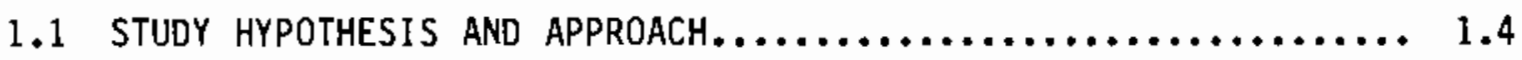

1.2 THE ELECTRICITY SUPPLY CONSTRAINT DEFINITION............. 1.5

1.2.1 Type of Electricity Supply Constraint Selected

for This Study ................................. 1.7

1.3 SCOPE AND LIMITATIONS $\ldots \ldots \ldots \ldots \ldots \ldots \ldots \ldots \ldots \ldots \ldots \ldots \ldots, 1.9$

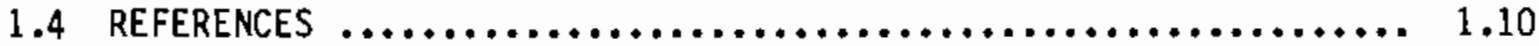

2.0 COSTS OF POWER OUTAGES TO ELECTRICITY USERS $\ldots \ldots \ldots \ldots \ldots \ldots \ldots \ldots . .1$

2.1 OUTAGE COSTS $\ldots \ldots \ldots \ldots \ldots \ldots \ldots \ldots \ldots \ldots \ldots \ldots \ldots \ldots \ldots \ldots, 2.1$

2.1.1 Determinants of Outage Costs $\ldots \ldots \ldots \ldots \ldots \ldots \ldots \ldots \ldots, 2.1$

2.2 RESIDENTIAL SECTOR OUTAGE COSTS $\ldots \ldots \ldots \ldots \ldots \ldots \ldots \ldots \ldots \ldots, 2.3$

2.2.1 Methods for Measuring Residential Outage Costs ........ 2.3

2.2.2 Estimates of Residential Costs .................. 2.5

2.3 COMMERCIAL SECTOR OUTAGE COSTS $\ldots \ldots \ldots \ldots \ldots \ldots \ldots \ldots \ldots \ldots \ldots . .7$

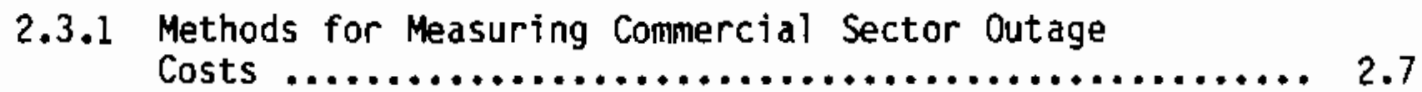

2.3.2 Estimates of Costs of Outage to Commercial Users ...... 2.8

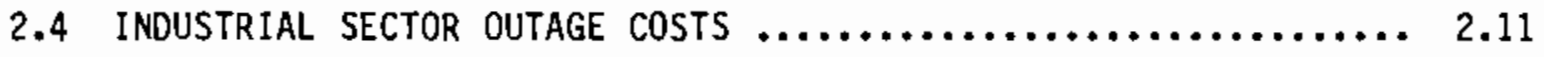

2.4.1 Methods for Estimating Industrial Sector Outage Costs ....................................... 2.11

2.4.2 Estimates of Industrial Sector Outage Costs $\ldots \ldots \ldots \ldots .2 .12$

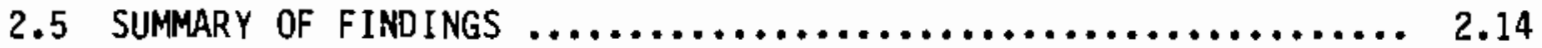

2.6 REFERENCES $\ldots \ldots \ldots \ldots \ldots \ldots \ldots \ldots \ldots \ldots \ldots \ldots \ldots \ldots \ldots \ldots \ldots \ldots, 2.16$

3.0 RESIOENTIAL SECTOR RESPONSE TO ELECTRICITY SUPPLY CONSTRAINTS...... 3.1

3.1 RESIDENTIAL ELECTRICITY CONSUMPTION $1985-1995 \ldots \ldots \ldots \ldots \ldots \ldots .2$ 
3.1.1 Residential Sector Peak Demand $\ldots \ldots \ldots \ldots \ldots \ldots \ldots \ldots, 3.2$

3.2 SHIFTING THE TIMING OF ELECTRICITY USE IN RESPONSE TO

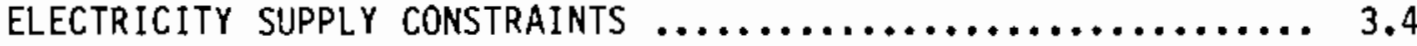

3.2.1 Background $\ldots \ldots \ldots \ldots \ldots \ldots \ldots \ldots \ldots \ldots \ldots \ldots \ldots \ldots, 3.4$

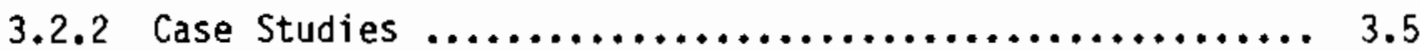

3.2.3 Potential for Peak Demand Reduction ................ 3.13

3.3 ADOPTION OF THERMAL ENERGY STORAGE AS A RESPONSE BY RESIDENTIAL USERS TO ELECTRICITY SUPPLY CONSTRAINTS $\ldots \ldots \ldots \ldots .3 .14$

3.3.1 Available TES Technologies $\ldots \ldots \ldots \ldots \ldots \ldots \ldots \ldots \ldots \ldots . . . \ldots \ldots$

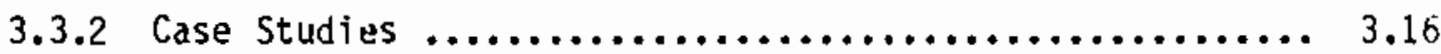

3.3.3 Potential Peak Demand Reduction $\ldots \ldots \ldots \ldots \ldots \ldots \ldots \ldots . \ldots . . .23$

3.4 PURCHASE OF ENERGY EFFICIENT APPLIANCES AS A RESPONSE BY RESIDENTIAL USERS TO ELECTRICITY SUPPLY CONSTRAINTS $\ldots \ldots \ldots \ldots \ldots . .3 .24$

3.4 .1 Uti]ity Experience $\ldots \ldots \ldots \ldots \ldots \ldots \ldots \ldots \ldots \ldots \ldots \ldots, 3.25$

3.4.2 Consumer Acceptance $\ldots \ldots \ldots \ldots \ldots \ldots \ldots \ldots \ldots \ldots \ldots \ldots . . .6 .27$

3.4.3 Potential for Peak Demand Reduction................. 3.28

3.5 REDUCING THE LEVEL OF ELECTRICITY CONSUMPIION BY

RESIDENTIAL USERS IN RESPONSE TO ELECTRICITY

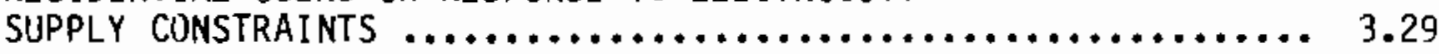

3.5.1 Appliances Controlled by DLC ..................... 3.30

3.5 .2 Case Studies $\ldots \ldots \ldots \ldots \ldots \ldots \ldots \ldots \ldots \ldots \ldots \ldots \ldots \ldots, 3.32$

3.5 .3 Conclusions $\ldots \ldots \ldots \ldots \ldots \ldots \ldots \ldots \ldots \ldots \ldots \ldots \ldots \ldots, 3.44$

3.5.4 Potential Peak Demand Reduction ................... 3.45

3.6 FUEL SHITCHING AS A RESPONSE TO ELECTRICITY SUPPLY

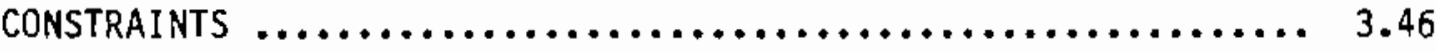

3.6.1 Discussion of Fuel Switching Options $\ldots \ldots \ldots \ldots \ldots \ldots \ldots .3 .48$

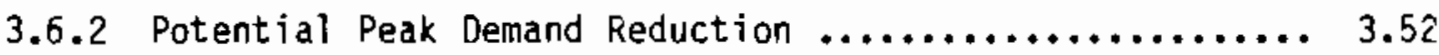

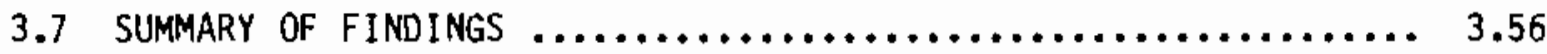

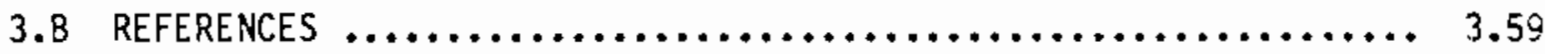


4.0 INDUSTRIAL SECTOR RESPONSE TO ELECTRICITY SUPPLY CONSTRAINTS $\ldots \ldots \ldots 4.1$

4.1 INDUSTRIAL ELECTRICITY CONSUMPTION $1985-1995 \ldots \ldots \ldots \ldots \ldots \ldots . .2$

4.1.1 Industrial Sector Peak Demand $\ldots \ldots \ldots \ldots \ldots \ldots \ldots \ldots \ldots \ldots \ldots \ldots \ldots, 4.4$

4.2 REDUCING THE LEVEL OF ELECTRICITY USE IN RESPONSE TO

SUPPLY CONSTRAINTS $\ldots \ldots \ldots \ldots \ldots \ldots \ldots \ldots \ldots \ldots \ldots \ldots \ldots \ldots \ldots \ldots, 4.7$

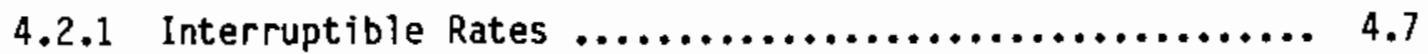

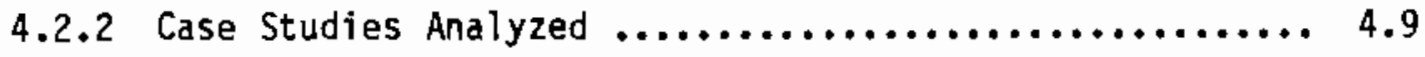

4.2 .3 Incentives $\ldots \ldots \ldots \ldots \ldots \ldots \ldots \ldots \ldots \ldots \ldots \ldots \ldots \ldots \ldots, 4.10$

4.2.4 Reductions in Demand $\ldots \ldots \ldots \ldots \ldots \ldots \ldots \ldots \ldots \ldots \ldots, 4.11$

4.2.5 Potential for Demand Reduction ................... 4.12

4.3 SHIFTING THE TIMING OF ELECTRICITY USE IN RESPONSE TO ELECTRICITY SUPPLY CONSTRAINTS $\ldots \ldots \ldots \ldots \ldots \ldots \ldots \ldots \ldots \ldots, 4.13$

4.3.1 Case Studies Analyzed $\ldots \ldots \ldots \ldots \ldots \ldots \ldots \ldots \ldots \ldots \ldots \ldots, 4.15$

4.3.2 Incentives for Shifting the Timing of Electrical Use ... 4.16

4.3.3 Technical Feasibility of Shifting the Timing of Industrial Activity $\ldots \ldots \ldots \ldots \ldots \ldots \ldots \ldots \ldots \ldots \ldots \ldots, 4.16$

4.3.4 Demonstrated Peak Demand Reductions Under TOU Rates .... 4.18

4.3.5 Potential Peak Demand Reduction ................... 4.19

4.3 .6 Conclusion $\ldots \ldots \ldots \ldots \ldots \ldots \ldots \ldots \ldots \ldots \ldots \ldots \ldots \ldots \ldots \ldots \ldots \ldots \ldots, 4.20$

4.4 ADOPTION OF SELF GENERATION IN RESPONSE TO ELECTRICITY

SUPPLY CONSTRAINTS $\ldots \ldots \ldots \ldots \ldots \ldots \ldots \ldots \ldots \ldots \ldots \ldots \ldots \ldots \ldots, 4.21$

4.4 .1 Cases Analyzed $. \ldots \ldots \ldots \ldots \ldots \ldots \ldots \ldots \ldots \ldots \ldots \ldots \ldots, 4.21$

4.4 .2 Cogeneration $. . \ldots \ldots \ldots \ldots \ldots \ldots \ldots \ldots \ldots \ldots \ldots \ldots \ldots, 4.24$

4.4.3 Potential for Peak Demand Reduction ................ 4.26

4.5 PURCHASE DF ENERGY EFFICIENT TECHNOLOGIES AS A RESPONSE TO

ELECTRICITY SUPPLY CONSTRAINTS $\ldots \ldots \ldots \ldots \ldots \ldots \ldots \ldots \ldots \ldots \ldots, 4.29$

4.5.1 Technologies Examined $\ldots \ldots \ldots \ldots \ldots \ldots \ldots \ldots \ldots \ldots \ldots \ldots \ldots . \ldots \ldots, 4.29$

4.5.2 High Efficiency Electric Motors $. \ldots \ldots \ldots \ldots \ldots \ldots \ldots .4 . \ldots .29$ 
4.5.3 Adjustable Speed Motor Drives .................. 4.31

4.6 RELOCATION IN RESPONSE TO ELECTRICITY SUPPLY CONSTRAINTS $\ldots \ldots \ldots$

4.6 .1 Literature Review ......................... 4.33

4.6 .2 Interview with Industry officials $\ldots \ldots \ldots \ldots \ldots \ldots \ldots . . . . . . . .44$

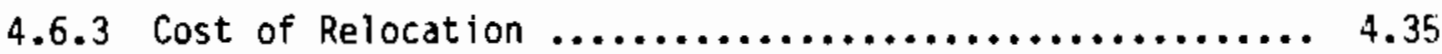

4.6.4 Potential for Peak Demand Reduction ................ 4.36

4.7 SUMMARY OF FINDINGS $\ldots \ldots \ldots \ldots \ldots \ldots \ldots \ldots \ldots \ldots \ldots \ldots \ldots \ldots \ldots \ldots \ldots \ldots$

4.8 REFERENCES $\ldots \ldots \ldots \ldots \ldots \ldots \ldots \ldots \ldots \ldots \ldots \ldots \ldots \ldots \ldots \ldots \ldots \ldots \ldots \ldots \ldots \ldots$

5.0 COMMERCIAL SECTOR RESPONSE TO ELECTRICITY SUPPLY CONSTRAINTS $\ldots \ldots \ldots . .1$

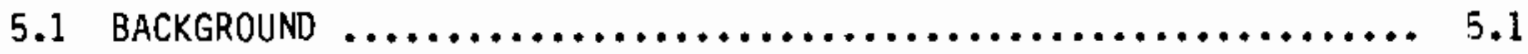

5.2 OVERVIEW OF COMMERCIAL SECTOR RESPONSES TO
ELECTRICITY SUPPLY CONSTRAINTS $\ldots \ldots \ldots \ldots \ldots \ldots \ldots \ldots \ldots \ldots \ldots \ldots \ldots \ldots$

5.3 SHIFTING THE TIMING OF ELECTRICITY USE $\ldots \ldots \ldots \ldots \ldots \ldots \ldots \ldots \ldots \ldots . \ldots$

5.3.1 The Concept of Time-of-Use Rates ................. 5.10

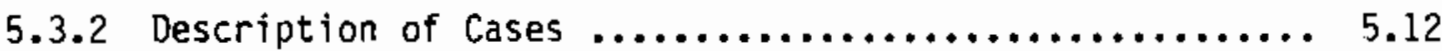

5.3 .3 Customer Participation ....................... 5.14

5.3.4 Potential for Peak Demand Reduction ............... 5.15

5.4 REDUCING THE LEVEL OF ELECTRICITY USE $\ldots \ldots \ldots \ldots \ldots \ldots \ldots \ldots \ldots \ldots . . \ldots$

5.4.1 Description of the Cases $\ldots \ldots \ldots \ldots \ldots \ldots \ldots \ldots \ldots \ldots . \ldots \ldots \ldots$

5.4.2 Customer Acceptance and Participation ............ 5.22

5.4.3 Barriers to Program Participation ................. 5.24

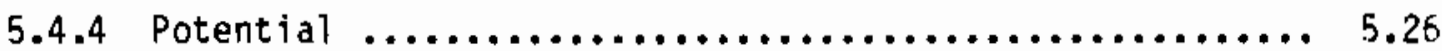

5.5 ADOPTION OF SELF-GENERATION $\ldots \ldots \ldots \ldots \ldots \ldots \ldots \ldots \ldots \ldots \ldots \ldots \ldots . \ldots \ldots$

5.5.1 Cogeneration Opportunities Within Scope of Study ...... 5.27

5.5 .2 Description of the Cases $\ldots \ldots \ldots \ldots \ldots \ldots \ldots \ldots \ldots \ldots \ldots . . \ldots .28$

5.5 .3 Range of Costs and Benefits .................. 5.32 
5.5 .4 Potential $\ldots \ldots \ldots \ldots \ldots \ldots \ldots \ldots \ldots \ldots \ldots \ldots \ldots \ldots \ldots \ldots \ldots . \ldots . \ldots . \ldots \ldots$

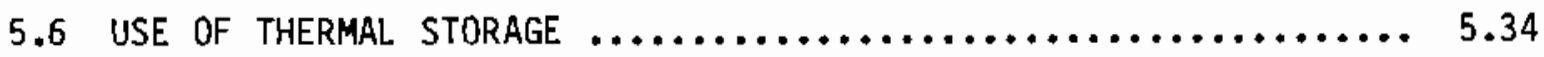

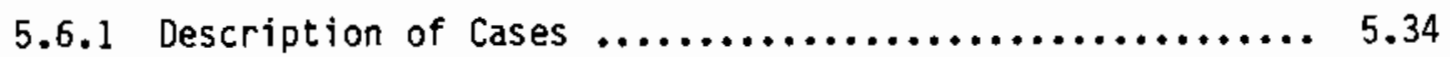

5.6 .2 Range of Costs and Benefits ................... 5.37

5.6 .3 Potential ................................ 5.39

5.7 USE OF ENERgY Management SYSTEMS $\ldots \ldots \ldots \ldots \ldots \ldots \ldots \ldots \ldots \ldots \ldots \ldots \ldots$

5.7.1 General Features of EMS Technologies .............. 5.41

5.7 .2 Description of Cases $\ldots \ldots \ldots \ldots \ldots \ldots \ldots \ldots \ldots \ldots \ldots \ldots \ldots . \ldots \ldots$

5.7 .3 Range of Costs and Benefits $\ldots \ldots \ldots \ldots \ldots \ldots \ldots \ldots \ldots . \ldots .46$

5.7 .4 Potential $\ldots \ldots \ldots \ldots \ldots \ldots \ldots \ldots \ldots \ldots \ldots \ldots \ldots \ldots \ldots \ldots . \ldots . \ldots \ldots$

5.8 SUMMARY OF FINDINGS $\ldots \ldots \ldots \ldots \ldots \ldots \ldots \ldots \ldots \ldots \ldots \ldots \ldots \ldots \ldots \ldots \ldots \ldots \ldots \ldots$

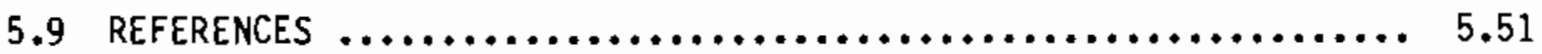




\section{FIGURES}

3.1 Effect of 50,000 ETS Conversions on the AEP System Load Shape Ouring January $17-18,1977 \ldots \ldots \ldots \ldots \ldots \ldots \ldots \ldots \ldots \ldots \ldots \ldots \ldots \ldots \ldots \ldots .18$

3.2 Comparison System Load Curve to the Load Created by a

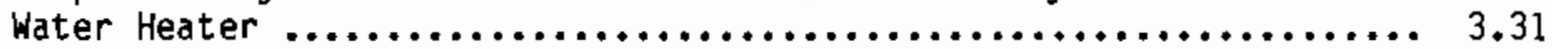

3.3 Standard Water Heaters Valley-Wide Average, February $1981 \ldots \ldots \ldots .3 .35$

3.4 Standard Water Heaters Valley-Wide Average, July $1980 \ldots \ldots \ldots \ldots . .3 .36$

4.1 Dollar Cost as a Function of Percentage of a Firms Load Curtailed..................................................... 4.8

4.2 General Effect of Adopting High Efficiency Technologies .......... 4.30 


\section{TABLES}

ES.1 Responses to Electricity Supply Constraints by Sector $\ldots \ldots \ldots \ldots \ldots$ iv

1.1 Range of Four Types of Electricity Availability/Constraints ....... 1.6

1.2 Scope of Work for This Project $\ldots \ldots \ldots \ldots \ldots \ldots \ldots \ldots \ldots \ldots \ldots \ldots, 1.8$

2.1 Costs of Outages to Residential Sector Uses $\ldots \ldots \ldots \ldots \ldots \ldots \ldots \ldots, 2.6$

2.2 Cost of Outages of 1 and 3 Hours Duration for Residential Electricity Users Estimated by Gilmer and Mack $\ldots \ldots \ldots \ldots \ldots \ldots \ldots, 2.7$

2.3 Survey of Costs of Outages to Commercial Sector Users $\ldots \ldots \ldots \ldots \ldots .2 .10$

2.4 Summary of Outage Costs to Industrial Sector Firms $\ldots \ldots \ldots \ldots \ldots \ldots .2 .13$

3.1 Residential Fuel Consumption by End-Use in $1980 \ldots \ldots \ldots \ldots \ldots \ldots \ldots . .1$

3.2 Peak Demand of Typical 1980 Electrical Appliances During

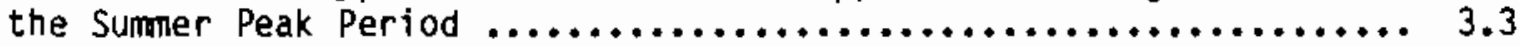

3.3 Estimated Residential Average and Peak Electric Demand, GW ........ 3.3

3.4 Potential Peak Demand Reductions in Response to Time-of-Use

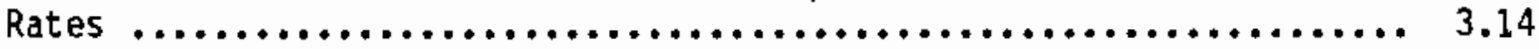

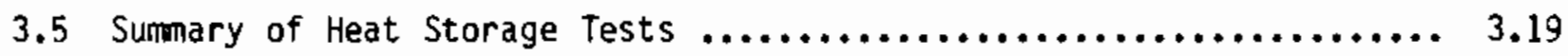

3.6 Summary of Cool Storage Tests $\ldots \ldots \ldots \ldots \ldots \ldots \ldots \ldots \ldots \ldots \ldots \ldots \ldots, 3.20$

3.7 Initial Customer Incentives $\ldots \ldots \ldots \ldots \ldots \ldots \ldots \ldots \ldots \ldots \ldots \ldots \ldots \ldots \ldots \ldots, 3.21$

3.8 Potential Peak Demand Reduction for Thermal Energy Storage Equipment $\ldots \ldots \ldots \ldots \ldots \ldots \ldots \ldots \ldots \ldots \ldots \ldots \ldots \ldots \ldots \ldots \ldots \ldots \ldots, 3.23$

3.9 Comparison of Historic Trends and Best Technology Scenarios for Projecting Residential Electric Energy Consumption in 2005 Energy Consumption in Performance 2005 ..................... 3.25

3.10 Utility Sponsored Efficient Appliance Programs $\ldots \ldots \ldots \ldots \ldots \ldots \ldots .3 .26$

3.11 Peak Load Reductions from Energy Efficient Appliances ............ 3.29

3.12 Direct Load Control Technologies and Characteristics ............ 3.33

3.13 Peak Savings from Direct Load Control Programs for Surveyed Utilities 
3.14 Peak Savings from DLC Programs Selected from the 1981

EPRI Survey

3.15 Potential Peak Demand Reduction from Direct Load Control ......... 3.45

3.16 Potential Methods of Fuel Switching..................... 3.47

3.17 Potential Peak Reductions from Adoption of Gas Heatpumps as a Method of Fuel Switching

3.18 Potential Peak Reductions from Adoption of Gas Appliances

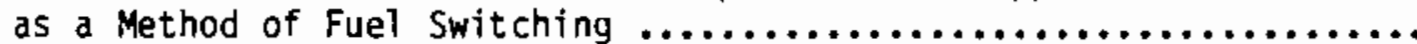

3.19 Potential Peak Reductions from Adoption of Woodstoves as

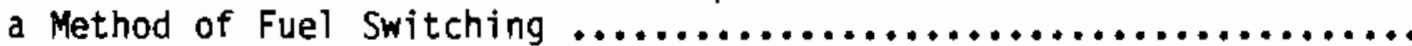

3.20 Potential Peak Reductions from Adoption of Kerosene Heaters

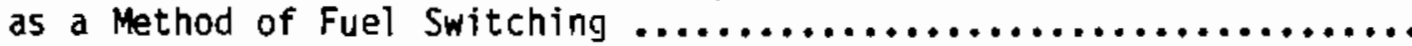

3.21 Total Potential Peak Reductions from Adoption of Various Methods of Fuel Switching

3.22 Review of Primary Response Areas for the Residential Sector ....... 3.57

3.23 Summary of Potential National Peak Demand Reduction by Response Area

4.1 Estimated Purchased and Self-Generated Electricity for 1981........ 4.1

4.2 Historical and Projected Relationship Between GNP Growth and Industrial Electric Demand Growth, 1951-2000

4.3 Expected Electricity Demand for the Industrial Sector, 1980, 1990, $1995 \ldots \ldots \ldots \ldots \ldots \ldots \ldots \ldots \ldots \ldots \ldots \ldots \ldots \ldots \ldots . \ldots \ldots$

4.4 Expected Electrical Demand for the Industrial Sector in $1990 \ldots \ldots . .4 .5$

4.5 Estimated Industrial Peak Electric Demand.................... 4.7

4.6 Customer End Use and Load Summary....................... 4.....

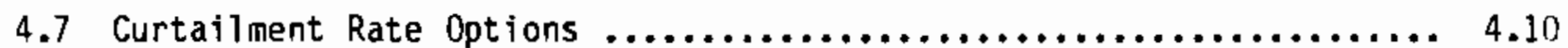

4.8 Customer Demand Impacts............................. 4.11

4.9 Potential Demand Reductions Among SIC's Represented in PG\&E Study............................................. 4.13

4.10 Capital and Operating Costs of Standby Electricity Generating Systems, mid-1980 
4.11 Operating Expenses of Sample Cogeneration System ............. 4.26

4.12 Potential Peak Load Reduction of Responses Evaluated ............4.38

5.1 Commercial Sector Sumner Peak Load Projections ............... 5.3

5.2 Commercial Sector Electricity Use by Building Type, $1984 \ldots \ldots \ldots . . .45$

5.3 Average Electricity Use Intensity for Comercial Buildings in the U.S. by 8uilding Type and by Use of Electricity, 1979 ........ 5.5

5.4 PEPCo's Schedule DC - GT .............................. 5.12

. 


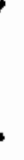




\subsection{INTRODUCTION}

According to Power Engineering's April 1983 survey of electric utility expansion plans, approximately $150 \mathrm{GW}$ of additional electric capacity are planned to be in place by 1991. Yet, Power Engineering also quotes the Electric Power Research Institute (EPRI) as saying that 201 GW of new capacity will be needed by 1991; 112 GW to meet demand growth (assuming a 2.9\% annual growth rate) and 89 GW to replace retiring facilities. Assuming that their projections are correct, that leaves $51 \mathrm{GW}$ in excess demand (equivalent to approximately fifty 1000 M nuclear or coal plants) in 1991. Even if demand growth is lower than expected, the current trend in power plant cancellations has caused the president of Virginia Electric Power Company to remark "the question is not whether there will be electricity supply problems, but how soon."

This outlook for possible future supply constraints is consistent with projections reported by the U.S. DOE's Office of Policy, Planning and Analysis (PPA) which identifies the early to mid-1990s as a period for possible electricity supply constraints (DOE 1983). These projections are based North American Electric Reliability Council (NERC) supply plans and employed three different demand jrowth rates. High demand $(4 \% / y r)$ led to constraints in the late 1980s. Medium demand $(3 \% / y r)$ led to constraints in the early 1990s. Low demand $(2 \% / y r)$ led to constraints in the late 1990s (NERC 1981). Making use of the above DOE projections along with those made by EPRI and Data Resources Incorporated (DRI), Harvard University's Peter Navarro estimates that a 3\% annual growth rate in peak electricity demand will predicate requirements for $400 \mathrm{GW}$ of new generating capacity between now and the year 2000 . This estimate is higher but in line with the above estimates given the longer time frame and the slightly higher assumed rate of demand growth. Navarro postulates that building this additional capacity would require the investment of over $\$ 700$ billion due to the high cost of bringing new generating capacity on-line.

A more recent study using NERC data reports "a capacity shortfall on a nationwide basis by 1996." This study assumed peak demand growth of 
2.5\% annually. On a regional basis, the study reports capacity shortfalls in Texas as early as 1990 and in the northern plains states by 1991.

Using a methodology that incorporates the inherent uncertainties concerning future customer needs, generation retirements and deratings, levels of demand side management, and nonutility generation, EPRI recently estimated a range of values for the amount of additional capacity needed to meet electricity demand in the year 2010. Centering their estimate at $550 \mathrm{GW}$, they have assigned an $80 \%$ probability that between 250 and 850 GW of additional peak generating capacity will be needed between now and the year 2010. They further assign 10\% probabilities that the amount needed will be greater than 850 GN or less than $250 \mathrm{GW}$. This range of estimates appears to be in line with others that have been presented above (EPR! 1985).

Supply constraints can be either capacity constraints or energy constraints. Capacity constraints refer to situations where electric generation capacity (in $\mathrm{kW}$ ) is insufficient relative to peak-demand. Energy constraints refer to situations where the amount of electricity (in $k$ wh) that would be purchased over a specified time period, exceeds electricity supply over the same time period.

Consistent with the PPA projections, capacity constraints rather than energy constraints will be assumed for this study. Section 1.3 provides some details on our assumptions about what is meant by capacity constraints in terms of frequency, duration, warning and price response.

It is not within the scope of this study to forecast electricity demand, resources, or supply constraints. We propose to make use of existing projections, and where these projections lack sufficient detail for our purposes, such as specifying the frequency of electricity outages in 1995, we will make simplifying assumptions based on expert judgment and our review of the literature.

It is also not within the scope of this study to provide detailed anaiysis of how the utility industry would function given hypothetical capacity constraints in the U.S. in the 19g0s. This subject has been addressed in studies sponsored by the Electric Power Research Institute (1978) and others that have 
examined the relative costs of excess capacity versus capacity constraints. Rather, the purpose of this study is to analyze the potential for residential, commercial, and industrial electricity users to respond to electricity supply constraints if and when they occur. The focus of this study is on user responses and not utility responses.

Throughout this study, we purposely avoid undertaking any form of speculation concerning probable changes in the structure of the electricity generation industry as well as changes in the generation technologies that are available to utilities. The widespread adoption of any of a number of new technologies currently being developed could have significant impact on the availability of generating capacity over the next fifteen years and thus would impact upon the existence of supply constraints.(a)

Through this analysis we hope to broaden the discussion over future electricity supply constraints to include user responses in addition to the usual call for new power plants. At the outset of this study several possible userinitiated responses have been identified:

- Users can generate their own electricity as sometimes occurs in hospitals, and telephone companies.

- Users can switch from electric to nonelectric fuels as occurs when homeowners switch from electric to gas or oil heat.

- Users can purchase more energy efficient equipment such as insulation, heat pumps, energy management systems, or cogeneration equipment.

- Users can relocate to within the U.S. or outside the U.S. to avoid the costs or disruptions associated with constraints in electricity supply.

- Users can change the timing of their electricity consuming activities to times of the day when electricity is available.

- Users can reduce the level of their electricity consuming activities.

(a) For a comprehensive discussion of new technologies that may become available to utilities over the next few decades see OTA (1986). 
The extent to which any of these responses are adopted by electricity users (if at all) depends on many factors. A list of the chief factors would include:

- the frequency of the supply constraints

- the duration of the supply constraints

- the amount of the electricity price increase due to the supply constraints

- the amount of leadtime (warning) that users have before supply constraints occur

- the regulatory, administrative, and financial costs of adopting particutar responses.

\subsection{STUDY HYPOTHESIS AND APPROACH}

The research hypothesis that underlies this analysis is as follows:

Users of electricity will not suffer economic catastrophe if confronted with electricity capacity constraints in the 1990 s because techniques such as self-generation and load-management offer electricity users cost-effective alternatives (given proper incentives) to going without electricity.

The approach for addressing this hypothesis involves reviewing the literature of current examples where electricity users have adopted various techniques to avoid going without electricity. There are numerous examples of electricity users participating in interruptible service agreements with utilities, operating self-generation equipment, shifting the timing of their electricity using activities as a part of time-of-use rate experiments, etc. These examples will be evaluated to show whether or not they offer users of electricity cost-effective alternatives to going without electricity. The evaluation will involve estimates of the amount of on-peak electricity demand ( $k W$ ) saved by the user from self-generation, load-management, etc.; the cost to the user of going without electricity, and issues relevant to the user for adopting the technique. 
To further explain our approach to this study, two issues related to the scope and definition of the study need to be clarified. One issue concerns how electricity users interact with the other participants in electricity markets including utilities, regulators and equipment manufacturers. Clarification of these interactions is necessary for the reader to fully appreciate the electricity user perspective. Analysis of the user perspective in isolation of the other groups would not be a realistic approach.

The second issue concerns the definition of the electricity supply constraint in terms of types, duration, frequency, warning, location and prices. The extent of user response is related to type of supply constraint. For example, user response would be limited if the supply constraint was limited to storm-related outages or random generation/transmission failure. Similariy, if fuel is in extremely short supply and the supply constraints were frequent and widespread (as is the case in many developing countries), significant responses including dramatic relocation could occur.

\subsection{THE ELECTRICITY SUPPLY CONSTRAINT DEFINITION}

The electricity supply constraint faced by users and its effect on how frequently users will be without electricity will determine the user response. Answering the following questions will define the supply-constraint scenario to be used for this study.

- Are the constraints to be capacity constrajnts or energy constraints?

- Are the constraints anticipated several years in advance so that investments can be made, or do the constraints appear without warning?

- Are the constraints relatively infrequent (0-15 times per year) or frequent (greater than 15 times per year)?

- Are the constraints less than six hours or greater than six hours in duration?

- Which areas of the country experience the supply constraint? 
- Do electricity prices increase in response to the supply constraints? If so, how are the increases passed along to consumers?

Table 1.1 provides a range of four types of electricity availability/ constraints. The first item listed, no outages, represents a situation that does not exist because it would be much too expensive to provide the redundant generation, transmission and distribution capacity necessary to guarantee no outages. The reason for showing this option is to provide a full range of alternative electricity availability/constraints.

Random outages, the second item on the list, represent the type of constraint (and electricity availability) currently faced by most electricity consumers across the U.S. Random outages occur infrequently and most often are caused by severe weather.

A capacity constraint refers to a situation where capacity is insufficient relative to peak-demand. This type of constraint is typically of short

\section{TABLE 1.1. Range of Four Types of Electricity Availability/Constraints}

\begin{tabular}{|c|c|c|c|c|c|c|}
\hline & & $\begin{array}{l}\text { Cause of } \\
\text { Outages }\end{array}$ & $\begin{array}{l}\text { Frequency } \\
\text { of Outages }\end{array}$ & $\begin{array}{c}\text { Duration } \\
\text { of Outages }\end{array}$ & $\begin{array}{c}\text { Electricity } \\
\text { Prlces }\end{array}$ & Comments \\
\hline & No outages & $\begin{array}{l}\text { electriclty } \\
\text { always } \\
\text { avallable }\end{array}$ & never & none & $\begin{array}{l}\text { much hlgher } \\
\text { then current } \\
\text { prlce levels } \\
\text { due to cost } \\
\text { of redundant } \\
\text { capacity }\end{array}$ & $\begin{array}{l}\text { This type of electriclty } \\
\text { avoliablilty is much too } \\
\text { costly to implement but } \\
\text { is included in this } \\
\text { chart for comparison } \\
\text { purposes. }\end{array}$ \\
\hline 2. & $\begin{array}{l}\text { Random } \\
\text { Outages }\end{array}$ & $\begin{array}{l}\text { storms, } \\
\text { random } \\
\text { system } \\
\text { fal lure }\end{array}$ & $2 /$ yeer & 1 hour & $\begin{array}{l}\text { current } \\
\text { price } \\
\text { levels }\end{array}$ & $\begin{array}{l}\text { This type of constraint } \\
\text { reflects current elec- } \\
\text { trleity avallability } \\
\text { levels. }\end{array}$ \\
\hline 3. & $\begin{array}{l}\text { Copacity } \\
\text { Constroints }\end{array}$ & $\begin{array}{l}\text { excessive } \\
\text { peak- } \\
\text { demand, } \\
\text { insufti- } \\
\text { clent peak } \\
\text { supply }\end{array}$ & $10-15 / \mathrm{yr}$ & 4-6 hours & $\begin{array}{l}\text { time-of-use } \\
\text { rates in } \\
\text { effect, } \\
\text { interrupt- } \\
\text { lole rate } \\
\text { options } \\
\text { avallable }\end{array}$ & $\begin{array}{l}\text { Th15 type of constralint } \\
\text { is currently confronted } \\
\text { by many users across the } \\
\text { U.S. today. }\end{array}$ \\
\hline 4. & $\begin{array}{l}\text { Energy } \\
\text { Constraints }\end{array}$ & $\begin{array}{l}\text { Insutfi- } \\
\text { clent } \\
\text { fuel or } \\
\text { bese load } \\
\text { supply }\end{array}$ & $\begin{array}{l}\text { several } \\
\text { per year }\end{array}$ & $\begin{array}{l}\text { weeks to } \\
\text { montns }\end{array}$ & $\begin{array}{l}\text { nigher over- } \\
\text { ali rates }\end{array}$ & $\begin{array}{l}\text { Thts type constralnt } \\
\text { occurs in developing in } \\
\text { developing countrles. }\end{array}$ \\
\hline
\end{tabular}


duration, accompanied by little warning and likely to occur at times of daily and seasonal peak demand. Consistent with PPA projections, this is the type of constraint relevant for this study.

An energy constraint refers to a situation where the amount of electricity (in $\mathrm{kWh}$ ) that would be purchased on average, over a specified time period, exceeds electricity supply over the same time period. This type of constraint generally results from insufficient fuel. Such constraints are generally of an extended duration, accompanied by a comparable warning period and have tended to occur in developing rather than industrialized countries.

\subsubsection{Type of Electricity Supply Constraint Selected for This Study}

For this study we assume that capacity constraints are the type of supply constraint experienced by electricity users, for several reasons. Based on historical experience in the U. S., capacity constraints are more common than energy constraints. Also, there are numerous examples to draw upon from recent experiences of individual utilities in California, Texas, Michigan, and Florida. Finally, capacity constraints are the type of constraint called for in the PPA projections (DOE 1983).

Next, consistent with PPA, NERC, and EPRI projections, we assume that the supply constraints occur in the mid-1990s. This also allows for consumers to have sufficient lead time to invest in new technologies and more energy efficient equipment. In addition, given the 10-year leadtime, utilities can take steps using the rate structure (such as time-of-use rates or interruptible rates) to minimize the capacity constraints. This is based on a survey of interruptable rate schedules offered by utilities in California and Texas that call for interruptions of up to 90 hours a year.

Because the constraints represent excess peak demand or insufficient peak supply, we assume that the constraints occur less than 15 times per year and to be less than six hours in duration. This assumption is consistent with current practice at electric utilities in the U.S. with capacity constraints. This is based on a survey of interruptible rate schedules offered by utilities in California and Texas that call for interruptions of up to 90 hours a year. 
Consistent with PPA projections, the constraints are expected to occur primarily in California, Texas and Florida. Utilities in these regions are expected to have relatively low reserve margins in the 1990's, increasing the likelihood for outages to occur.

We assume that electricity prices will increase steadily between now and 1995 in the form of time-of-use rates as a means of creating incentives for user responses to capacity constraints. This can be achieved if PUCs pursue pricing policies with the purpose of limiting peak demand. This is a reasonable assumption given current trends in regulation and 10 years of leadtime for PUCs to test time-of-use rate effectiveness.

Finally, we assume that electricity-users can experience the capacity constraints through:

- interruptions of power for the six-hour constraint period

- substantial time-of-use rate increases that go into effect for the six-hour constraint period

- both interruptions and time-of-use rate increases.

TABLE 1.2. Scope of Work for This Project

\begin{tabular}{|c|c|c|c|c|}
\hline & & Industrial & Comnerclal & Restidentiol \\
\hline 1. & Self-generation & $\begin{array}{c}\text { - cogeneration } \\
\text { - emergency } \\
\text { generation }\end{array}$ & cogeneration & low potential \\
\hline 2. & Fuel switching & $\begin{array}{l}\text { examples not } \\
\text { avallable }\end{array}$ & $\begin{array}{l}\text { examples not } \\
\text { avallable }\end{array}$ & $\begin{array}{l}\text { gas air condltioners, water } \\
\text { heaters, space heaters }\end{array}$ \\
\hline 3. & Relocation & $\begin{array}{l}\text { al uminum industry } \\
\text { In Paclific } \\
\text { Northwest }\end{array}$ & $\begin{array}{l}\text { examples not } \\
\text { avallable }\end{array}$ & exemples not avallable \\
\hline 4. & $\begin{array}{l}\text { Higher } \\
\text { Efficlency } \\
\text { Technologies }\end{array}$ & $\begin{array}{l}\text { hlgh efficlency } \\
\text { motors }\end{array}$ & $\begin{array}{l}\text { - energy manage- } \\
\text { ment systens } \\
\text { - thermal-storage }\end{array}$ & $\begin{array}{l}\text { - more efficlent appllances } \\
\text { - thermal-storege }\end{array}$ \\
\hline 5. & $\begin{array}{l}\text { Timing of } \\
\text { Activities }\end{array}$ & $\begin{array}{l}\text { response to } \\
\text { time-of-use rates }\end{array}$ & $\begin{array}{l}\text { response to } \\
\text { time-of-use rates }\end{array}$ & response to time-ot-use rates \\
\hline 6. & $\begin{array}{l}\text { Level of } \\
\text { Activities }\end{array}$ & $\begin{array}{l}\text { response to Inter- } \\
\text { ruptible rates }\end{array}$ & $\begin{array}{l}\text { response to Inter- } \\
\text { ruptible rates }\end{array}$ & $\begin{array}{l}\text { - response to interruptible rates } \\
\text { - direct control of alr condi- } \\
\text { tloners, water heaters, space } \\
\text { heating }\end{array}$ \\
\hline
\end{tabular}




\subsection{SCOPE AND LIMITATIONS}

Table 1.2 summarizes the scope of work for this project. On the top row of the table are the three relevant sectors of the economy: residential, commercial and industrial. On the first column are the six user response areas that have been identified. In the "cells" are relevant examples of user responses for which ifterature will be collected and case study analyses will be performed.

The empty cells in Table 1.2 indicate that examples are scarce or the potential is too low to warrant further analysis. For instance, there are no documented cases of residential or commercial customers relocating or threatening to relocate due to electricity capacity constraints that are limited to peak periods. Although scattered examples of self-generation for residential consumers exist, the potential is too low and uncertain (especially for peakperiod electricity capacity constraints) to warrant further analysis. Fuelswitching between oil and gas is common for industrial and some commercial electricity users. However, because of the costs, switching from electricity to gas or oil is not common. For some applications, like electric motors, fuel-switching from electricity to some other fuel is not practical unless the other fuel is used to self-generate electricity.

Given the project scope as outlined in Table 1.2, this report contains three chapters (which correspond to the three sectors), each with several subsections (which correspond to the response-areas). Each response-area subsection will contain information on:

- costs to users,

- users acceptance,

- technologies, and

- potential reductions in on-peak demand (in MW).

Some potentially important response areas are not considered due to the user-response rather than utility-response focus of this study. One of the major response-areas that was omitted is small power production where users or third parties install generating capacity to sell to utilities. This differs from self-generation because the capacity is added primarily for outside sale rather than onsite use. 


\subsection{REFERENCES}

Berman, I. M. 1983. "New Generating Capacity: When, Where and by Whom." Power Engineering. 87(4):50-58.

Cavanaugh, H. A. 1985. "Capacity Additions: How Much? How Soon?" Electrical World. January 1985.

EPRI. 1978. Costs and Benefits of Over/Under Capacity in Electric Power System Planning. Electric Power Research Institute, Palo Alto, California.

EPRI. 1985. Electricity Outlook: The foundation for EPRI R\&D Planning. Electric Power Research Institute, Pato Alto, California.

Navarro, P. 1985. The Dimming of America: The Real Costs of Electric Utility Regulatory Failure. Ballinger Publishing Co., Cambridge, Massachusetts.

NERC. 1981. Electric Power Supply and Demand 1982-1991. North American Electric Reliability Council, Princeton, New Jersey.

0TA. 1986. New Electric Power Technologies: Problems and Prospects for the 1990's. OTA-E-246, Office of Technology Assessment, Washington D.C.

U.S. DOE. 1983. Report of the Electricity Policy Project. DDE/PE-D045, Department of Energy, Washington D.C. 


\subsection{COSTS OF POWER OUTAGES TO ELECTRICITY USERS}

In evaluating what responses electricity users are likely to adopt in the event of electricity supply constraints, it is necessary to identify costs that consumers are likely to incur in the event of outages. If the costs are high, then users may be likely to adopt elaborate measures such as self-generation to mitigate the effects of outages. If the costs are low or nonexistent, then users will be less likely to adopt expensive or inconvenient responses.

There exists a substantial literature on the costs of outages to electricity users. Most of these studies have been conducted by utilities to address the issue of the costs of system under-capacity and over-capacity. The purpose of this chapter is to address the cost of outages by reviewing the literature so as to answer questions as to the types, nature, and levels of costs faced by users.

\subsection{OUTAGE COSTS}

The costs to users caused by outages or electricity supply constraints depend on the activities of the user that are impacted, the nature of and degree to which the impacted activities are dependent upon electricity, the availability of alternative energy sources (back-up generation, etc.), and the user's ability to resume the activity immediately after a service disruption and to reschedule activities impacted by outages to nonoutage periods. From a user's point of view, the key determinants of costs from supply disruptions are: time of occurrence, length, warning time, and frequency.

\subsubsection{Determinants of Outage Costs}

The time of day, day of the week, and season of the year, that an outage occurs can have a dramatic effect on the costs incurred by users. If the outage occurs during a period of peak consumption, as is assumed in our supply constraint scenario, then the costs will be high. Outages that occur during periods of high product demand will have higher costs to industry than those occurring during periods of slack production demand, and outages that occur 
during very hot days when residential and commercial users place a premium on air conditioning will probably cause higher costs than outages occurring on days of moderate temperature.

The duration and frequency of outages can have a substantial impact on the nature and magnitude of outage costs. Users will generally be better able to absorb the costs of outages that last a short time than costs of outages lasting a longer time, assuming both outages occur during periods of comparable consuming behavior.

On a per kWh basis, electricity disrupted may or may not have increasing costs as outage length increases. For some users longer outages may limit the ability to reschedule consuming activities to nonoutage periods. In other cases the first few minutes or hours of an outage may produce the greatest costs. This is true for industrial firms employing processes that are highiy dependent on continuous sources of electricity to prevent damage to equipment, and for firms that have computer and information processing equipment unprotected by back-up power sources. For some essential electricity uses, such as those for life support systems in hospitals and power for traffic signals, costs incurred for short duration outages can be astronomical, as human life may be placed in jeopardy.

The cost of outages is inversely related to the amount of preparation taken by users. If given enough warning, industrial firms may be able to shut off equipment in an orderly manner, avoiding equipment damage due to sudden drops in voltage. Firms may also be able to reschedule production to periods either before or after an outage period. Residential users may be able to avoid spoilage of food in refrigerators and freezers during an outage if they are given sufficient warning to plan meals in order to avoid buying ice. In our supply constraint scenario, we assume that little or no warning will be available before outages.

Frequency is an important factor to costs of service disruptions. If outages occur frequently or are perceived as being an ongoing phenomenon, users may take steps to mitigate the effects of service disruptions. In our scenario we assume that outages will occur 10 to 15 times per year. In the short run, users face only direct and ancillary effects of an outage. In the long run, 
users face the sum of the costs resulting from an outage plus the cost of measures taken to mitigate or lessen the effects of service disruptions.

\subsection{RESIDENTIAL SECTOR OUTAGE COSTS}

While outage costs can be estimated quite readily for the commercial and industrial sectors as the monetary costs of losses in production and equipment damage, outage costs for the residential sector are more difficult to measure. Since most activities in the residential sector are conducted without regard to market value it is more difficult to determine costs involved with disrupting these activities.

\subsubsection{Methods for Measuring Residential Outage Costs}

Several common methods were used in past attempts to measure the cost of residential outages. Studies conducted during the past ten years tried to determine the price a household would pay to avoid an outage. Many studies estimate these amounts by eliciting responses from a large survey sample in response to hypothetical outages. This technique was employed by Ontario Hydro in the late seventies in a number of studies as reported by Billinton et. al. (1982). Other studies have capitalized on relatively uncommon opportunities to survey residential households immediately following actual interruptions. An example of this is a study prepared by Fawcett Associates for EPRI in 1979, documenting the experience that occurred during a month of outages in Key West, Florida.

Another common approach used to measure residential outage costs involves classical welfare economics. This approach attempts to measure the loss of welfare resulting from diminishing user surpluses caused by drops in the availability of electricity. Demand curves are estimated for individual users for given time periods. The most common method for doing this has traditionally been through surveys of "willingness to pay". Users are asked, "how much would you pay for the first kWh, how much for the second, how much for the third, etc. ... within a period of $x$ hours?" Since users value certain electricity consuming functions over others, i.e. lighting over cooking, they will most likely respond with differing levels of willingness to fund each additional kWh for "nonessential" functions. 
Demand curves may also be estimated more directly based on information including hourly electricity consumption data, appliance use, and responses in consuming behavior to differing price structures (time of use rates, etc.). Such information is becoming increasingly available from research studies conducted by economists within utilities and in the academic community.

Another method based on the theory of labor/leisure tradeoff may be used to estimate the value of leisure activities impacted by outages. This method uses a household's wage rate to approximate the value of foregone leisure activities that use electricity. This method was employed in several studies conducted during the early 1970 s that focused on household activities impacted by outages such as TV viewing. This method ignores the existence of nonelectricity-using leisure substitutes for the electricity-using activities impacted. As an ancillary to this method, some studies, in particular one conducted by ORNL (Gilmer and Mack, 1982, 1983) have estimated upper bound outage estimates by attaching values to household activities based on wage rates for similar activities outside the home. They then estimated the costs of disruptions to specific functions such as household upkeep, and food preparation.

In general there are an array of issues guiding the choice between leisure/labor and user surplus-based methods for evaluating the cost of outages. A leisure/labor evaluation opens up questions of what is the appropriate wage level for a housewife. This method may also fail to differentiate between the timing of outages (hour, day and season), the amount of warning time and other parameters influencing outage severity and cost. User surplus-based methods may, on the other hand, distort the value of electricity used for preferred activities such as watching favorite TV shows.

No one methodology seems to best capture the issues of outage cost and value of service. In terms of ease, the wage rate method is probably the easiest. Wage rate information is readily available. Survey methods on the other hand, are likely to require greater resources and time, especially if very large samples are gathered. User surplus methods that do not use surveys to estimate demand curves probably fall somewhere in the middle. 


\subsubsection{Estimates of Residential Costs}

Within the wide variety of iiterature addressing the issue of costs to residential users arising from electricity supply constraints there is an even wider range of cost estimates. This variance is due to difference in estimation methodology, the application of different localities (many of the studies were conducted in other countries), the choice of assumptions made, and a wide range of socio-economic factors.

An extremely comprehensive survey of outage cost estimates was compiled by Sanghvi (1982). Table 2.1 reproduces the sum of his survey. Within these estimates costs range from 0 to $\$ 4.50$ per $\mathrm{kWh}$. Sanghvi further points out that upper and lower ranges for the cost of outages may be determined as the cost of backup generation and the cost of normal service respectively. Using this reasoning an upper bound estimate of $\$ 3$ and $\$ 5$ per kWh (1982 $\$$ ) was derived based on the cost of a $1.8 \mathrm{~kW}$ and $7 \mathrm{~kW}$ back-up diesel generator assuming approximately 60 hours of usage a year which is consistent with our assumptions of possible electricity supply constraints for the 1990's

(Sanghvi 1983).

Using a user surplus methodology to establish a lower bound for residential outage costs, Gilmer and Mack (1982) estimate the cost of outage durations of one and three hours for various appliances for different seasons of the year both peak and off peak. These estimates vary from $\$ 0.09$ per hour for clothes washing in the winter to $\$ 11.95$ per hour for refrigeration in the sumer. They further sum the outage cost estimates for all uses for one and three hour periods on a per kwh basis. Their estimates are summarized in Table 2.2. They further estimate upper bound cost estimates based on the value of production in the home. Using this method they estimate costs at $\$ 0.39$ to $\$ 1.30$ per $\mathrm{kWh}$. Using a user surplus methodology based on a market approach, Sanghvi, in later work (1983), estimates the cost of an outage as $\$ 0.13$ to $\$ 0.58$ per $\mathrm{kWh}$ depending on time of day and duration.

Using a survey willingness-to-pay method, Billinton et al. (1982) estimated that the cost of outages for residential users was $\$ 0.06 / \mathrm{kW}$ for outages of twenty minutes, $\$ 0.31 / \mathrm{kW}$ for outages of an hour and $\$ 3.16 / \mathrm{kW}$ for outages of four hours. 
TABLE 2.1. Costs of Outages to Residential Sector Users

\begin{tabular}{|c|c|c|c|}
\hline Study (Year) & Scope & Method & $\begin{array}{c}\text { Outage Cost } \\
\text { Estimate } \\
(1981 \$ / \mathrm{kWh}) \\
\end{array}$ \\
\hline $\begin{array}{l}\text { Sheppard/Electricity } \\
\text { Counci1, London (1965) }\end{array}$ & UK & Lost leisure at wage rate & 1.01 \\
\hline Lundberg, Jonnien & (a) UK & Lost leisure at wage rate & $1.51-4.54$ \\
\hline Orson/UNIPEDE & (b) Sweden & Survey & 1.54 \\
\hline $\begin{array}{l}\text { Turner/New Zealand } \\
\text { Electricity (1977) }\end{array}$ & New Zealand & Wage Rate & 0.50 \\
\hline $\begin{array}{l}\text { Ontario Hydro } \\
(1979)\end{array}$ & $\begin{array}{l}\text { Ontario Hydro } \\
\text { service ared }\end{array}$ & $\begin{array}{l}\text { Survey of willingness } \\
\text { to pay }\end{array}$ & $\begin{aligned} 20 \mathrm{~min} & =0.15 \\
1 \mathrm{~h} & =0.05 \\
4 \mathrm{~h} & =0.02 \\
7 \mathrm{~h} & =0.01\end{aligned}$ \\
\hline $\begin{array}{l}\text { Finnish Power } \\
\text { Producer's Council, } \\
\text { Finland (1978-79) }\end{array}$ & Finland & $\begin{array}{l}\text { Survey of willingness } \\
\text { to pay }\end{array}$ & $\begin{aligned} 15 \mathrm{~min} & =2.84 \\
1 \mathrm{~h} & =1.42 \\
4 \mathrm{~h} & =0.93 \\
10 \mathrm{~h} & =0.75\end{aligned}$ \\
\hline $\begin{array}{l}\text { Samsa, Hut and Krohm/ } \\
\text { Argonne (1978) }\end{array}$ & Illinois & $\begin{array}{l}\text { Use response following } \\
\text { winter outage that } \\
\text { lasted several days }\end{array}$ & 1.25 \\
\hline \multirow[t]{2}{*}{ Yabroff/SRI } & USA & $\begin{array}{l}\text { Lower bound: willingness } \\
\text { to pay }\end{array}$ & $2.09-3.51$ \\
\hline & & Upper bound: wage rate & \\
\hline Fawcett (1979) & $\begin{array}{l}\text { Key West, } \\
\text { Florida }\end{array}$ & $\begin{array}{l}\text { Survey following outage } \\
\text { of several weeks }\end{array}$ & $0.05-0.06$ \\
\hline Systems Control (1980) & $\begin{array}{l}\text { Jacksonville, } \\
\text { Florida }\end{array}$ & $\begin{array}{l}\text { Survey following an } \\
\text { outage }\end{array}$ & 0.00 \\
\hline $\begin{array}{l}\text { Sanghvi/Mathtech/ICF } \\
\text { (1982) }\end{array}$ & $\begin{array}{l}\text { Wisconsin, } \\
\text { weekday in } \\
\text { summer }\end{array}$ & $\begin{array}{l}\text { Willingness to pay to } \\
\text { avoid the cost of incon- } \\
\text { venience for one leisure } \\
\text { how measured by users' } \\
\text { surplus }\end{array}$ & $\begin{array}{l}\text { Outage } \\
\text { Duration } \\
1 h=0.18 \\
2 h=0.19 \\
4 h=0.22 \\
8 h=0.29\end{array}$ \\
\hline
\end{tabular}

Source: Sanghvi 1982. 
TABLE 2.2. Cost of Outages of 1 and 3 Hours Duration for Residential Electricity Users Estimated by Gilmer and Mack ( $\$ / \mathrm{kWh})$

\begin{tabular}{|c|c|c|c|c|c|c|c|c|}
\hline & \multicolumn{2}{|c|}{ Winter } & \multicolumn{2}{|c|}{ Spring } & \multicolumn{2}{|c|}{ Summer } & \multicolumn{2}{|c|}{ Fall } \\
\hline & Peak & $\begin{array}{l}\text { Off } \\
\text { Peak }\end{array}$ & Peak & $\begin{array}{r}\text { Off } \\
\text { Peak } \\
\end{array}$ & Peak & $\begin{array}{r}\text { Off } \\
\text { Peak }\end{array}$ & Peak & $\begin{array}{r}\text { Off } \\
\text { Peak } \\
\end{array}$ \\
\hline 1 hour outage & 0.131 & 0.126 & 0.155 & 0.161 & 0.161 & 0.171 & 0.158 & 0.153 \\
\hline 3 hour outage & 0.393 & 0.378 & 0.465 & 0.483 & 0.483 & 0.513 & 0.474 & 0.459 \\
\hline
\end{tabular}

Source: Gilmer and Mack 1982.

Based on the two studies surveyed by Sanghvi (Fawcett 1979 and Systems Control 1980) that address outage costs directly following outages, it seems reasonable that costs to residential users are significantly less than $\$ 1$ per $k$ Wh. This conclusion is reinforced by the findings of Sanghvi et al. (1980) that place the cost of outages at between $\$ 0.18$ and $\$ 0.29$ per hour depending on duration. The higher costs per $k$ wh as duration increases seems logical as inconvenience for residential customers is sure to be a function of outage length.

\subsection{COMMERCIAL SECTOR OUTAGE COSTS}

Many of the same techniques used to measure costs of outages in the residential sector can be applied in the commercial sector. In the commercial sector much of the electricity consumed is for uses that are necessary to production and continuance of operation.

A significant difficulty with measuring comercial sector outage costs and value of service is the heterogeneity of this sector. Because of the vast variation in the types of establishments, it is very difficult to measure their individual valuations of service and outage costs without concentrating a considerable effort to study each type of operation. The electricity usage of a large office building is very different from that of a hospital.

\subsubsection{Methods for Measuring Commercial Sector Outage Costs}

In general the key activity of the comercial sector is the production of services. As much of this production is dependent upon the direct supply of 
electricity to provide necessary functions, it may be relatively easy to estimate the direct effects of an electricity outage in terms of lost revenue.

Because most firms are dependent on the supply of electricity as factor inputs, commercial firms may be able to more accurately define and estimate outage costs than the residential sector. Subsequently, survey methods of data collection relying on firms to identify their costs tend to hold more validity than they do in the residential sector. This has been the main method used to evaluate outage costs in the commercial sector. Still, commercial sector firms may have limited experience with outages and estimating the resulting costs.

Methods employing user surplus losses may effectively estimate commercial sector outage costs. As in the case of the residential sector, user surplus losses may be estimated either with surveys of willingness to pay to prevent outages or through market-based approaches.

Another method involves the use of losses in wages as a proxy for losses in production. This method is probably likely to underestimate the cost of outages, as it ignores exceptional components of cost, including damage to equipment and stock.

\subsubsection{Estimates of Costs of Outages to Commercial Users}

Costs of an outage in this sector will depend on a number of key factors, including the type of establishment, activities impacted, length, duration, and frequency of outage, preparation on the part of the firm such as the availability of backup generation, and the ability of the firm to resume activity after electricity service is restored and make up for lost production.

Some types of firms such as those that deal in the office service industries (insurance companies, economic consulting firms, etc.) may be able to resume production and make up for lost production fairly easily. These firms may have to pay overtime wage rates. Other enterprises such as restaurants may not be able to make up for lost sales. Supermarkets may experience damage to food during outages. Firms that use computers may experience high costs if systems go down resulting in losses of data and information. Hospitals and police stations may not be able to provide vital public services in the event of outages. Stores may face losses to theft and looting as electric lights and 
alarm systens are shut off. The loss of air conditioning can affect many businesses. In general, those firms that have a modest electricity demand but use the electricity to perform vital services for which there is no other energy substitute will face the highest costs.

A complete survey of outage cost estimates for commercial sector firms was undertaken by Sanghvi (1982). The results of his findings are sumnarized in Table 2.3. An interesting aspect of many of the estimates is the magnitude of the cost per kwh of service disrupted. Most estimates are on the order of $\$ 1$ to $\$ 15$ per $k$ Wh for outages of one hour in duration.

The high cost is probably due to several factors. First, the commercial sector is more electricity intensive than other sectors. Approximately $60 \%$ of commercial sector energy use is comprised of electricity. Secondly, while the commercial sector is not as energy intensive as the industrial sector in terms of energy use per dollar of value added, electric power does play a necessary role in production. A minor disruption in the supply of electricity for a short time can result in great expense to commercial users if production is halted. An example would be a restaurant that is forced to close for a period of even a few hours during dinner time due to an outage. Though the restaurant may have a demand of only a hundred kWh during those two hours, the losses in trade due to closing may equal several thousand dollars.

It appears uncertain whether the commercial sector on aggregate faces increasing or decreasing per $k$ Wh costs as outage duration increases. For many users, a large component of service disruption costs may be damage to equipment and materials experienced during the first minutes of an outage. Other users that are not facing high initial damage costs probably face increasing per kWh costs.

An estimate for outage costs to commercial sector firms could also be derived by estimating the cost of providing back-up generation. Some firms that recognize outages as an ongoing occurrence, might choose to install generating capacity if the cost was perceived to be less than the cost of expected outages. Self-generated electricity could be provided on a back-up basis for forty hours a year at a cost of approximately $\$ 0.50-\$ 1.00$ per kWh. This estimate was derived based on a quote for a $100 \mathrm{~kW}$ diesel generator of $\$ 26,700$ 
TABLE 2.3. Survey of Costs of Outages to Comnercial Sector Users

\begin{tabular}{|c|c|c|c|}
\hline Study (Year) & Scope & Method & $\begin{array}{c}\text { Outage Cost } \\
\text { Est imate } \\
\{1981 \$ / \mathrm{kWh}\}\end{array}$ \\
\hline $\begin{array}{l}\text { Sheppard, Electricity } \\
\text { Council (1965) }\end{array}$ & UK & Lost wages & $\$ 5.65$ \\
\hline \multirow[t]{3}{*}{$\begin{array}{l}\text { Patton et a1./IEEE } \\
(1975)\end{array}$} & USA & Survey & $\begin{array}{rl}1 & h=8.97-14.05 \\
>1 & h=16.61-52.07\end{array}$ \\
\hline & & & $\begin{array}{l}\text { Commercial } \\
\text { buildings } 12.21\end{array}$ \\
\hline & & & $\begin{array}{l}\text { Office buildings } \\
15.00\end{array}$ \\
\hline $\begin{array}{l}\text { Congressional Research } \\
\text { Service }(1977)\end{array}$ & NYC Blackout & $\begin{array}{l}\text { Survey - accounting } \\
\text { of component costs }\end{array}$ & $\begin{array}{l}4.99 \text { ( } 1.78 \text { economic } \\
\text { cost }+2.21 \text { social } \\
\text { cost })\end{array}$ \\
\hline SCI (1977) & NYC Blackout & Survey & $\begin{array}{l}5.56 \text { (direct costs } \\
0.90+\text { indirect } \\
\text { costs of } 4.65 \text { ) }\end{array}$ \\
\hline Ontario Hydro (1979) & Canada & Survey & $\begin{array}{lrr}\begin{array}{c}\text { Office } \\
\text { Building }\end{array} & \begin{array}{r}\text { Retail } \\
\text { Trade }\end{array} \\
1 \mathrm{~min} & 217.80 & 28.8 \\
1 \mathrm{~h} & 14.50 & 7.87 \\
4 \mathrm{~h} & 12.70 & 9.98 \\
8 \mathrm{~h} & 11.34 & 16.37\end{array}$ \\
\hline Yabroff/SRI (1980) & Northeast USA & $\begin{array}{l}\mathrm{Clean-up} \text { and loss } \\
\text { of wages, damaged } \\
\text { goods, etc. }\end{array}$ & $1.47-3.48$ \\
\hline
\end{tabular}

Source: Sanghvi 1982.

including switching apparatus and installation, a 20 year life time, diesel fuel at $\$ 1.00$ a gallon, and a $10 \%$ discount rate. (a) This estimated cost is considerably less than almost all of the outages costs reviewed in our survey. Firms may however not be willing to invest in generation equipment under any circumstances. Our cost estimate, is based on a twenty year lifetime.

(a) Quote from Curtis Generator and Equipment Inc., Baitimore, MD. 
Many firms may not base their planning decisions on as long a time-frame. Also many firms may either not be able to accurately estimate their outage costs or may not accept supply constraints as a permanent occurrence. Lastly, many commercial firms may be reluctant to take on proprietorship responsibilities with any form of mechanical equipment.

\subsection{INDUSTRIAL SECTOR OUTAGE COSTS}

Probably more than the other sectors, industrial sector firms are able to correctly identify and estimate costs incurred due to outages. For almost all firms, electricity is a necessary factor input into production. A curtailment. or disruption in electricity supplies therefore leads to losses in output.

Outage costs for the industrial sector include losses in production, damage to stock and equipment, restart-up costs, losses of wages, and safety and health effects. The industrial sector is also very heterogeneous. For firms in some industries, the costs of outages will be very slight, resulting in losses in production that can be made up in slack periods. For firms in other industries, outages of only a few minutes in duration can result in equipment damage of tens of thousands of dollars.

The level of costs incurred by industrial sector firms will generally decrease as the amount of warning time before an outage increases. Firms may be able to nearly eliminate damage costs if they are able to halt production in an orderly manner. Even so, some firms that have high start-up costs such as those in the chemical and petroleum industries may not be able to limit their exposure to outage costs as easily.

\subsubsection{Methods for Estimating Industrial Sector Outage Costs}

Because industrial sector firms are dependent on electricity for production and are able to identify the costs of losses in production, the chief method for evaluating industrial outage costs has been through the use of surveys. By questioning key industry officials and plant engineers, past researchers have been able to evaluate expenses such as damage to equipment and stock, extra maintenance and repajr costs and losses in production that cannot be made up. 
Another approach to measuring industrial sector outage costs relies on a firm's production function. This function is a mathematical representation of the relationships between output and input factors to production such as capital, labor, energy, raw materials, etc. Changes therefore in the availability of one or more input are evaluated by the resulting changes in output. The simplest functional form used to estimate outage costs has output related as a linear function of $\mathrm{kWh}$ consumed. Sanghvi (1982) cites several early studies employing this method. Often output is measured as GNP or value added. More rigorous analysis may be conducted through the derivation of demand curves on a firm by firn or industry basis.

\subsubsection{Estimates of Industrial Sector Outage Costs}

Estimates of the costs of outages to the industrial sector vary considerably due to the methodologies used to generate the estimates, the geographic location of the study population, and assumptions of outage duration, frequency and severity. In addition, estimates can vary due to the specific industries represented within individual studies and due to the heterogeneity of the industrial sector.

Table 2.4 presents a sumary of estimates gathered by Sanghvi. An interesting feature of many of the outage cost estimates presented here is the declining cost per $\mathrm{kWh}$ as outage duration increases. This probably reflects a large autonomous component of industrial sector outage costs due to material and equipment damage and start-up costs.

Using an involved survey process, Devine and Boyd (1981) estimated the cost to the Tennessee Valley Authority region as a whole for outages to industrial manufacturers. Though they reported a wide range of estimates for differing outage periods, the average cost is estimated to be $\$ 3.24$ per kwh for outages of one hour occurring once per year, and $\$ 1.20$ per kth for outages of 3 hours also occurring once per year. A good deal of their analysis is focused on identifying the cost of mitigating the cost of outages. They identify the upper bound cost of outages that occur with regularity as the cost of effective back-up generation. Subsequently, they have estimated the cost for outages occurring ten times per year are less expensive than outages occurring once a 
TABLE 2.4. Summary of Outage costs to Industrial Sector Firms

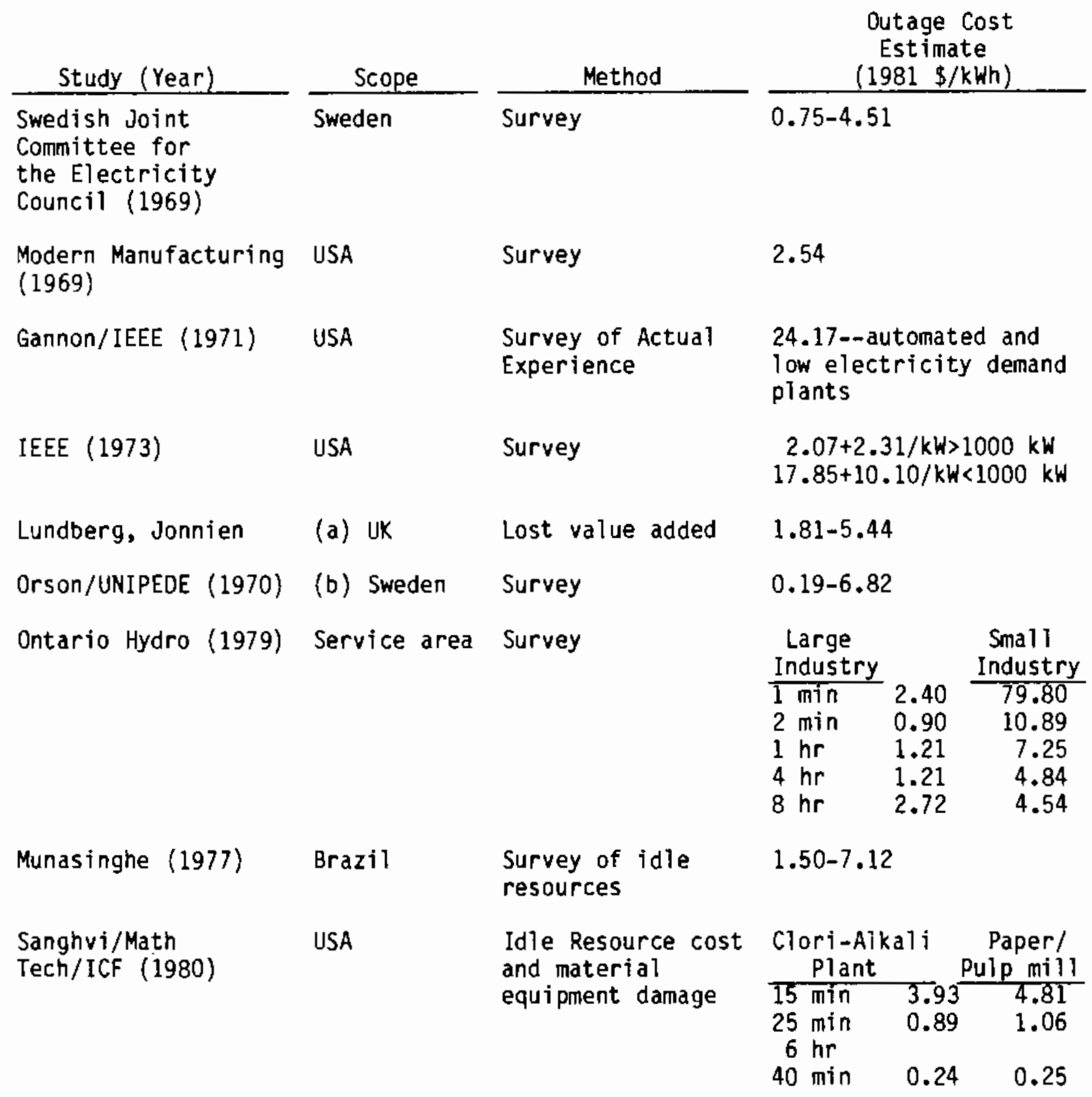

Source: Sanghvi 1982.

year. Their estimate for the average cost outages occurring with this frequency is $\$ 0.45$ per $k$ wh for one hour outages, and $\$ 0.26$ per $k$ wh for three hour outages. 
In a paper presented to the Canadian Electrical Association, Billinton et a1. (1982) discuss the results of a number of surveys conducted by several utilities and Canadian Universities that assess the various costs to users of electricity supply interruptions. An interesting aspect of their work involves the results of survey questions oriented at identifying the relationship between the cost of outages and the existence of advance warning before outages. Of the industrial users surveyed, $75 \%$ responded that they would be able to make cost saving arrangements if they were given advance warning. Among large users (those within heavy industry), a slightly smaller 73\% responded that they would be able to make cost saving arrangements. Among those that responded positively, a $68 \%$ average outage cost saving was reported for industrial firms contingent upon three days warning, with a $32 \%$ reduction for large users.

In Section 4.0 of this paper, we derive an estimate of the cost of providing back-up generation of $\$ 0.38$ per $\mathrm{kWh}$. This estimate is based on the installation of a $35 \mathrm{MW}$ generator to be operated solely on a back-up bas is consistent with our supply constraint scenario (40-60 hours per year). This cost is considerably lower than any of the cost estimates presented in any of the studies we surveyed. This indicates that rational firms aware that they are facing a series of outages that are expected to continue in the future, might invest in back up generation equipment rather than face the much higher unmitigated costs of outages.

\subsection{SUMMARY OF FINOINGS}

In general, there is a tremendous variation in estimated outage costs within each of the three end use sectors. Outage cost estimates often vary by as much as an order of magnitude. Much of this variation seems to be based on differences in estimation methodology, the sample population studied, and the assumptions pertaining to outage characteristics.

Key determinants of outage cost include the time of occurrence, activities impacted, duration, and amount of warning time given. Changes in these attributes substantially alter the costs to end-users. Cost estimates for our 
supply constraint scenario, would perhaps not be as applicable if changes were made in key assumptions about outage frequency, duration, and warning time.

Within the residential sector the most reasonable estimates of outage cost seem to be on the order of $\$ 0.05-\$ 0.50$ per $\mathrm{kWh}$ for outages of the type called for in our scenario. Overall estimates range from $\$ 0.0$ to $\$ 5.00$ per $k$ Wh. Above and beyond this cost there may be exceptional costs to some users resulting from damage to appliances or disruptions of key leisure activities. The residential sector may be characterized as having increasing costs per kWh curtailed as the duration of the outages increases.

The highest costs per kWh were reported for the comercial sector. Outage cost estimates ranged between $\$ 1$ and $\$ 20$ per $k W h$, with most clustered between $\$ 5$ and $\$ 10$. A reasonable estimate for our scenario would be $\$ 1$ to $\$ 5$ per kWh. This is probably due to the relatively essential role played by electricity as a factor input to production. Because of the extreme heterogeneity of the commercial sector and comercial sector electricity using behavior, there are wide variations in the types and magnitude of costs associated with outages. For many users there definitely exists an inverse relationship between outage duration and cost per $k W h$ for supply disruptions of the same magnitude of our supply constraints scenario.

The industrial sector is also very heterogeneous, and outage costs vary considerably among classes of end users. Estimates for outage costs range between $\$ 0.50$ and $\$ 10$ per $\mathrm{kWh}$ for outages of several hours duration. A reasonable estimate for outage called for in our supply constraints scenario would \$1-\$3 per kwh. Actual outage costs will vary according to the type of firm. Anong the industrial sector, there exist a number of electricity using industries that are extremely sensitive to drops in voltage or electricity supply. These industries which include aluminum and glass producers face very high outage costs (Adams et al. 1983). For many firms the main outage component is the opportunity cost of lost production. The level of costs incurred for these firms will depend on their ability to reschedule lost production to nonsupply constraint periods.

Most of the studies we surveyed estimated outage costs on a per kwh basis. The principle reason that these studies were conducted in this manner 
is that most end-users are probably more comfortable viewing electricity in this manner. For them, an outage has two main dimensions, the amount of power curtailed and the length of the disruption.

As this study deals with evaluating end user responses to electricity supply constraints caused by insufficient peaking capacity, it is perhaps useful for estimates of the cost of outages to be presented on a $\mathrm{kW}$ or capacity basis as well. This allows readers to address the issue of what the worth would be to an end-user of an additional $\mathrm{kW}$ of peak generating capacity that would increase availability and therefor prevent a portion of supply disruption induced outages. An assumption is made here that the value of a $\mathrm{kW}$ of marginal generating capacity is equivalent to the cost to end-users of any outages that it prevents.

To derive estimates of outage costs on a per $\mathrm{kW}$ basis, we used the most reasonable estimates of the costs per kWh for each sector and multiplied these estimates by 40 , the lower bound of the number of hours of outages expected each year under our electricity supply constraints scenario. Lifecycle valuations were then developed over a 30 year period (the assumed life time for utility peaking capacity equipment) and a discount rate of $10 \%$.

For the residential sector per $k$ hh cost estimates of $\$ 0.05-\$ 0.50$ yield per $\mathrm{kW}$ lifecycle costs of $\$ 21-\$ 210$. For the commercial sector the cost estimates of \$1-\$5 per kWh translate into costs of $\$ 415-\$ 2074$. Industrial sector cost estimates of outage costs of $\$ 1-\$ 3$ per $k$ Wh indicate per $k W$ costs of $\$ 415-\$ 1245$.

\subsection{REFERENCES}

Adans, R. C. et al. 1983. The Oirect Service Industries: Their Contribution to the Northwest Power System and Economy. Prepared for Direct Service Industries by Battelle's Pacific Northwest Laboratories, Richland, Washington.

Billinton, R., et a1. 1982. "Customer Oamage Resulting from Electrical Service Interruptions." Presented to the Canadian Electrical Association, Spring, 1982. 
Congressional Research Service. 1979. Are the Electric Utilities Gold Plated? A Perspective on Electric UtiTity Reliability. Subcomittee on Energy and Power, Committee on Interstate and Foreign Commerce, U. S. House of Representatives, Washington, D.C.

Devine, W. D. and D. A. Boyd. 1981. Costs of Electric Power Outages to Manufacturers. ORAU/IEA-81-9. Institute for Energy Analys is, Oakridge, Tennessee.

Jack Fawcett Associates. 1979. Power Shortage Costs and Efforts to Minimize: An Example. EPRI EA-124T. Electric Power Research Institute, Palo Alto, California.

Resource Consulting Group, Inc. 1981. The Cost of Electrical Supply Interruptions. Washington, D.C.

Gilmer, R. W. and R. S. Mack. 1983. "The Cost of Residential Power Outages." The Energy Journal, Vol. 4, No. 3.

Gilmer, R. W. and R. S. Mack. 1982. The Cost of Electric Power Interruptions to Residences in the Tennessee Valley. ORAU/IEA-82-4. Institute for Energy Analysis, Oakridge, Tennessee.

Mathtech Inc. and ICF Inc. 1982. Environmental and Socio-Economic Consequences of a Shortage in Installed Generating Capacity. EPRI EA 2462. Electricity Research Institute, PaTo Alto, California.

Samsa, M. E. K. A. Hut, and G. C. Krohm. 1978. Electrical Service Reliability: The Customer Perspective. ANL/AA-18. Argonne National Laboratory, Argonne, Illinois.

Sanghvi, A. P., R. Levy, and J. Wharton. 1985. "Planning Demand-Management Programs Based Upon Customers' Perceived Value." IEEE, 85 WM 072-4. Presented at the IEEE/PES Winter Meeting, February, 1985.

Sanghvi, A. P. 1983. "Household Welfare Loss Due to Electricity Supply Disruptions." The Energy Journal, Vol. 4, No. 3.

Sanghvi, A. P. 1982. "Economic Costs of Electricity Supply Interruption: U.S. and Foreign Experience." Energy Economics, Vol. 4, No. 3.

Shaw, W. B. 1977. "Costs of Inadequate Capacity in the Electric Utility Industry." Energy Systems and Policy. Vol. 2, No. 1.

Stanford Research Institute. 198D. The Worth of Electricity to Consumers: A Model Structure. Menlo Park, California. 
Stanford Research Institute. 1976. Impacts from a Decrease in Electric Power Service Reliability. Menlo Park, California

U.S. DOE. 1981. The National Reliability Study: Final Report. D0E/EP-0004, Department of Energy, Washington, O.C. 


\section{3.n RESIDENTIAL SECTOR RESPONSE TO ELECTRICITY SUPPLY CONSTRAINTS}

In 1983 residential customers consumed 751 billion kilowatt hours (kWh) of electricity or about $35 \%$ of the electricity demand in the United States. Much of this demand was used to meet the substantial electric power requirements of residential appliances and space conditioning equipment. Table 3.1 shows that electricity is the predominant power source for these appliances.

To analyze the potential for residential response to electricity supply constraints, five possible response areas were identified. The areas were conservation practices, which may include more efficient electricity use and comfort level changes, fuel switching, thermal storage, direct load control of space conditioning and water heating equipment and alternative rate structures.

IABLE 3.1. Residential Fuel Consumption by End-Use in 1980 (Quads) (a)

\begin{tabular}{|c|c|c|c|c|}
\hline End Use & Electricity & Gas & 011 & Other \\
\hline Heat/Cool Systems $(b)$ & 2.18 & 3.36 & 1.96 & 0.49 \\
\hline Refrigerator & 1.33 & 0 & 0 & 0 \\
\hline Water Heater & 1.30 & 8.5 & 0.13 & 0.16 \\
\hline Lighting & 0.99 & 0 & 0 & 0 \\
\hline Range & 0.51 & 0.31 & 0.04 & 0 \\
\hline Oryer & 0.44 & 0.08 & 0 & 0 \\
\hline Freezer & 0.44 & 0 & 0 & 0 \\
\hline Room Air Conditioner & 0.40 & 0 & 0 & 0 \\
\hline Other $(c)$ & 0.55 & 0.45 & 0 & 0 \\
\hline Total & 8.14 & 12.7 & 2.13 & 0.55 \\
\hline
\end{tabular}

Source: Department of Energy, Supplement to March 1982 Consumer Products Efficiency Standards Engineering and Economic Analys is, DOE/CE-0045 p. 57.

(a) A quad is 1015 British Thermal Units.

(b) Includes central space heating, room space heater, central air conditioner and heat pump.

(c) Includes washer, dishwashers, disposals, television, radio, portable appliances, etc. 
To evaluate the potential for response, several case studies were selected and reviewed in each response area. For each case study this report describes the location, geographic coverage, the study method, the results estimated in peak $\mathrm{kW}$ demand reduction and customer acceptance of the program. These estimates are based upon the individual case studies and the EIA residential energy consumption survey.

\subsection{RESIDENTIAL ELECTRICITY CONSUMPTION 1985-1995}

For the past several years, electricity consumption per household has been declining. This trend, however, has been partially offset by an increase in the number of new households that are using electricity as well as an increase in older households that are adding or converting to electrical appliances or space conditioning equipment. Based upon these trends and the U.S. Bureau of Census projections of population growth, electricity demand should increase at an annual rate of 2.5\% into the mid 1990's (DOE 1983; DOE 1984a), while the consumption of natural gas and fuel oil are expected to decrease. Given this fact, demand in 1990 will be 882 billion kWh, 12.5\% over 1985 levels and 1005 billion kWh in 1995, an increase of 28\% from 1985 (D0E 1984a).

\subsubsection{Residential Sector Peak Demand}

The peak-period electric power requirements of residential electricity users are quite significant. Of these, space-conditioning and water heating play a leading role. Table 3.2 shows the peak demand for typical 1980 residential electric uses during the summer peak period from 4 to $6 \mathrm{p.m}$. To illustrate the importance of space conditioning to peak demand, the Public Service Company of 0klahoma estimated that on their system's peak day (July 2D, 1984), residential air conditioning comprised $39.33 \%$ of the total system demand.

Estimates of residential peak demand in 1990 and 1995 use projections of an annual nationwide load factor and average electricity demand. Load factor is the ratio of peak demand to average demand and can take on a value between zero and one. In the residential sector, this vaiue is typically low as residential demand fluctuates on an hourty and seasonal basis causing peak demand to be significantiy higher than average demand. Average demand is derived by dividing total electricity consumption by 8760 , the number of hours in a year. 
TABLE 3.2. Peak Demand of Typical 1980 Electrical Appliances During the Summer Peak Period $(4-6$ p.m.)

\begin{tabular}{lcccc} 
Central air conditioning & $\begin{array}{c}\text { Average } \\
\text { kW per } \\
\text { Unit }\end{array}$ & $\begin{array}{c}\text { Tota } \\
\text { Stock } \\
\left(10^{6}\right)\end{array}$ & $\begin{array}{c}\text { Total Nationa } \\
\text { Peak Demand }\end{array}$ \\
\cline { 2 - 3 } Room air conditioning & 4.31 & & 24 & 103 \\
Water heater & 1.29 & 24 & 31 \\
Refrigerator & 0.58 & 28 & 16 \\
Freezer & 0.23 & 84 & 19 \\
Range & 0.18 & 37 & 7 \\
Dryer & 0.35 & 41 & 14 \\
Lighting & 0.15 & 32 & 5
\end{tabular}

(a) Based on the ORNL Residential Energy End IJse Model and Bureau of Census data.

(b) The total peak demand will not occur at the same time of day because of varying weather conditions and different time zones throughout the country.

Given a load factor of 0.62 (DOE 1983) and average demand of 85.73 GW in 1983, peak demand in 1983 is 138.27 GW. Assuming that load factor remains constant throughout the projection period and an annual growth rate in electrical demand of 2.5\%, residential peak demand estimates for 1990 and 1995 are derived. These figures are contained in Table 3.3 .

\section{TABLE 3.3. Estimated Residential Average and Peak} Electric Demand, GW

$\begin{array}{cccc}\frac{\text { Year }}{1990} & \text { Average Demand } & & \text { Peak Demand } \\ 1995 & 100.68 & & 162.39 \\ 114.73 & & 185.04\end{array}$




\subsection{SHIFTING THE TIMING OF ELECTRICITY USE IN RESPONSE TO ELECTRICITY SUPPLY CONSTRAINTS}

Electricity rates provide three fundamental signals to the consumer:

1) rates influence the consumer's daily pattern of electrical consumption; 2) rates provide signals as to the availability of electricity; and 3) rates will have an influence on the consumer's choice of energy-using equipment and appliances.

Rate structures can be (and are) used hy utilities to ration capacity. They are, therefore, somewhat outside of the domain of this study. However, the consumer may sign up for an alternative rate structure if he/she believes the alternative rate structure will leave him/her better off (i.e., save money). Alternative rate structures such as time-of-use rates do affect the timing of electricity use by providing monetary incentives for consumers to alter their behavior and by providing an inducement to alter the stock of appliances.

\subsubsection{Background}

Faced with future electricity capacity constraints, a number of utilities in Europe and America have experimented with or implemented time-of-use (TOU) rate structures. Among these rate structures are of $f$-peak rates, interruptible rates, and seasonal rates, as described below:

- Time-of-use rates--rates where higher costs are charged for power during a utility's peak period and lower costs during of f-peak periods.

- Off-peak rates--rates priced to reflect lower off-peak costs that the customer may chose to take advantage of for specific end uses such as for operating a heat storage or hot water storage system.

- Seasonal rates--rates where the season in which the utility reaches its peak has a higher flat rate than other seasons.

- Variable levels of service--rates where customers subscribe to a minimum electric service consistent with their needs--e.g., interruptible rates. 
Essentially, peak load pricing of electricity means selling electricity under a rate structure that reflects the pattern of variation in the marginal cost of supplying electricity at any point in time. The marginal cost of supplying electricity is the ratio of the incremental cost to total system cost of producing and delivering an additional unit of output (in $\mathrm{kW}$ ). For example, if it costs more to produce an additional $100 \mathrm{MW}$ of electricity because a more expensive source is used, the added cost is passed on to the user. By setting price equal to marginal cost, consumption will be encouraged when consumers value the use of the electricity above the added costs charged for producing it and discouraged whenever the costs of producing an additional unit of electricity exceed the added benefits to the consumer.

Residential Tol rates have been offered primarily on a volunteer basis. The consumer will only opt for the Tou rate if he/she believes they will save money. On the other hand, if Tou rates are mandatory the consumer's behavior may be vastly different.

If the Tou rates are pemanent, consumers have a greater incentive to change their appliance stock in the long run. For example, consumers will be more willing to replace their regular water heater with a themal storage heater that would only operate during the lower priced off-peak hours. Consumers will not make long-term adjustments in their lifestyles untess they feel the rate structure is permanent.

\subsubsection{Case Studies}

3.2.2.1 France

Electricity in France is generated and distributed by Electricity' de France (EdF), a single nationally owned utility that has the authority to establish electricity tariffs. Roughly two-thirds of the utility's generating capacity is composed of thermal units, with the remaining one-third being hydroelectric. EdF is a winter-peaking system with two distinct daily peaks at about 8 a.m. and 5 p.m.

By the early 1950s, it had become apparent to company officials that the electrical system was becoming severely constrained by total available and 
planned generating capacity. Responding to this problem, Edf offered rates to high-voltage customers on an optional basis in 1958, and to residential and agricultural customers in 1965.

Residential customers were offered one of two rate structures to choose from: a TOU rate or a subscribed demand rate. Under the subscribed demand option a fuse or circuit-breaker charge is levied, which increases with the maximum current rating of the customer's service regardless of time of use.

Because the installation or change of master fuses can only be done by the utility, Edf retains control of the customer's maximum demand. The consumer still pays a standard tariff per $k$ hh.

The TOU rate allows customers to obtain off-peak energy between the hours of $10 \mathrm{p.m}$. and $6 \mathrm{a} . \mathrm{m}$. at about one-half the standard rate by increasing their monthly fixed payments to cover the additional costs of the day/night meter. As of 1977, nearly 2.7 million residential customers had signed up for the TOU rate. EdF found that those most willing to use this structure had both storage space heaters and water heaters and a total monthly consumption of at least $800 \mathrm{kWh}$.

The TOu structure had become so successful in encouraging off-peak loads that local peaks were beginning to occur at times considered to be the off-peak hours. Responding to this potential problem, EdF implemented clock controls and remote telecontrol methods to stagger switch-on times of storage-heating devices.

Although no estimates are available on the effect of the residential rates on the system peak, it is estimated that, including all sectors--residential, comprercial and industrial--these rate structures have resulted in a net reduction in the $8 \mathrm{a} \cdot \mathrm{m}$. system peak of $700 \mathrm{MW}$ in 1965 and $1400 \mathrm{MW}$ by 1975.

\subsubsection{England}

In 1966-67 the Electricity Council of London and six Area Boards in England and Wales commenced a large-scale experiment with alternative forms of rates for residential consumers. The experiment ran for five complete years and ended in 1972. The aim was to ascertain the effect of price on the demand 
for electricity. Samples of consumers were invited to pay for their electricity on one of three experimental rate structures: seasonal, seasonal time of day, or load rate.

Altogether, some 3420 customers took part in the experiment. In addition to the 2520 customers with experimental forms of charges, there was a control group of 900 customers on the standard tariffs.

The seasonal tariff had a higher kwh price, some $150 \%$ of the unrestricted rate of the ordinary tariff for the months of December, January and February. The sumner rate, which covered the remaining months, was about $70 \%$ of the standard tariff.

The seasonal time-of-day tariff had a higher kWh price, $300 \%$ of the standard, applied from 8 a.m. to I p.m. and again from 4:30 p.m. to 7:30 p.m.; i.e., 8 hours a day. A lower kWh price, $40 \%$ of the standard tariff, applied from 4 a.m. to 7 a.m. every day. Elsewhere, an intermediate price, $80 \%$ of the standard, was applied.

The load rate tariff allowed consumption below a certain setting, specific to each household, to have a fixed charge per $\mathrm{kW}$ per annum and a $\mathrm{kWh}$ price at $60 \%$ of the standard price. When the rate of consumption was above the setting, the kWh price rose to some 100 to $200 \%$ of the standard. The peak savings associated with this tariff were minimal. Those consumers who had storage-heating equipment did take advantage of the rate differential to smooth out their daily consumption. Both groups of customers on the Tou rates responded to the price signals provided by the tariffs in the expected directions. Under the seasonal tariff, customers reduced their consumption of electricity in both the summer and the winter. This was explained by the increase in use of storage-heating equipment from the experimental households. (a) since some heating is necessary during the summer, total consumption in the off-peak hours did increase.

Customers on the time-of-day tariff decreased their consumption during the peak hours and increased consumption during the night and off-peak hours. Both

(a) The use of thermal storage is discussed in a later section. 
rate structures were effective in discouraging peak-period consumption and increasing usage at off-peak periods.

To evaluate the potential benefits from the use of these rates, investigators relied on measuring the difference in benefits from consumers on the standard tariff to consumers on the TOU tariff. They concluded that when set against the additional metering and billing costs of the technology then avaitable, peak-load pricing for residential customers resulted in net losses to the economy, on average. However, a more recent study (Huettrer 1982) concluded that the British time-of-day tariff yielded positive net benefits if the rates were limited to large customers.

\subsubsection{Vermont}

In late 1974, the Vermont Public Service Board entered into a cooperative agreement with the Federal Energy Administration and contracted with Green Mountain Power Corporation to study six alternative rate structures ranging from interruptible rates to the standard rate structure. Twenty customers were chosen on a volunteer basis for each of the six rates, for a total of 120 test customers.

In the peak period from 7:00 a.m. through 9:00 p.m., the rate structure charged customers approximately twice the amount of the standard tariff. During the off peak hours the charge was $40 \%$ of the standard.

The utility managed the interruptible rate by use of direct load control to the customers' domestic hot water systems.(a) Service during the peak hours of each day was controlled by a timing device that interrupted service to each customer's domestic hot water heater while allowing full service to the remainder of the home. The peak hours were defined as 9 a.m. to 12 noon and 5 p.m. to $7 \mathrm{p.m}$. A flat nuisance payment was given to each customer who participated during each month of the experiment. The customers on this program faced the standard rate offered by Green Mountain Corporation.

The three-part rate structure recognized the three components of the cost of providing electricity to each customer: 1) a flat charge to cover overhead

(a) For a detailed discussion of direct load control see Section 3.5 . 
costs such as billing, 2) a per-unit charge for the energy consumed and 3) a per-unit charge for the capacity (demand) requirements placed on the system by that customer. The customer could realize savings by spreading out the household's daily consumption of electricity more evenly by not running all of their appliances at the same time.

Under the contract rate design the customer contracted with the company for a specified capacity level (e.g., maximum amount of $\mathrm{kW}$ needed per month). Within this level customers were free to use as much energy as they chose; however, if the customer's contracted level was exceeded, a significant penalty per k.W per month was charged for each $\mathrm{kW}$ that exceeded the specified amount. Interestingly, each customer, in addition to a demand meter, had an alarm that warned the customer when the contract level was being exceeded.

The inverted demand structure was similar to the contract rate; however, customers were charged an ever-increasing unit price per $\mathrm{kW}$ of demand as demand increased until a maximum of amount per $\mathrm{kW}$ per month was reached. There was no customer charge assigned.

The peak kilowatt demand rate was a variant of the standard roU rate structure. This system charged the customer a capacity charge for the demand they placed on the system during peak hours. No capacity charge was assessed for demand created during off-peak hours. The peak hours were from $9 \mathrm{a} \cdot \mathrm{m}$. to 12 noon.

As an incentive to participate, at the end of each test month customers were given a choice of what rate structure they would like to be billed under, the standard tariff or their respective experimental tariff. Due to this, the results may be somewhat biased. Consumers may have had more of an incentive to change their daily consumption patterns if they did not have a choice of rate structures.

The experiment was concluded in June 1976. During the experiment a questionnaire was sent to all the customers on the experimental tariffs to assess customers' reactions to the tariffs. The most favorable responses came from those customers on the peak period and interruptible rate structures. They found they were able to save money without experiencing any degradation in 
normal service. Many customers on the other rate structures were able to comply with the demands of their rate while others found their rate completely impossible to live under and would have, if they had been forced to pay their penalties, paid over double their regular bills.

Of the six rates, the interruptible rate was the most acceptable to Green Mountain Power and the customers. Green Mountain Power feit the TOU rate was beneficial but potential problems could arise if demand in the off-peak periods increased to a point where demand would be greater than the peak period. Further, the metering for the TOU rate was very expensive compared to the timers used on the interruptible rate.

\subsubsection{Wisconsin}

In 1975 and 1976 the Federal Energy Administration, now part of the U.S. Department of Energy, began 14 experiments that were intended to shed 1jght on the impacts of TOU rates for residential consumers. One of the more successful experiments was conducted by the Wisconsin Public Service Corporation, which serves northeastern wisconsin.

Seven hundred participants were chosen on the basis of a stratified random sample. Three different rate structures were tested having peak to off-peak price ratios of $2: 1,4: 1$ and $8: 1$. One further test included a demand charge that was in effect for a nine hour peak period. Approximately $30 \%$ of the participants were used as a control group; i.e., their peak to off-peak price ratio was $1: 1$. Customers were on the test rates for three years.

Mandatory participation in the experiment ensured that the behavior of the sampled customers would be representative of the subsets of the residential population from which they were chosen. The peak pricing periods were chosen as the hours during which the system load was highest and most likely to peak. In the summer, the system peak typically occurs between $11 \mathrm{a} . \mathrm{m}$. and noon or between $1 \mathrm{p} . \mathrm{m}$. and $2 \mathrm{p} . \mathrm{m}$. In the winter, the system peak typicaliy occurs between $5 \mathrm{p.m}$. and $7 \mathrm{p.m}$. The peak pricing periods for nonholiday weekdays were as follows: 


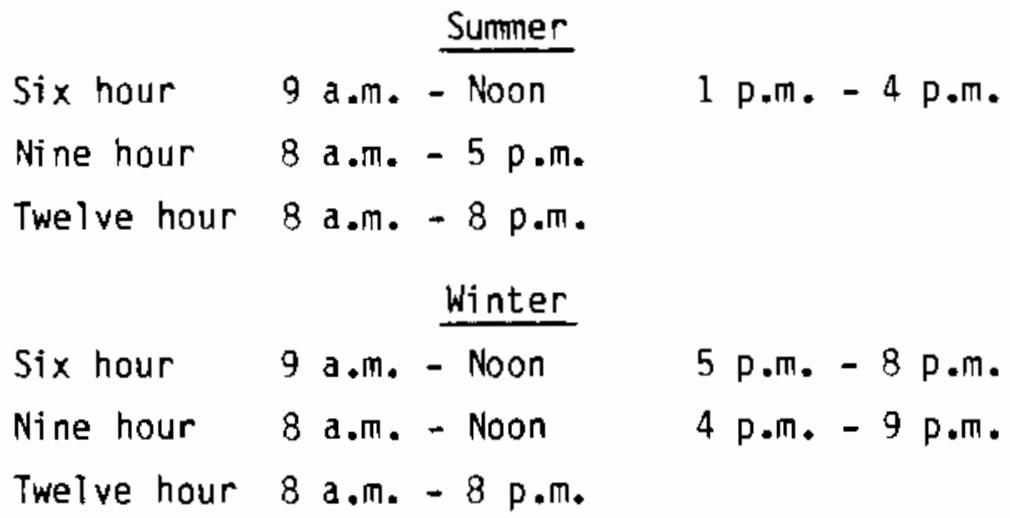

Weekends and holidays were entirely off peak. In both the summer and the winter months, the percentage reduction in peak usage was smaller for the twelve-hour peak period than for the six-or nine-hour periods. The reductions for the nine-hour period were also smaller than the six-hour period in the winter, but not in the sumer. For all three peak lengths the percentage reductions are largest for the $8: 1$ price ratio and smallest for the 2:1 price ratio. The reductions in peak-period use range from 8 to $20 \%$.

The study also found the degree of customers' response was positively related to the number of major appliances owned. Tests indicated there was a significant difference in peak reduction between customers with no major appliances and those with all five of the following major electrical appliances: air conditioner, dishwasher, water heater, range and clothes dryer. The percentage differences varied by peak length and TOU price ratio, but owners of major appliances tended to reduce their peak usage by percentages that were roughly twice as large as nonowners.

Perhaps the most important question is whether usage was curtailed at the time of the system peak. The system load for the Wisconsin Public Service Corporation peaks in the evening hours in the winter but at midday in the summer; however, the residential class peaks in the evening hours in both the summer and the winter.

Evidence showed that winter system peak savings ranged from 4 to $16 \%$ while summer system peak savings ranged from 15 to $32 \%$. The range of peak demand reduction is attributed to the different peak to off-peak price ratios. It appeared that in the winter customers were more willing to shift their midday 
usage substantially, but considerably less willing or able to shift their evening usage. The large summer reductions were attributed to high responsiveness in both the midday and evening hours.(a)

A second likely question is how total kilowatt-hour usage on TOU rates changes ( $i . e .$, whether the combination of price signals has any impact on $k$ wh usage combined over the two pricing periods). The study indicated households generally shifted their usage to the less expensive off-peak period and decreased their overall usage of electricity. This occurred in both the sumeand the winter and for the long and short peak periods. These reductions rang from $1 \%$ to $8 \%$ for the variuus TOU price ratios and peak period lengths.

It is likely that the overall reductions in peak energy consumption under the TOU rates may be understated. Consumers responded to rates that were in effect for three years; there was no indication from the consumers' perspective that these rates would prevail after the experiment was completed. Thus, it is inappropriate to assume that the households in the experiment exhibited complete long-run adjustments to Tot rates. For example, appliance purchases that would facilitate shifts in usage but would require more than a three-year payback period could not be justified. These purchases nowever, might be justified under permanent TOU rates.

\subsubsection{Oklahoma}

In 1977-1978 the Edmund Municipal Electric Company of Edmund, Oklahoma, conducted a TOU rate experiment consisting of 600 residential households. This utility is a summer peaking utility with a large portion of the system peak caused by residential air conditioning loads. This study assessed three metering options: 1) a meter that recorded, for both peak and off-peak periods, the total monthly $k$ Wh usage and the highest demand in $\mathrm{kW}$; 2) a group meter that. recorded the same information as the first but would do so for 100 or more

(a) The response in early evening hours is only based on one Tou rate as there is only one rate that has a peak period to cover the evening hours in the summer. 
customers in a subdivision at a time; (a) and 3) a seasonal rate using the existing meter. There were 200 homes per metering group.

The results of the seasonal rate analys is indicated that a 2-to-1 seasonal price ratio did not result in reductions in summer $k$ wh usage. Using an 8-to-1 peak/off-peak time-of-day price ratio, the study concluded that peak demand would be reduced by $12 \%$. When coupled with the additional costs associated with the installation of TOD meters, the benefits outweighed the metering costs for group meters for all customers except those customers whose monthly peakperiod $\mathrm{kWh}$ usage is less than $500 \mathrm{kWh}$.

\subsubsection{Potential for Peak Demand Reduction}

These experiments have provided evidence that residential Tou rates can reduce electricity consumption during peak periods. Customer response has been mainly attributed to the price differential between the peak and off-peak periods, appliance holdings, climate and customer characteristics, and the length of the peak period. The key parameter, however, is the on-peak to offpeak price ratio.

To develop estimates for the potential demand reduction in 1990 and 1995 due to the implementation of time-of-use rate structure, we made the following assumptions: 1) the peak to off-peak price ratio is 2:1; and 2) a mandatory nationwide rate structure is in effect. Further, based on the case studies, this rate structure results in a shift of peak demand of $1 \%$ in the winter and $2 \%$ in the summer. These estimates came from the low end of the case studies evaluated. Based on these assumptions, peak demand reduction in 1990 and 1995 are estimated and the results are shown in Table 3.4.

Although estimates of shifts in demand in response to TOU rates varied widely, the estimates of $1 \%$ in winter and $2 \%$ in summer were chosen because of the low peak to off-peak ratio that was assumed. The case studies examined

(a) The peak and off-peak $\mathrm{kWh}$ and $\mathrm{kW}$ information would be recorded on a group meter, and each household would be billed for its pro-rata share of the total based on the household's monthly kwh usage as recorded on its standard one-register meter. 
TABLE 3.4. Potential Peak Demand Reductions in Response

to Time-of-Use Rates

\begin{tabular}{|c|c|c|c|}
\hline \multirow{2}{*}{ Year } & \multirow{2}{*}{$\begin{array}{l}\text { Peak Demand } \\
\text { (GW) }(\mathrm{a})\end{array}$} & \multirow{2}{*}{\multicolumn{2}{|c|}{$\begin{array}{l}\text { Peak Demand } \\
\text { Reduction (GW) }\end{array}$}} \\
\hline & & & \\
\hline 1990 & 162.4 & 1.6 & 3.2 \\
\hline 1995 & 185.0 & 3.7 & 3.8 \\
\hline
\end{tabular}

(a) Based on residential energy demand from DOE 1984a.

indicated greater savings potential could be obtained with higher ratios. However, 2:1 price ratios are acceptable to customers and PUCs while larger ratios, such as $8: 1$ are not acceptable except in Europe.

\subsection{ADOPTION OF THERMAL ENERGY STORAGE AS A RESPONSE BY RESIDENTIAL USERS TO ELECTRICITY SIJPPLY CONSTRAINTS}

Thermal Energy Storage (TES) is one way to shift electrical demand from on-peak to off-peak periods. A TES system is essentialiy a space conditioning system that uses a thermal energy reservoir. This reservoir is designed to be charged during off-peak hours in a way that can provide all or most of the heating or cooling load during the utility's peak hours.

More than $50 \%$ of the energy consumed by the residential sector provides heating and cooling. Roughly $31 \%$ of this energy is currently supplied by electricity, and if current trends continue, electricity will play a more dominant role in the future (DOE 1981). Essentially all residential cooling uses electrical devices. At the end of 1981 , approximately $17 \%$ of all residentia? dwellings used electricity as a primary heating source. Because the space conditioning demand usually coincides with system peak loads, the load management potential of space conditioning by a TES system is significant. This potential is particularly high for those utilities that have high saturations of electric space conditioning appliances. 


\subsubsection{Available TES Technologies}

A number of electric space conditioning systems that use thermal energy storage have been developed that offer both the potential of meeting space conditioning needs and considerable flexibility for the utility in the delivery of electric energy. Electric heat storage systems that use ceramic brick have become cormon in Europe and in some areas of the U.S., while several other systems that use pressurized-water for heat storage, and chilled-water or ice for cool storage, have been developed and used in some experiments in the I.S. The TES systems available include:

- Ceramic Heat Storage

Electric storage heaters consist of a magnesite brick storage core heated by electric resistance wire coils at night for space heating during the following day. The level of nighttime off-peak charging is determined by a control panel that can be adjusted manually or operated automatically with an outdoor temperature sensor. Versions of this device are produced as small room units or as central units that provide heat to the entire household, and are extensively used in Europe.

- Pressurized Water Heat Storage

This design uses an insulated cylindrical pressurized steel tank in which treated water is heated by electric immersion heaters between 265 and $280^{\circ} \mathrm{F}$ at $50 \mathrm{psi}$. This system replaces a conventional furnace or boiler and may be used with various distribution methods. The standard residential unit that holds 246 gallons of pressurized water is rated at $30 \mathrm{~kW}$. This system has been experimentally tested in the U.S.

- Ice/Cool Storage

This system uses ice as a storage medium to cool warm air. The air conditioner operates during the off-peak hours to freeze the tank of water. Air conditioning is supplied to the house on demand by circulating water from the ice tank through a modified cooling-coil/airhandler in the house. The water absorbs the house heat load and 
transports it to the ice tank where the heat is absorbed by the melting ice. Most cool storage systems are designed as a unit to match standard residential air conditioning condensing units found in the home. Ice cool storage has been experimentaliy tested in the U.S.

\subsubsection{Case Studies}

Recently a few utilities have experimented with TES systems. The results obtained vary across studies; two of the more comprehensive studies were reviewed for this report.

\subsubsection{American Electric Power System}

During 1978-79, American Electric Power (AEP) undertook a study to evaluate the benefits from the use of TES heating and water heating systems. AEP's residential energy storage program monitored 71 homes in five states in their seven state service area. AEP estimated that space conditioning and water heating accounted for 60 to $75 \%$ of annual $\mathrm{kWh}$ use in an all-electric home. Coupled with a high penetration rate for new electric homes, any plan that would shift energy use to the off-peak period would be beneficial.

AEP used a heat-storage device that stored heat during an 8-hour off-peak period. It contained nine 1600-watt heating elements which were dispersed throughout the storage core consisting of 112 special refractory-type bricks. A companion direct resistance heating furnace was used to supply all nighttime, off-peak, home heating energy. The two furnaces were field coupled and controlled to function as a single TES furnace.

Over a three-year period, up to 70 of these TES heating systems were installed in customer homes across five states: Virginia, West Virginia, Ohio, Indiana and Michigan. All of the test units contained override controls on the furnace which allowed the homeowners to manually override the automatic controls and produce heating to the home during the on-peak period if needed.

Al1 of the test homes were equipped with a hot water heater designed to produce a full day's domestic hot water supply during the 8-hour off-peak period. The $12 \mathrm{D}$ gallon water heater contains two heating elements. Under 
normal conditions, the water heater was energized only during the off-peak period; however, this unit was also equipped with a manual override similar to the one contained on the furnace.

To induce participation, the homeowner purchased the TES furnace and water heater for $\$ 950$, and if at any time during the test the homeowner was not satisfied, AEP agreed to refund the purchase price and convert the home to conventional electrical space and water heating. A new rate structure was developed to motivate consumption during the off-peak period and to pass on some of the AEP's anticipated benefits. A dual-register $k$ Wh meter was used to meter peak and off-peak energy consumption for the furnace and water heater. The rate structure consisted of a fixed charge to cover the fixed costs and a peak/offpeak energy charge that had a ratio of $5: 1$. Conventional electric end-uses were metered separately and billed on the standard tariff. AEP estimated that the TES equipment saved about $\$ 0.01 / \mathrm{kWh}$ as compared to comparable homes using conventional space and water heating equipment.

AEP estimated that an average household uses about $6.5 \mathrm{~kW}$ for space and water heating during the peak period on a winter day. Since those customers on the TES program only use stored heat, the customers' electric heating demand is eliminated. As a result of the 16-hour discharge/8-hour charge cycle, the offpeak demand is increased by about twice the peak period reduction. The $\mathrm{kW}$ savings per household ranged from a minimum of $0.15 \mathrm{~kW}$ in July (a) to a maximum 6.65 in January. Extrapolating the test results for a January day at the system peak, if AEP has 50,0n0 installations, peak period demand courd be reduced by 325 MW while off-peak demand could be increased by an average of $650 \mathrm{MW}$. The increase of $650 \mathrm{MW}$ poses no burden on the system as illustrated in Figure 3.1; AEP estimated that 127,000 installations would just equate the peak and off-peak period loads.

A11 AEP test customers were surveyed at the end of the 1978-79 heating season. The survey was designed to evaluate customer attitudes towards the TES program. Overall, the survey indicated a high level of satisfaction with the operation and performance of the TES equipment. Ninety-one percent of the

(a) Summer demand reductions are due to the cycling of water heaters only. 


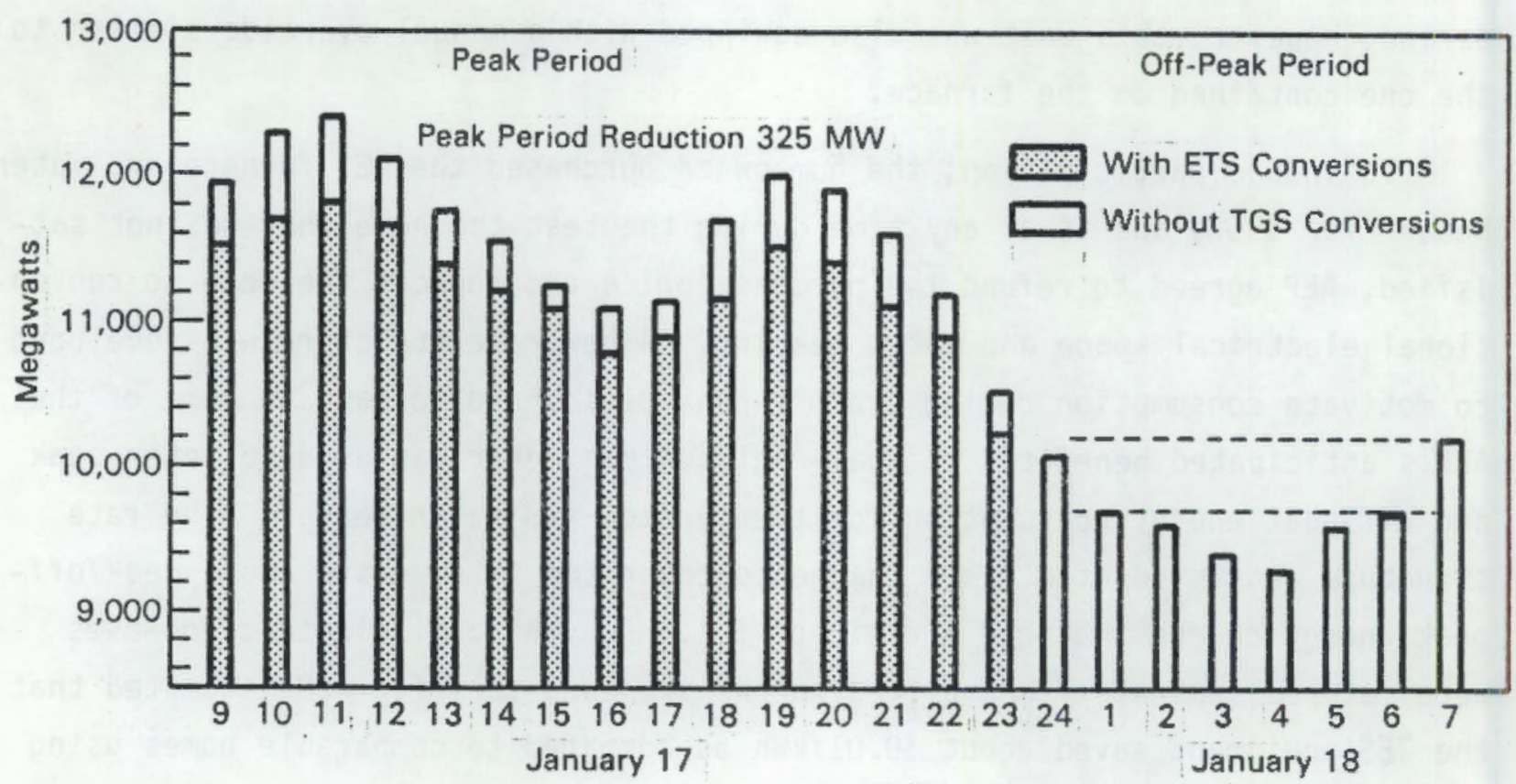

Hour

FIGURE 3.1. Effect of 50,000 ETS Conversions on the AEP System Load Shape During January 17-18, 1977

customers ranked their TES space-heating system as satisfactory and stated that it was not necessary to change their normal living habits due to the TES furnace operation. Most importantly, $94 \%$ felt the system was cost effective, and $92 \%$ said they would recommend the program to friends.

Ninety-one percent of the customers rated their supply of hot water as acceptable. Forty-five percent found it necessary to make adjustments in their normal use of hot water, while the remaining $55 \%$ found the hot water supply to be adequate.

A major impetus for the success of this program relied on a short payback period of 3 to 5 years. Five years was found to be the maximum acceptable payback period. Had an adequate tariff not been in place, this payback period could not be obtained. Secondly, if the size of the equipment was inadequate to meet the customer needs, the consumer would find it necessary to consume 
on-peak energy by activating the manual override control circuit. This is both costly and inconvenient to the consumer. If a consumer experienced frequent problems, they would most likely drop out of the program.

Contrasting results to this were found in other studies that are discussed in the following case.

\subsubsection{Electric Energy Systems (EES)}

The Division of Electric Energy Systems of the U.S. Department of Energy co-funded with participating utilities a nationwide test program to evaluate the effectiveness of TES devices. The study consisted of a number of projects covering a wide range of geographic, climatic, utility and storage system characteristics. Eight utilities participated in the project; two utilities tested both heat and cool storage systems. Tables 3.5 and 3.6 contain information about the participating utilities, the storage technologies used and the size of the sample group for both the heat and the cool storage tests.

TARLE 3.5. Summary of Heat Storage Tests

\begin{tabular}{|c|c|c|}
\hline ut ility & $\begin{array}{l}\text { Storage } \\
\text { Technology }\end{array}$ & $\begin{array}{l}\text { Sample } \\
\text { Size }\end{array}$ \\
\hline $\begin{array}{l}\text { Long Island Lighting Company (LILCO) } \\
\text { New York }\end{array}$ & $\begin{array}{l}\text { Pressurized } \\
\text { hot water }\end{array}$ & $30(a)$ \\
\hline $\begin{array}{l}\text { Public Service Electric and Gas Company (PSE\&G) } \\
\text { New Jersey }\end{array}$ & Ceramic brick(b) & $30(a)$ \\
\hline $\begin{array}{l}\text { United Power Association (UPA) } \\
\text { Minnesota }\end{array}$ & Ceramic brick (b) & $35^{(c)}$ \\
\hline $\begin{array}{l}\text { Virginia Electric and Power Company (VEPCO) } \\
\text { Virginia }\end{array}$ & $\begin{array}{l}\text { Pressurized } \\
\text { hot water }\end{array}$ & $34(d)$ \\
\hline
\end{tabular}

(a) Retrofit installations in existing homes.

(b) Domestic hot water storage also used in test.

(c) 13 were retrofit installations and the remaining 22 installations were in new homes.

(d) Installations in new homes. 
TABLE 3.6. Summary of Coo? Storage Tests

\begin{tabular}{|c|c|c|}
\hline Utility & $\begin{array}{l}\text { Storage } \\
\text { Technology }\end{array}$ & $\begin{array}{l}\text { Sample } \\
\text { Size }\end{array}$ \\
\hline $\begin{array}{l}\text { Arkansas Power and Light (AP\&L) } \\
\text { Arkansas }\end{array}$ & Ice cool storage & 29 \\
\hline $\begin{array}{l}\text { Long Island Lighting Company (LILCO) } \\
\text { New York }\end{array}$ & Ice cool storage & 50 \\
\hline $\begin{array}{l}\text { Pacific Gas and Electric company (PG\&E) } \\
\text { California }\end{array}$ & Ice cool storage & 30 \\
\hline $\begin{array}{l}\text { Virginia Electric and Power Company (VEPCO) } \\
\text { Virginia }\end{array}$ & Ice cool storage & $29(a)$ \\
\hline $\begin{array}{l}\text { Wisconsin Electric and Power Company (WEPCO } \\
\text { Wiscons in }\end{array}$ & Ice cool storage & 70 \\
\hline
\end{tabular}

(a) New home installation.

All of the heat storage tests were conducted during the 1980-81 heating season. The cool storage tests collected data during the 1980 cooling season. An additional season's data was collected in 1981 by Arkansas Power and Light and Wisconsin Electric Power Company.

In order to make each heat or cool storage test meaningful, the participating utilities chose consumers who were representative of the potential market for residential TES systems. Because of potential problems with equipment reliability and the inconvenience associated with these probiems, all of these participants were volunteers.

Each utility designed its customer incentive package based on its individual circumstances; however, all packages had two common incentives. First, all of the tests included free installation and maintenance of the TES and test equipment. Second, if customers were not satisfied with the performance of the TES equipment at the conclusion of the test, their HVAC equipment would be restored. In addition, each utility offered a range of other incentives as shown in Table 3.7. 
TABLE 3.7. Initial Customer Incentives

\begin{tabular}{|c|c|c|c|c|}
\hline Uti\}ity & $\begin{array}{l}\text { TES } \\
\text { Type } \\
\end{array}$ & TES Incentive & $\begin{array}{l}\text { Control } \\
\text { Incentive }\end{array}$ & $\begin{array}{c}\text { Equipment } \\
\text { Disposition }\end{array}$ \\
\hline AP\&L & $\mathrm{COOT}$ & $\$ 150 /$ year & $\$ 50 /$ year & $c$ or $d$ \\
\hline LILCO & $\mathrm{CoO}$ & TES F normal costs & $\$ 100$ & d or e \\
\hline PGRE & Cool & Miscell aneous $(a)$ & $\cdots$ & $d$ \\
\hline WEPCO & Cool & Residential LM rate & None & $d$ or $e$ \\
\hline WEPCO & Cool & None ${ }^{(b)}$ & Wone & $d$ or $e$ \\
\hline LILCO & Heat & TES F normal costs & $\$ 100$ & d or $e$ \\
\hline PSE\&G & Heat & Residential LM rate & $\$ 10 /$ month & $d$ or e \\
\hline UPA & Heat & $\begin{array}{l}2.5 \mathrm{C} / \mathrm{k} \text { Wh-off peak } \\
\$ 37.50 / \text { quarter }\end{array}$ & $\$ 37.50 /$ quarter & $d$ or $e$ \\
\hline VEPCO & Heat & Residential LM rate & None & $d$ or $e$ \\
\hline
\end{tabular}

(a) Free water heater blanket, low-flow shower head, $\$ 6.00 /$ month discount for May through September.

(b) Free use of air conditioning system for period of test (homes did not have $A C$ prior to test).

(c) Free title to equipment.

(d) Restoration of HVAC system.

(e) Purchase of equipment to be negotiated: $\$ 500$ - LILCO; $\$ 700$ - UPA; $\$ 100$ - VEPCO; PG\&E and WEPCO.

Results - Heat Storage. After the tests, each utility conducted surveys or face-to-face interviews to elicit consumers' attitudes towards the use of heat storage. Those customers using ceramic bricks gave mixed reviews; UPA customers tended to find these units very acceptable while the opinions of PSE\&G customers were split evenly.

Most customers felt the pressurized hot water systems were inadequate for a number of reasons including lack of sufficient heating, poor temperature regulation, poor equipment reliability, and high electric costs. Three of the utilities (LILCO, PSE\&G, and VEPCO) received complaints from their home customers about the poor heating capability and the cost of heating with the storage system. This was probably due to insufficient storage capacity and high 
standby losses. All utilities except UPA report a high number of customer overrides, indicating that the units were not operating properly or they were not sized properly for the test homes.

UPA had the most favorable customer acceptance. Thirty-two out of thirtyfive participants purchased the storage equipment upon completion of the test. Of the 35 test homes, 22 were new homes that had the systems installed at the time of construction. This fact and UPA's care in matching of the customer's heating requirements to the available unit size may have been determining factors in the test's success.

Results - Cool Storage. The cool storage program was plagued with problems. At first, test customers entered the program with high expectations; as various equipment problems cropped up, the participants were very understanding and patient. Many customers had days with little or no cooling in late afternoon and early evening. As the test progressed and various equipment problems remained, some customers asked to have their equipment removed; PG\&E and VEPCO were the only utilities who did not receive such requests. Of those customers who did want removal, the major reason was that the equipment did not provide a level of air conditioning comparable to that of their initial equipment.

The most frequent complaint was inadequate cooling in the afternoon that persisted late into the night. Numerous complaints of lack of cooling were received by all the utilities except Virginia Electric Power Company (VEPCO). For example, VEPCO received 72 calls for inadequate cooling. Of these, 30 were due to exhaustion of the available supply of ice. During the season, VEPCO accumulated 1688 house-days of experience. Customers overrode the utility control 434 times or $25 \%$ of the total house-days.

There were numerous other complaints about system failure. A large number of the customers were dissatisfied with the high electric bills during the early months of the test. The customer incentives originally planned by the utilities did not anticipate the poor efficiencies inherent in the TES equipment.

Results - EES. With the exception of a few customers, overall acceptance of both the heating and the cooling TES systems was poor. This can be mainly 
attributed to equipment failure, poor performance and no rate incentives. Had these experiments used a time-of-use rate where power could be bought at a lower rate during the of $f$-peak period, the outcome may have been more favorabie. Poor performance of the equipment may have been overcome if the units were of adequate size to meet the household's normal level of cooling and heating.

Other utilities in Europe and America have had favorable experiences with ceramic brick heating units for reasons related to properly sized equipment, the unit's location within the house, performance, purchase price and properly designed rate incentives.

\subsubsection{Potential Peak Demand Reduction}

The use of a thermal energy storage system relies primarily on two technologies; ceramic bricks for space heating and ice storage for cooling. The average cost of these systems is generally greater than a $\$ 1000$ per system. The potential $\mathrm{kW}$ savings at the time of the system peak varies, but the average is $1.5 \mathrm{~kW}$ for both space heating and cooling. The use of these devices causes an average increase in kwh consumption during the off peak period as the systems are replenishing their reservoirs. For air conditioning and room heat storage the potential increase is less than $1000 \mathrm{kwh}$ per year, while central heat storage devices have a potential greater than $5000 \mathrm{kWh}$ per year.

Table 3.8 provides an upper bound estimate for potential peak demand reduction. It is unlikely all residential consumers would find that the use of

TABLE 3.8. Potential Peak Demand Reduction for Thermal Energy Storage Equipment

\begin{tabular}{|c|c|c|c|c|c|c|}
\hline \multirow[b]{2}{*}{ Year } & \multirow{2}{*}{$\begin{array}{c}\text { Total } \\
\text { Households (a) } \\
\text { (millions) } \\
\end{array}$} & \multicolumn{2}{|c|}{$\begin{array}{l}\text { Households (millions) } \\
\text { Containing Electric }\end{array}$} & \multirow{2}{*}{ Peak } & \multicolumn{2}{|c|}{ Demand Reduction (GW) } \\
\hline & & Space heat & Air Conditioning & & Heat & Air Conditioning \\
\hline 1990 & 96.3 & 19.3 & 67.4 & 1. & & 5.1 \\
\hline 1995 & 104.1 & 23.9 & 81.2 & 1. & & 6.1 \\
\hline
\end{tabular}

(a) Source: DOE 1984a. 
TES equipment is in their best interest given the existing technologies and costs. By assuming that $5 \%$ of households that use electricity for heating and/or air conditioning installed a TES system in their home, an estimate of the potential peak demand reduction is deriver. Customer acceptance for heat storage devices has been good in Europe and to a limited extent in America, however, ice storage systems have met with little success. Poor acceptance of cool storage systems has been mainly attributed to inadequate capabilities of the existing technology.

\subsection{PURCHASE OF ENERGY EFFICIENT APPLIANCES AS A RESPONSE BY RESIDENTIAL USERS TO ELECTRICITY SUPPLY CONSTRAINTS}

In 1973, residential appliances consumed $34 \%$ of the total available electricity in the U.S., while in 1983 this figure was $35 \%$ and is expected to decrease to $32 \%$ by 1995 (Geller 1983). Although this projection is encouraging, it could be enhanced if consumers purchase more efficient appliances in the future. Efficiencies for various models of furnaces, air conditioners, refrigerators and water heaters, differ by up to $100 \%$ or more. The energy consumption of the most efficient appliances available today is dramatically lower than that of typical models produced in recent years. If the entire stock of appliances in the year 2005 consisted of the most efficient modeis now available, residential electricity consumption could decrease by as much as $37 \%$ from projections based on historical trends; Table 3.9.

Improving the efficiency of residential electrical appliances, primarily air conditioners, could significantly reduce peak electrical demand. The nation's total peak electricity demand could be reduced by $15 \%$ if all air conditioners were of the highest efficiency available in 1983. The load savings potential could be even greater on the local level. Since air conditioners are used on an average of $9 \%$ of the time, facilities built to meet this demand sit idle for a large portion of the time. A Long Island, New York utility estimated that air conditioners represented $27 \%$ of their peak summer demand; if consumers were to use more efficient air conditioners, the utility estimated 
TABLE 3.9. Comparison of Historic Trends and Best Technology Scenarios for Projecting Residential Electric Energy Consumption in 2005 Energy Consumption in Performance 2005 (Quads).

\begin{tabular}{|c|c|c|}
\hline Product & $\begin{array}{l}\text { Historic } \\
\text { Trends } \\
\end{array}$ & $\begin{array}{l}\text { Today's Best } \\
\text { Technology }\end{array}$ \\
\hline Electric Water Heat & 4.02 & 2.16 \\
\hline Central Air Conditioning & 2.33 & 1.36 \\
\hline Room Air Conditioning & 0.45 & 0.35 \\
\hline Electric Water Heat & 3.70 & 1.40 \\
\hline Refrigerators & 1.21 & 0.95 \\
\hline Freezers & 0.43 & 0.39 \\
\hline Electric Range & 0.92 & 0.61 \\
\hline Electric Dryer & 0.83 & 0.77 \\
\hline Lighting & 1.34 & 0.89 \\
\hline Other - Electric & 1.72 & 1.72 \\
\hline
\end{tabular}

Source: Geller 1983.

they could reduce their peak demand by as much as $25 \%$ over a fifteen-year period. The cost savings potential is tremendous as new facilities needed to meet peak demand would not have to be constructed.

\subsubsection{Utility Experiences}

A number of utilities have recognized the potential of energy-efficient appliances for their impact on energy savings and the avoidance of new generating facilities. Utilities can stimulate the purchase of efficient appliances through such programs as rebates, utility financing, and dealer incentives.

As of June 1983, at least 20 utilities (a) were of fering rebates to purchasers of appliances or heating and cooling equipment that meet or exceed certain levels of energy efficiency. Most of these programs are concentrated in

(a) Based on information from American Council for an Energy-Efficient Economy and the Edison Electric Institute. 
the southern states, where the peak demand occurs in the summer, due to residential air conditioning. Because energy efficient appliances reduce the internal loads (the heat rejected to the space), this not only results in direct energy savings, but also should be credited for a reduction in air conditioning energy use. Table 3.10 lists five utilities that offer rebates to homeowners and cash incentives to dealers who sell efficient appliances. This table includes the appliances for which rebates are offered and the estimated savings in peak load generating capacity.

The incentives offered differ among the utilities according to their goals. The rebates given by Texas Power and Light are given to anyone purchasing the relevant product, both builders and nomeowners. Further, dealers selling qualifying models receive a rebate for each unit sold.

Florida Power and Light has developed rebates that vary according to the degree of energy savings. This process rewards the purchaser for the amount of energy and/or capacity saved and serves as an incentive for the production and purchase of appliances more efficient than the minimum required for a rebate.

TABLE 3.10. Utility Sponsored Efficient Appliance Programs

\begin{tabular}{|c|c|c|c|c|c|c|}
\hline & $\operatorname{RAC}^{(a)}$ & $\mathrm{CAC}^{(\mathrm{a})}$ & $\mathrm{HP}(\mathrm{a})$ & $\mathrm{WH}^{(\mathrm{a})}$ & Other & $\begin{array}{c}1982 \text { Savings } \\
(M W)\end{array}$ \\
\hline Texas Power and Light & $x$ & $x$ & $x$ & & $x$ & 27 \\
\hline Florida Power and Light & & $x$ & $x$ & $x$ & $x$ & $13.7 / 6.7 / 600^{(\supset)}$ \\
\hline Guif Power Company & & $x$ & $x$ & & $x$ & 2.7 \\
\hline $\begin{array}{l}\text { Springfield, Illinois City } \\
\text { Water, Light and Power }\end{array}$ & $x$ & $x$ & & & & $15-20^{(c)}$ \\
\hline $\begin{array}{c}\text { Aust in Texas, Electric } \\
\text { Ut } 11 \text { ity Department }\end{array}$ & $x$ & $x$ & $x$ & $x$ & $x$ & 1.4 \\
\hline
\end{tabular}

(a) RAC-room air conditioning; CAC-Central air conditioner; HP-heat pump Wh-water heat.

(b) These savings are for summer, winter and expected by 1990, respectively.

(c) Projected savings by 1992. 
Gulf Power Company, located in Pensacola, Florida, offers rebates in the new construction and existing housing markets that meet a set of efficiency criteria. New construction must meet the following criteria: 1) meets specified levels of thermal integrity; 2) includes a high-efficiency air conditioner or heat pump; and 3) includes a solar, heat pump or heat recovery water heater. For existing homes only the latter two conditions must be met. For new housing, rebates range from $\$ 250$ per unit for multi-family housing to $\$ 500$ for single-family homes.

The Springfield, Illinois, utility offers $\$ 25-\$ 100$ to customers purchasing room air conditioners and central air conditioners that meet specific efficiency criteria. The Austin, Texas, utility has a rebate program for a wide range of appliances which is based on the size and efficiency of the appliance, credits for downsizing cooling equipment and dealer incentives.

\subsubsection{Consumer Acceptance}

Unfortunately, there are some caveats associated with the use of more efficient appliances. Most importantly, highly efficient residential appliances generally cost more than models of average efficiency. For example, a highly efficient air conditioner can cost more than three times the price of an air conditioner of average efficiency. (a) when comparing the total costs of the appliances over their lifetime, which includes fuel expenditures, energyefficient appliances are often very good investments. However, purchasing decisions are not solely based on the total cost of an appliance over its life time; other factors include consumer awareness, purchases by third parties (i.e., landlord, real estate agent, etc.), the nature of purchasing decisions and personal mobility.

Recent surveys have indicated that consumer response to questions on conservation only included a curtailment of consumption rather than investments in weatherization or efficient equipment. In 1982 the Good Housekeeping Institute

(a) The initial cost for more efficient appliances may not be due entirely to increased production expenses. The selling price may reflect what retail. ers and manufacturers believe the consumer is willing to pay. As competition increases in the market, the prices on some of these appliances should decrease. 
did a survey of 200 female heads of households who had purchased major appliances in the past five years. Out of twelve attributes that went into the buyers' decision process, energy savings ranked seventh. It appears that most consumers do not feel efficiency of an appliance is as important as other factors.

Further, a survey conducted in 1979 indicated that fewer than $25 \%$ of all central heating systems were purchased directly by the user. Most other appliances in newly built homes are purchased by third parties who install the equipment but do not pay the operating costs. A builder's objective is often the minimization of total cost. For rental property, the decisions of the third-party purchaser usually override the consumer's decisions not only for initial purchase, but for replacement purchases as well. If the landlord does not pay the utility bill, he will have little incentive to purchase a more expensive efficient appliance.

Consumers looking for replacement appliances are often more concerned with restoring their service as rapidly as possible. Other factors such as appearance, dimensions of the new appliance, and duratility may play a more important role in the purchasing decision.

Finally, Americans move on an average of once every five years, and owneroccupied housing units are sold every eight years on average. If a consumer plans to move or is uncertain when he might sell his house, he may be somewhat reluctant to purchase an efficient appliance if the energy saving may not be realized and if the energy efficiency is not capitalized in the resale of the appliance.

\subsubsection{Potential for Peak Demand Reduction}

Numerous kinds of energy efficient equipment and appliances are available on the market today serving all end uses from heating to lighting. The average cost of these appliances varies by the end use served. For example the use of more efficient lighting fixtures and lamps is less than $\$ 100$, while the cost of a central air source heat pump is greater than $\$ 1000$. A market penetration of $20 \%$ was assumed for all technologies. The potential savings in peak demand also varies with the technology used and end use served. Estimates range from 
$0.5 \mathrm{~kW}$ to $1.5 \mathrm{~kW}$ potential decrease per unit. The energy impact in $\mathrm{kWh}$ ranges from less than $1000 \mathrm{kWh}$ potential decrease to a greater than $5000 \mathrm{kWh}$ potential increase. Based on today's most efficient technologies for the three major end uses; space heating, air conditioning, and water heating an estimate of peak savings in 1990 and 1995 are shown in Table 3.11.

Consumers have not responded favorably to the purchase of more efficient equipment due to the high first cost of such equipment. Favorable response is generally limited to the case where some financial inducement is offered, such as a rebate. The capacity savings potential of a rebate program will differ among utilities. Some factors that affect a potential program are customer demographics, appliance saturation, and the utility load factor.

\subsection{REDUCING THE LEVEL OF ELECTRICITY CONSUMPTION BY RESIDENTIAL USERS IN RESPONSE TO ELECTRICITY SUPPLY CONSTRAINTS}

Many utilities throughout the country are either evaluating or implementing direct load control (DLC) programs in an attempt to either reduce or defer customer loads to different hours of the day. DLC refers to a system that enables the utility to interrupt power to selected appliances such as air conditioners and water heaters. Earlier systems used time switches connected to specific appliances to interrupt service, while recent DLC programs have used

\section{TABLE 3.11. Peak Load Reductions from Energy Efficient Appliances}

\begin{tabular}{|c|c|c|c|c|c|c|}
\hline \multirow[b]{2}{*}{ End Use } & \multicolumn{2}{|c|}{$\begin{array}{l}\text { Energy Consumption (a) } \\
\text { Average Efficiencies } \\
\text { Quadrillion BTU }\end{array}$} & \multicolumn{2}{|c|}{$\begin{array}{l}\text { Energy Consumption (b } \\
\text { Most Efficient } \\
\text { Technologies } \\
\text { Quadrillion BTU }\end{array}$} & \multicolumn{2}{|c|}{$\begin{array}{c}\text { Peak Savings }(\mathrm{c}) \\
(\mathrm{GW})\end{array}$} \\
\hline & 1990 & 1995 & 1990 & 1995 & 1990 & 1995 \\
\hline Space heat & 0.36 & 0.46 & 0.19 & 0.25 & 1.8 & 2.3 \\
\hline Water heat & 0.37 & 0.42 & 0.22 & 0.25 & 1.7 & 1.9 \\
\hline Air conditioning & 0.43 & 0.49 & 0.16 & 0.19 & 2.9 & 3.3 \\
\hline
\end{tabular}

(a) DOE 1984 .

(b) Geller 1983.

(c) Based on a load factor of 0.62 and a conversion of $1 \mathrm{kWh}=3412$ BTUs. 
communication systems that allow utilities to remotely activate or deactivate load control devices located throughout their service area. There are three benefits associated with the use of a DLC program: 1) the utility may improve its load factor; 2) additional facilities needed to provide peak power may be deferred; and 3) customers ' loads can be deferred with few, if any, adverse impacts on Tifestyles.

\subsubsection{Appliances Controlled by DLC}

Certain appliances in the residential sector have been targeted for use in DLC programs. These include electric water heaters, air conditioners and space-heating equipment. Although other appliances' loads could be controlled, these three end-uses contribute to the major portion of the residential peak load demand.

The electric water heater is the appliance that has received the most attention in terms of its load-deferral potential. This is due to two major reasons. First, due to its inherent themal storage capabilities, a water heater represents one of the few residential loads that is truly deferrable in that it can generally be controlled to the point where electricity demand is reduced without adversely affecting the lifestyle of the customer. Secondly, the electric water heater represents a relatively high-load appliance that sees year-round use, offering potential for demand reduction in both winter and summer peaking utilities.

The demand reduction potential realized from electrical water heater control will be directly related to the time of day that water heaters are used. Water heaters generally have two peaks: mid-morning between 7:00 a.m. and 10:00 a.m. and early evening, 5:00 p.m. to 8:0D p.m., which coincide with the peak periods for electricity usage, Figure 3.2 .

The central residential air conditioner is another candidate for load control. One major reason is that air conditioning presents a significant contribution to peak demand during the summer. For example, the Public Service Company of Oklahoma's peak period is during the early evening on a summer day (IEEE 1985). Studies show that residential air conditioners comprises $39.33 \%$ 

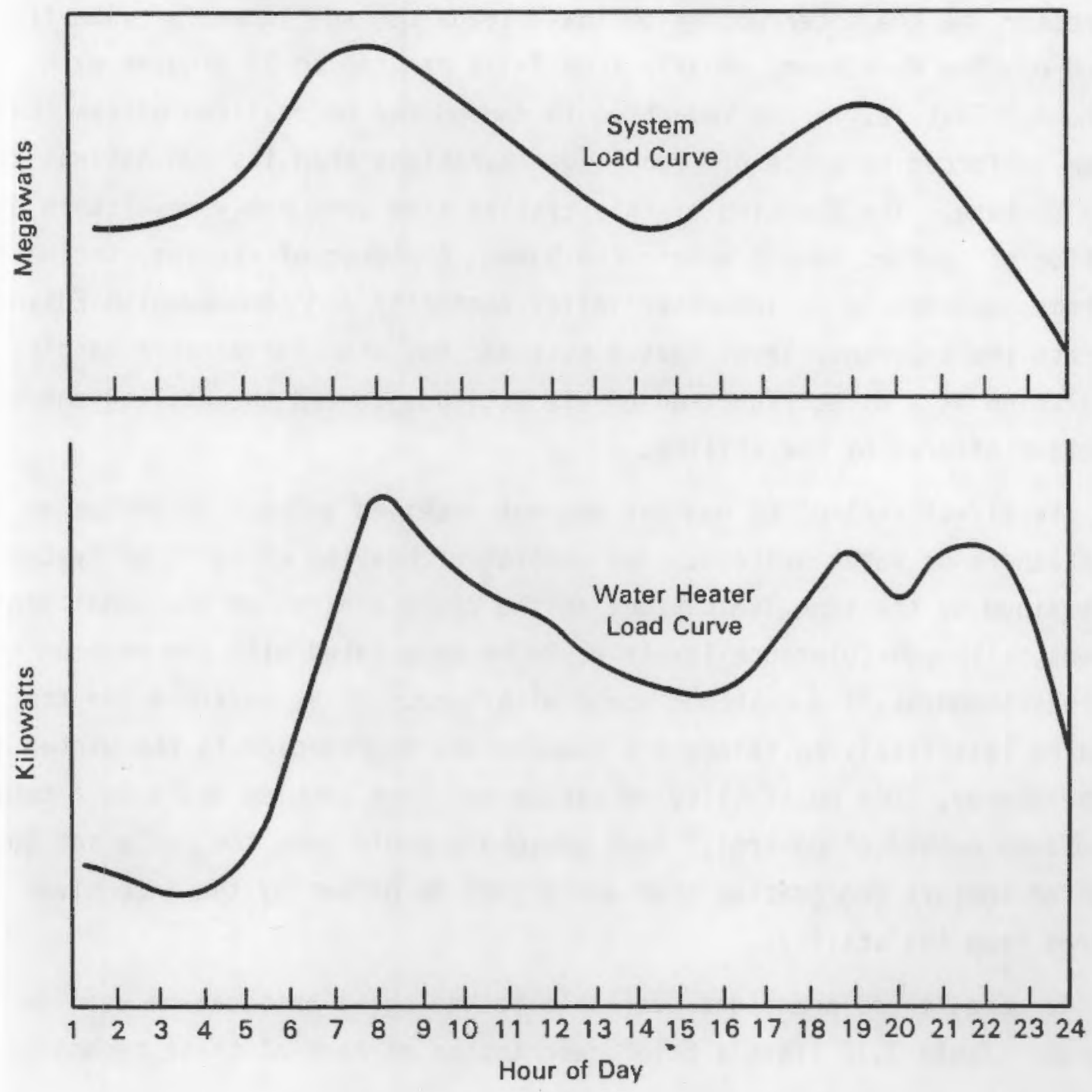

FIGURE 3.2. Comparison System Load Curve to the Load Created by a Water Heater

of the total load placed on the utility, including all other classes of consumers (i.e., municipal, commercial and industrial). Although it is clear that air conditioners do require a significant amount of power, the benefits derived from the direct control of air conditioners are less tangible.

An air conditioner is not really a deferrable load in the sense that it cannot be cycled off for any length of time beyond its own natural off-cycle time without some resultant degradation of comfort levels within the home. The standard method of remote air conditioning cycling involves the shut off of the 
compressor via the interruption of low-voltage control lines for some fixed period of time each hour, usually from 7-1/2 minutes to 18 minutes each $1 / 2$ hour. That is, no net reduction in demand can be realized unless the system is forced to cycle off for longer durations than its own natural cycling would dictate. The limiting of this cycling time presumably results in a degradation of comfort levels within the home. A number of studies, including programs implemented by Tennessee Valley Authority and Commonwealth Edison, indicate the tolerance level that a customer may show for comfort condition degradation is a direct function of his attitude toward the utility and/or the incentive offered by the utility.

The direct control of heating has not received as much attention as air conditioners or water heaters. The control of heating circuits or systems is constrained by the same limitations as the cycle control of air conditioning systems, although tolerance levels would be associated with the minimum internal temperature a customer would withstand. It is possible the consumer would be less likely to tolerate a temperature degradation in the winter than in the summer. One possibility to circumvent this problem would be a temperature-based method of control. Each household could have the cycle set to a level of comfort degradation that would just be offset by the incentives offered from the utility.

To date, there are eight available technologies that can be used in a DLC program. Table 3.12 lists a brief description of each of these technologies.

\subsubsection{Case Studies}

Three case studies and a review of DLC programs sponsored by the Electric Power Research Institute have been chosen for review. The three individual case studies include an extensive program carried out by Tennessee Valley Authority, Cobb Electric Membership Corporation and Commonwealth Edison. These studies were chosen as the results are representative of results found by other utilities throughout the country. 
TABLE 3.12. Direct Load Control Technologies and Characteristics

- Radio is the most widely used system in the United States. The technology is well-advanced, so cost, performance and reliability are predictable. The cost per consumer controlled (per point cost is about $\$ 250$, including installation) is lower than for the other systems. The flexibility of radio is generally limited in terms of receiver address capability. Signal propagation is affected by terrain or man-made objects.

- Ripple has been widely used in other countries. It uses low frequency signals transmitted over power lines on the utility system. Ripple offers increased flexibility, increased signal reliability and similar equipment reliability as compared to radio. However, the cost is higher.

- Unidirectional PLC (power line carrier) is similar to ripple but uses a higher frequency so signal attenuation is greater. PLC requires less signal power than ripple to achieve an acceptable signal-tonoise ratio.

- Bi-directional PLC uses a transponder at the control point which can respond to a command from the central control. Responses include verification of location, receipt and performance of command, meter reading and monitoring of distribution system functions and instrumentation. PLC systems normally combine unidirectional and bi-directional so that the higher cost bi-directional is used only where required.

- Combination Radio and PLC uses radio to transmit to receivers at distribution transformers. Each receiver then sends the signals by PLC to individual control points. This system offers increased addressing capability and slightly better signal performance than total radio at a higher cost.

- Priority Relay interlocks two appliances so that both cannot be on at the same time. This can limit the individual consumer peak, but the control may or may not be at the time of the utility's peak load.

- Load Management Thermostat controls the air conditioner or heating system based on outdoor temperature, indoor temperature, time of day or a signal from the utility. Thus, it may be site-specific, similar to the priority relay, or directly related to the utility peak.

- Programmable Demand Limiters are small microprocessors which control multiple loads based on some preprogrammed scenario. Initiation of control can be from measured demand, time of day or a remote signal from the utility. 
3.5.2.1 Tennessee Valley Authority (a)

From July 1979 to March 1981 the Tennessee Valley Authority (TVA) conducted a test project invoiving 457 single-family homes to quantify benefits to be gained from managing residential water heating and space conditioning (both heating and cooling). These homes were selected from four distributor areas representative of the broad range of climatic and geographic variations, and time-zone differences in the TVA service area. This study also included an assessment of consumer acceptance of direct load control.

To evaluate the benefits from DLC, load management of participant appliances was implemented on alternative weeks, and baseline information was collected during intervening weeks. Thus, the control group was made up of the participants in the study.

The load control system consisted of an FM radio central controller, four base station transmitters (one located in each participating distributorship), and radio-controlled switches installed on residential appliances. These appliances were monitored through an FM radio signal from a base station receiver to the radio receivers on the residential appliances.

Participating consumers received incentive payments according to the following schedule.

- Consumers with only standard water heaters managed received $\$ 50$.

- Consumers with standard water heaters and central heating or cooling systems managed received $\$ 90$.

- Consumers with TVA-supplied 120-gallon storage water heaters and central heating or cooling systems managed received the water heater as their incentive for participating.

Water Heater Program. The water heater experiment consisted of 457 households broken into two groups. The first group was comprised of 358 households

(a) TVA is a wholesaler of power to 160 power distributors located in seven states. These distributors in turn sell power to all residential and most commercial and industrial end-use customers. 
equipped with standard water heaters that were installed before the experiment. Each of the remaining 99 households received a super-insulated, 120-galIon water heater to replace their existing water heater. The average demand reduction per water heater was the difference between the managed demand and the demand that would have been present had the water heater not been managed.

During the winter, the TVA system peak demand usually occurs around 8 a.m. or $9 \mathrm{a} . \mathrm{m}$. The results of the data analysis revealed that the average potential demand reduction is $1.4 \mathrm{~kW}$ per standard water heater during the winter months.

The TVA summer system peak demand usually takes place between 4 p.m. and $6 \mathrm{p} . \mathrm{m}$. in the month of July. The summer managed water heater data indicated a potential reduction of $0.39 \mathrm{~kW}$ per water heater.

Figures 3.3. and 3.4 show the average managed and unmanaged electric water heater load curve for the seasonal peak months. Both managed curves for the summer and winter show large needle peaks after the water heaters are turned on. This result occurs because most of the energy denied during the management period is made up relatively quickly when the water heaters are allowed to draw

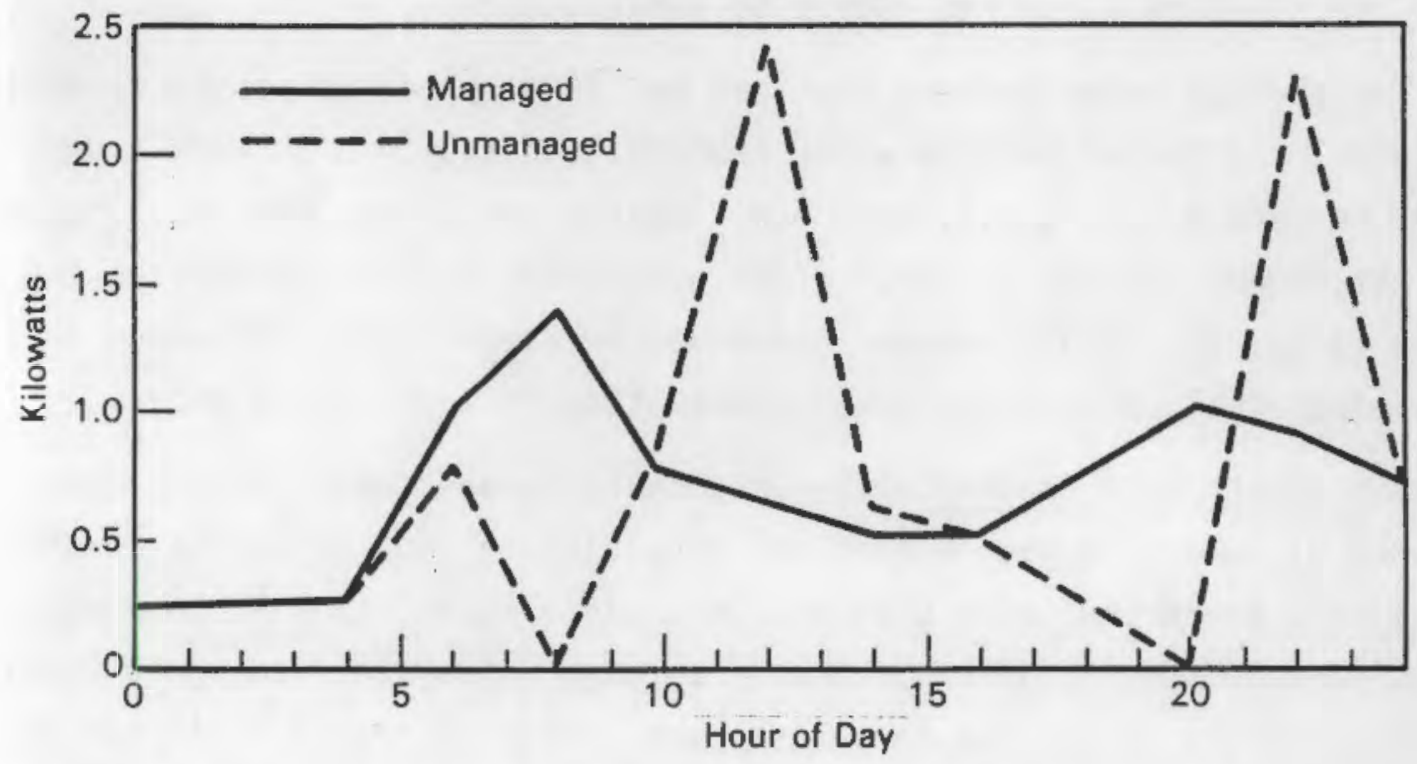

FIGURE 3.3. Standard Water Heaters Valley-Wide Average, February 1981 


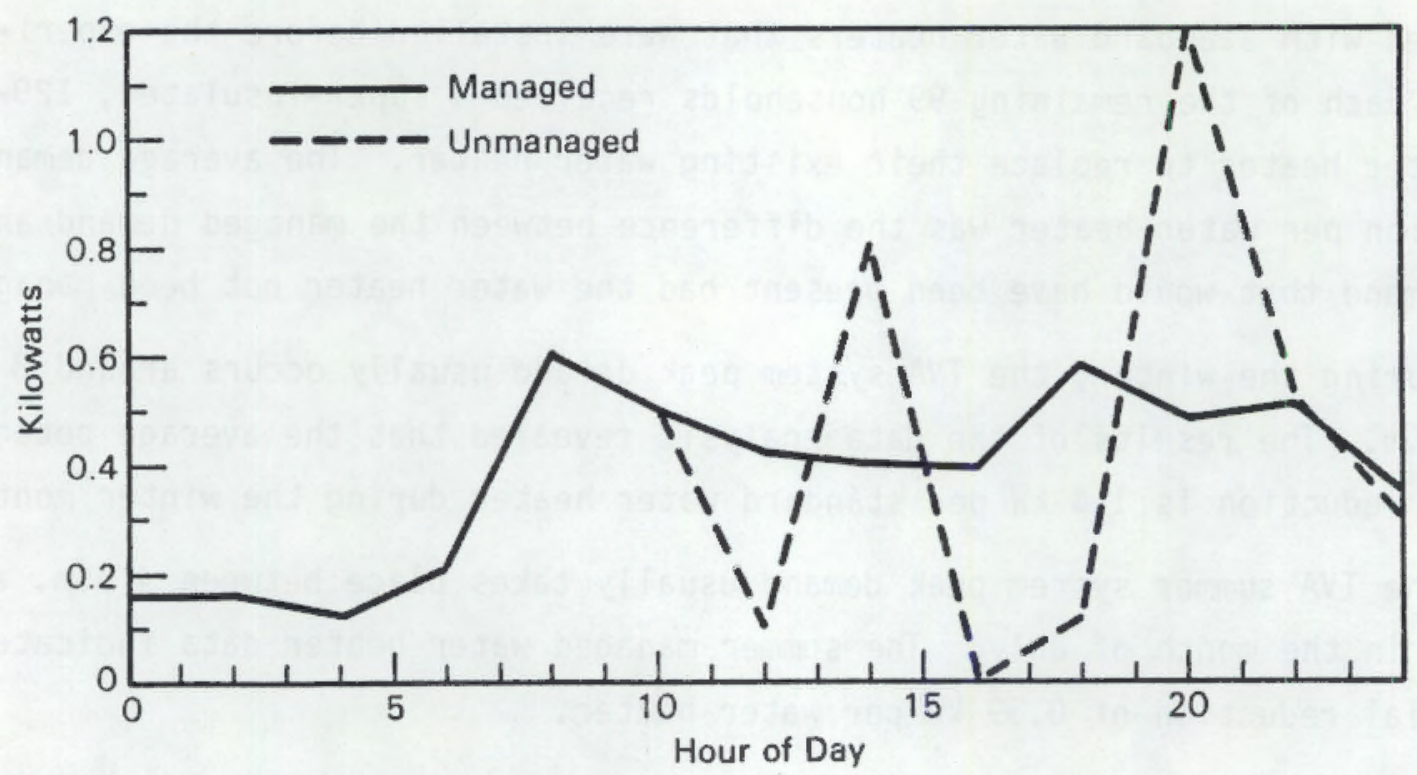

FIGURE 3.4. Standard Water Heaters Valley-Wide Average, July 1980

electrical energy after being off, which is commonly referred to as the payback period. This problem could be minimized by subdividing a large number of controlled water heaters into separate management groups and using control schedules that feature staggered return to service strategies.

The storage water heaters provided by TVA were on two separate seasonal schedules. In the winter the water heaters were cycled off twice a day: $8 \mathrm{a} . \mathrm{m}$. to $12 \mathrm{a} \cdot \mathrm{m}$. and $5 \mathrm{p} . \mathrm{m}$. to $9 \mathrm{p} . \mathrm{m}$. During the summer the water heaters were off from $2 \mathrm{p} . \mathrm{m}$. to $10 \mathrm{p} . \mathrm{m}$. After accounting for differences in the scheduling times, the results showed there was no significant difference in average daily electrical consumption between the standard and storage water.

Air Conditioner Program. The load control experiment for air conditioners included 91 homes; 30 had central air conditioning $(A C)$ while the remaining 61 had heat pumps that were used in the cooling mode. Each AC compressor was cycled from 12 noon to 10 p.m., Monday through Friday, excluding holidays. When cycling did occur, the compressor was turned off for 7.5 minutes out of every 30 minutes. Indoor fans were allowed to run continuously to permit air circulation within the house. 
The results showed cycling AC units during the TVA system peak period could be effective in reducing system peak demand. An average estimate of $1 \mathrm{~kW}$ demand reduction per $A C$ unit was found. These estimates ranged from $0.5 \mathrm{~kW}$ for $A C$ with a connected load of $2.0 \mathrm{~kW}$, to $1.93 \mathrm{~kW}$ reduction for $\mathrm{AC}$ units with a connected load of $7.7 \mathrm{~kW}$.

Space Heating Program. The TVA system winter demand profile is not only a function of residential water heaters but also residential central forced-air electric resistance space heating. Because this type of heating can require a large kW demand, potential system benefits were analyzed. Several central forced-air electric furnaces were included as part of the water-heating/spaceconditioning control test. These forced-air heating units were cycled and monitored to gather hourly furnace demand data and to determine if significant hourly diversified demand reduction can be achieved through cycling.

of the 47 homes that were used, 14 had electric furnaces that were cycled while the other 33 homes were used as a control group. All 47 homes used central forced-air electric resistance heating as the primary heating source. Management occurred on alternate weeks for those 14 homes originally equipped with receiver switches. When cycled, an electric furnace was shut off for 7.5 out of every 30 minutes.

The analysis of the forced-air electric furnace data indicated that a $25 \%$ off time during peak demand periods did not achieve significant demand reductions. Extrapolation of the data implied that at least $50 \%$ of $\mathrm{f}$ time would be necessary to achieve significant demand reductions through cycling. However, customers may not accept a large percentage of off time, especially on the coldest days in the winter.

Summary TVA Program. The study indicated that DLC of standard and storage water heaters can achieve a $1.36 \mathrm{~kW}$ peak demand reduction per unit during winter months and a $0.39 \mathrm{~kW}$ demand reduction per unit during the summer months. Management of residential central AC can produce a $1.0 \mathrm{~kW}$ peak demand reduction per unit on very hot summer days when the maximum daily temperature reaches at least $100^{\circ} \mathrm{F}$. A $0.65 \mathrm{~kW}$ peak demand reduction per $\mathrm{AC}$ unit could be achieved on a day with a maximum temperature of $96^{\circ} \mathrm{F}$. Analysis of the space heating data yielded less favorable results. 
Less than $2 \%$ of the test participants stated that they would not take part in a load management program on a permanent basis.

As a result of this program, TVA, in March 1981, initiated a larger follow-up program to introduce the DLC to the TVA service area.

TVA's Follow-Up Program. Currently, TVA is offering a cycling program designed to shift demand from peak to off-peak hours. As of July 1982 there were 26,490 program enrollees on the air-condition cycle program and 12,800 participants in the water heating program. Cycling is accomplished through an FM radio control system. Upon receiving a signal, the receivers cycle AC compressors for 7.5 minutes out of each half-hour during the control period and cycle water heaters for up to 4 hours.

The cycled appliances are grouped into blocks which are cycled as one unit. The staggered cycling of blocks increases the period of reduced demand and decreases the probability of creating a new peak from demand surges as the appliances in each block are returned to service.

The cost of furnishing, installing, inspecting and maintaining the receiver switches is paid by TVA with no charge to the program participants. Households in the $A C$ cycling program receive a $\$ 5-p e r-m o n t h$ bill credit, June through September, and residents in the water heater program receive a \$2-permonth credit year round.

By 1986 TVA expects these programs will save up to 317 megawatts in peak demand: $140 \mathrm{MW}$ reduction in air conditioning and 177 MW from water heater cycling.

\subsubsection{Cobb Electric Membership Corporation Study}

Since the summer of 1976, Cobb Electric Membership Corporation (Cobb EMC), located in Marietta, Georgia, has been involved in the direct load control of water heaters and air conditioners. This program was implemented to reduce peak load demand during the summertime. Originally, a radio system with a remote control switch was installed on 5000 air conditioners. Because this program had met with great success, by the summer of 1983 there were an average of 21,200 air conditioner switches and 1700 water heater switches installed. 
Initially, 5000 out of 31,000 members were chosen to participate in the program. It was believed that those members with the highest kWh usage during the previous summer would be the most willing to participate; however, most of these consumers had large incomes with electricity representing only a smal? portion of their monthly expenditures. These consumers felt comfort provided by the air conditioner was a more important consideration than cost savings. To enroll 6000 members in the program, Cobb EMC had to use a number of consumers with lower monthly consumption levels. In 1978 an incentive was provided; those with controlled AC received $\$ 1.00$ per connected $\mathrm{kW}$ load for each summer month and $\$ 0.30$ per connected $\mathrm{kW}$ load for water heating during the summer months.

During the first summer, the approach in operating the system required 7 of 27 minutes curtailment on a rotating basis to shed the maximum power flow rate. This equates to $26 \%$ curtailment or 2.3 interruptions per hour. With $26 \%$ curtailment, the total interrupted time summed to 51.49 hours over 20 days for the entire summer. An average of $1.56 \mathrm{~kW}$ was saved per switch. There were no apparent complaints from consumers.

In 1978 Cobb EMC added 600 water heater switches. The average savings during the peak period ranged from 0.9 to $1.0 \mathrm{~kW}$.

Consumer response overali was favorable. Cobb EMC sent out a survey to 3660 members; of those returned, $96.5 \%$ felt the program was worthwhile and generally had positive feelings. The remaining $3.5 \%$ had negative comments about the program: of these, $81 \%$ had objections to the rates, and $19 \%$ expressed discomfort or other problems related to the switch. The consumer was not billed for the installation of the meters. Any costs they incurred would be intangible costs associated with their level of discomfort.

\subsubsection{Commonwealth Edison Company Study}

Commonwealth Edison Company, located in Chicago, Illinois, is a summerpeaking utility with approximately 2.8 million residential customers. While this class accounts for one-third of the company's annual megawatt-hour sales, it comprises about $40 \%$ of the summer peak load with air conditioning loads being the major contributor (Juracek 1982). 
A suburban subdivision had been selected for the test site. of the 456 households, 97\% contained air conditioning units. A letter was sent explaining the program to each customer in the selected area. The final experiment included 242 households. The test was conducted from the spring of 1980 through the summer of 1982. Each participating household had a control wire from the remote teminal unit to a low-voltage thermostat circuit at the outside of the compressor/condenser unit.

To induce participation, the customers were offered an $18 \%$ credit on each of their four summer monthly electric bills and a free inspection of the customer's air conditioning system. In return, the company allowed interruption in service to the central air conditioning compressor for periods up to 15 minutes in any half-hour. The interruptions were restricted to the hours of $9 \mathrm{a} \cdot \mathrm{m}$. to $10 \mathrm{p.m}$. excluding weekends and holidays. Of those households that did not want to participate, some either were moving or had no central air conditioning while the others said that the credit was not large enough or that they did not like "Big Brother" watching.

During an average sumer in Commonwealth Edison's service territory there are 119 hours warmer than $90^{\circ} \mathrm{F}$ and 338 hours warmer than $85^{\circ} \mathrm{F}$. To maximize the number of hours in which significant load reductions could be seen, a cycle of 12 minutes off and 18 minutes on from the hours of 9 a.m. to $10 \mathrm{p} . \mathrm{m}$., excluding weekends and holidays, was chosen. The average reduction at the time of the system peak was $1.058 \mathrm{~kW}$ per air conditioning unit.

A marketing research firm was commissioned to conduct telephone surveys of a11 240 participants during the evening of particularly hot days. At the end of the summer a mail survey was sent to all the participants. Summarizing the surveys, 46-47\% felt comfortable, 9-11\% felt uncomfortable, 25-30\% had no adult present or no air conditioning on in the afternoon and $14-18 \%$ could not be reached. The mail survey was designed to increase the participants' overall perception of their comfort over the cooling season, and the problems of continued participation were the cycling to become permanent, rather than experimental. Based on the responses, $95 \%$ were satisfied with their level of comfort in their homes; $92 \%$ showed willingness to sign up on a permanent basis, 
although many stated that would depend on the discount rate offered. Seven customers indicated that a $15 \%$ discount was not worth any discomfort they may have experienced.

\subsubsection{EPRI Survey}

The Electric Power Research Institute (EPRI) has sponsored surveys of utility activities related to direct load control (EPRI 1984a). The 1981 survey identified a total of 210 load control projects being conducted by 170 different utilities dispersed throughout the continental United States. of these projects, 104 represent nearly system-wide comitments on the part of the utility to implement load control. These programs range in scope from more than 100,000 points of load control to less than 500 points.

The 210 load control projects involve the control of more than 890,000 loads, which includes 552,000 electric water heaters, 310,000 air conditioners and 6,000 space heating systems (Table 3.13). The majority of these projects used VHF FM radio as a control technology: 103 projects with 671,000 points of control.

Participation. Forty percent of the load control programs identified carried no direct monetary incentive. The programs that did provide some monetary

TA8LE 3.13. Peak Savings from Direct load Control Programs for Surveyed ltilities

\begin{tabular}{|c|c|c|c|c|}
\hline \multirow[b]{2}{*}{$\begin{array}{c}\text { Geographic } \\
\text { Locat ion }\end{array}$} & \multirow[b]{2}{*}{$\begin{array}{l}\text { Number of } \\
\text { Utilities }\end{array}$} & \multicolumn{3}{|c|}{ Points of Control } \\
\hline & & $\begin{array}{l}\text { Water } \\
\text { Heaters } \\
\end{array}$ & $\begin{array}{c}\text { Air } \\
\text { Conditioning }\end{array}$ & $\begin{array}{l}\text { Space } \\
\text { Heat }\end{array}$ \\
\hline Northeast & 18 & 17,000 & 1,000 & 1,000 \\
\hline East Central & 13 & 252,000 & 3,000 & 0 \\
\hline Southeast & 71 & 135,000 & 134,000 & 0 \\
\hline West Central & 52 & 126,000 & 6,000 & 5,000 \\
\hline South Central & 26 & 3,000 & 81,000 & 0 \\
\hline Northeast & 2 & 3,000 & -- & - \\
\hline West & 28 & 16,000 & 85,000 & $=$ \\
\hline & 210 & 552,000 & 310,000 & 6,000 \\
\hline
\end{tabular}


incentive did so through the form of monthly credits on the customer's electric bill. These credits generally range from two to ten dollars per month for each appliance controlled and are typically administered for three to five months during the utility's seasonal peak period. Incentive payments are typically higher for air conditioners than water heaters as there is a higher level of inconvenience associated with the cycling of air conditioners. Control of conventional heating systems falls under a monthly credit system similar to that offered by most AC programs.

The remaining rate/incentive systems are somewhat novel in their approach and will be briefly discussed. Some utilities have offered special rates to controlled customers, which applies a percentage reduction to monthly bills. Nine utilities offered reductions that ranged from $9 \%$ to $15 \%$.

Another option involves the installation of submeters on controlled appliances and allowing a special reduced rate on the submetered consumption. Among the utilities offering this option is Detroit Edison, which gives approximately a $50 \%$ reduction on the controlled appliances cost.

The municipal utility of Lawrenceville, Georgia, assesses all nonparticipants an extra $\$ 10$ per month as a penalty for not allowing control. Still another utility offers a profit-sharing plan whereby $50 \%$ of each year's estimated savings in peak capacity costs are divided and distributed among controlied participants.

Peak savings resulting from these DLC programs for some of the utilities that were surveyed are listed in Table 3.14. These estimates vary by geographic location and will be dependent upon the utility's characteristics. The estimates range from 0.4 to $1.5 \mathrm{~kW}$ reduction for water heaters and 0.6 to $1.6 \mathrm{~kW}$ for air conditioners.

Assessment of Consumer Acceptance. An important parameter in determining the success of a direct load control (DLC) progran is the consumer acceptance or willingness to stay on or join a DLC program. The following information is based upon a number of surveys conducted by individual utilities who have or currently are operating a DLC program. 
TABLE 3.14. Peak Savings from DLC Programs Selected from the 1981 EPRI Survey Coincident Demand Reduction per Water Heater

\begin{tabular}{|c|c|}
\hline Utility & $\begin{array}{c}\text { Demand } \\
\text { Reduction }(\mathrm{kW})\end{array}$ \\
\hline Buckeye Power & 0.9 \\
\hline Carolina Power and Light Company & 1.2 \\
\hline Central Wisconsin Electric Cooperative & 1.0 \\
\hline Oetroit Edison Company & 1.0 \\
\hline Florida Power Corporation & 0.9 \\
\hline Grant Electric Cooperative & 1.0 \\
\hline New Hampshire Electric Cooperative & 1.5 \\
\hline Shenandoah Valley Electric Cooperative & 1.4 \\
\hline Sumter Electric Membership Corporation & 0.3 \\
\hline Virginia Electric and Power Company & 0.4 \\
\hline Average & 0.96 \\
\hline \multicolumn{2}{|c|}{ Demand Reduction per Air Conditioner } \\
\hline Utility & $\begin{array}{c}\text { Demand } \\
\text { Reduction }(\mathrm{kW})\end{array}$ \\
\hline Arkansas Power and Light Company & 1.00 \\
\hline College Park Electric System & 1.00 \\
\hline Conway Corporation & 1.60 \\
\hline Florida Power Corporation & 0.60 \\
\hline Lawrenceville Electric Department & 1.25 \\
\hline Sacramento Municipal Utility District & 1.00 \\
\hline Sumter Electric Membership Corporation & 0.90 \\
\hline Average & 1.05 \\
\hline
\end{tabular}

Most surveys found public attitudes towards DLC are not well defined or particularly stable. Because most residential customers have little or no experience with load control, they have 1 imited information, and the opinions expressed in surveys could easily change or be influenced by a variety of factors, including the manner in which the questions were asked. Overall 
customers with no experience in OLC have generally favorable attitudes towards DLC while those consumers who had been on a program showed even more favorable attitudes.

As a group, those people willing to sign up had similar attitudes, such as a greater awareness or knowledge of the program, a belief that OLC will conserve energy or reduce demand, that the program will save them money, and less concern about comfort or utility control. Those people who were not willing to participate either had ill feelings toward their utility, did not want someone else to control their appliances or felt the compensation offered by the utility was not sufficient to justify any discomfort they might experience.

Of the peopie that were on an AC program, $68 \%$ to $97 \%$ felt no discomfort or inconvenience while $78 \%$ to $97 \%$ of the people on water heater programs gave the same response. Over $90 \%$ of the consumers who participated in a test program wuld stay with a program if it were permanent, and the majority of nonparticipants stated they would sign up for a DLC program if it was offered. Most of the people not willing to stay with a program had numerous equipment failures. Interestingly, a majority of the respondents stated the level of monetary compensation was not a determining factor in whether they would participate or not.

\subsubsection{Conciusions}

In conclusion, the majority of surveys had five points in common:

1. There is no evidence of strong negative attitudes towards DLC programs in the residential sector.

2. Customers are more likely to participate if they see the program as effective in solving energy problems, have more knowledge, and have positive attitudes towards the utility.

3. Customer concern about utility control plays a very small role in participation. Most customers are willing to cooperate with the utility. 
4. Equipment failure, not attitudes, is the main reason for dropping out.

5. The participants reported that the magnitude of incentives had littie to do with their participation in the programs.

\subsubsection{Potential Peak Demand Reduction}

Direct load control (DLC) of specific end uses such as space conditioning and water heating are being used extensively by a number of utilities in the U.S. Current technologies allow the utility to control the power flowing to certain end uses thereby enabling them to reduce demand at the peak period. The cost of a OLC device ranges from $\$ 100$ for a temperature activated switch to $\$ 1000$ for a programmable control unit.

Potential peak savings range from 0.3 to $1.5 \mathrm{~kW}$ depending on the end use that is controlled and season. The energy impact in off peak hours for air conditioners is less than $1000 \mathrm{kWh}$ potential decrease, while information pertaining to other end uses is not readily available. Control of water heaters has met with more favorable acceptance by consumers than space conditioning end uses.

Assuming that $10 \%$ of all households that use electricity for water heating, space heating, and/or air conditioning will use direct load control devices an estimate of peak savings is estimated and shown in Table 3.15 for 1990 and 1995.

TABLE 3.15. Potentia1 Peak Demand Reduction from Direct Load Contro1

\begin{tabular}{|c|c|c|c|c|c|c|c|}
\hline \multirow[b]{2}{*}{ Year } & \multirow{2}{*}{$\begin{array}{c}\text { Homes } \\
\text { (millions) } \\
\end{array}$} & \multirow{2}{*}{$\begin{array}{l}\text { End } \\
\text { Million } \\
\text { HT }\end{array}$} & \multicolumn{2}{|c|}{$\begin{array}{l}\text { Use } \\
\text { Households }\end{array}$} & \multicolumn{3}{|c|}{$\begin{array}{c}\text { Potential } \\
\text { Reduction (GW) (b) }\end{array}$} \\
\hline & & & $A C$ & Wh & HT & $A C$ & WH \\
\hline 1990 & 96.3 & 21.7 & 51.5 & 55.3 & 1.3 & 3.1 & 1.7 \\
\hline 1995 & 104.1 & $2 B .1$ & 59.8 & 63.7 & 1.7 & 3.6 & 1.9 \\
\hline
\end{tabular}

(a) Penetration rates derived from ORNL residential energy use simulation runs.

(b) Assumes a reduction of $0.6 \mathrm{~kW}$ for heating and air conditioning and a $0.3 \mathrm{~kW}$ reduction for water heating. To be conservative, we used the lowest estimates found. 


\subsection{FUEL SWITCHING AS A RESPONSE TO ELECTRICITY SUPPLY CONSTRAINTS}

One possibie response by residential consumers to electricity supply constraints, would be the adoption of fuel switching methods that would reduce consumer reliance on electricity.

The demand for electrical services is influenced by a number of parameters including income, tastes, the price of electricity and of other fuels, and the availability of electricity. The demand for electrical appliances would most likely decrease if consumers perceive a degradation in the normal supply of electricity. The extent to which demand will shift in response to decreases in availability is not clear. Consumers may not be willing to switch fuels unless it is financially advantageous for them to do so. Price trends, in 1984 dollars, indicate fossil fuel prices are expected to rise $31 \%$ by 1995 , while electricity prices should decrease hy $1.27 \%$ on average (DOE 1984a). As such, residential electricity usage as a percentage of total energy consumption is expected to rise slowly but steadily through the end of the century. (a)

The type of fuel switching that is technically feasible in a supply constraint situation is a function of the season of the year and the time of day that the disruptions occur, and of the electricity consuming activities that are impacted. For peak supply constraints occurring during the summer months, the main residential functions impacted wili include air conditioning, refrigeration, water heating, and other miscelianeous functions such as television operation. For peak supply constraints occurring during winter periods, consumption activities impacted would be similar except that space heating rather than air conditioning would be likely to be disrupted. Table 3.16 outlines the major energy consuming uses that would be impacted in the event of electricity supply constraints along with technically feasible methods of fuel switching.

Whether customers will switch to an alternative fuel in face of electricity supply constraints will depend on several factors. In many cases, no suitable substitute for electricity is available, such as for refrigeration. In

(a) J. Reilly et al. 1996. Residential Fuel Shares: 1960 to 1995. PNL Oraft Report. 
TABLE 3.16. Potential Methods of Fuel Switching

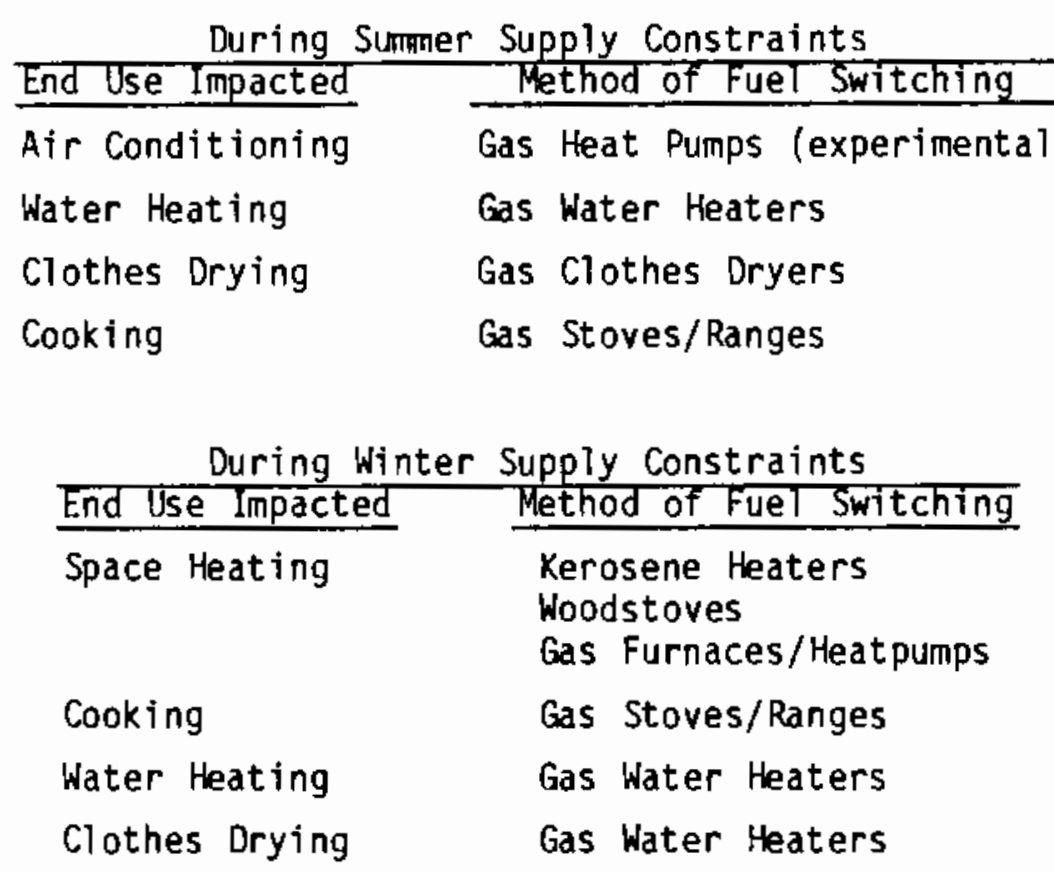

other situations, a substitute is available, but its adoption would predicate changes in end use behavior that may or may not be acceptable. A consumer's fuel choice is generally related to the type of equipment that they own. In the short run, consumers are locked into their stock of energy consuming equipment. In the long run, consumers may have the option of choosing to purchase equipment that uses some other fuel as an alternative to electricity. This equipment could either replace present appliances entirely or else it might be used in conjunction with present equipment as an auxiliary. The adoption of new equipment for use as an auxiliary to present appliances represents a move toward dual fuel capability.

This type of capability for heating is very common among households today a though it does not commonly exist for other end-uses. An estimated $37.8 \%$ of all households have some sort of auxiliary technology that allows them to use some fuel other than what is used for primary space heating requirements. Of single family households currently utilizing electricity as the primary space heating fuel, the percentage having some other capability is $51.9 \%$. Of this, all but $17 \%$ is comprised of other electricity using technologies, or of potential use of fireplaces. The remaining $17 \%$ is comprised of a number of options 
including woodstoves with $12 \%$, gas heaters with $1.5 \%$ and kerosene heaters with less than 1\% (DOE 1984b). In a supply constraint situation that was perceived as being permanent, the percentage of households with primary electric heating that would adopt dual fuel heating capabilities might increase considerably.

A decision to purchase new or additional nonelectric equipment in a supply constraint situation would be partially based upon the perceived value derived from present appliances that use electricity as an input and the lost value associated with interruptions of service. For example, when consumers decide to replace their heating system they may have a choice between equipment that uses different fuels (in certain parts of the country this choice is more limited than in others). Implicit in their decision is an assessment of the relative cost of the appliance over its lifetime including energy and maintenance costs, the appliance's attributes, the possible costs associated with expected electricity supply disruptions. If consumers perceive heating to be a high valued end use at the times of the expected disruptions they may choose a system that burns an alternative fuel even though the capital and operating costs may be higher.

\subsubsection{Discussion of Fuel Switching Options}

Although each of the options for fuel switching identified is technically feasible, there are considerations that would limit to varying degrees their application on a widespread basis. One consideration is the cost of the option both initially and during operations. Other considerations include the availability of the alternative fuel that each option uses, and the options' convenience and compatibility with the endusers' lifestyle.

One major impediment in the use of an alternative fuel is its availability, This is especially true with natural gas, a potential major substitute for electricity. In this case, the physical supply of the gas would probably not be an issue though the availability of hook-ups could serve as a limiting factor.

The remainder of this section will focus on a discussion of each of the methods for fuel switching we have identified. 


\subsubsection{Installation of Gas Furnaces and Heatpumps}

One possible mode of fuel switching that may have significant potential is the adoption of gas space heating and cooling technologies as an alternative to conventional electric furnaces, heatpumps, and air conditioners.

Of the gas technologies, gas heat pumps show substantial promise. This technology, which is presently undergoing development and is not expected to be commercially available for several more years, would be a potential substitute for both electric heating (for which gas furnaces al ready exist) and for air conditioning. One of the principle attractions of this option is that it should be extremely cost effective to operate. PNL recently completed a study for the US DOE that analyzed and projected the energy savings from ten new technologies including gas heatpumps. In this study, it was hypothesized that gas heatpumps would be considerably more expensive than conventional electric heatpumps initially, but that they would afford considerable cost savings in operational expenses through increased fuel efficiency. These operational cost savings would yield a first cost payback period of less than three years in new homes or replacement applications, and a payback period of 9 years in situations where a functional electric system is being retired early. Gas heatpumps were estimated to save a residential consumer approximately $75 \%$ of the estimated $\$ 585$ per year it costs to heat and cool an average home using an electric heatpump (MOE et al. 1986).

Conventional gas furnaces could also be used as a method of fuel switching. Gas furnaces generaliy prove to be more cost effective than electricity for heating though they would probably not be as cost effective as gas heatpumps.

Drawbacks associated with gas heatpumps and furnaces are related to the high incremental first cost over conventional electric technologies and the availability of natural gas hook-ups. An estimated $50 \%$ of new homes and $28 \%$ of all single family homes are unable to use natural gas because there are no gas lines serving the area (DOE 1981). In new or replacement situations, gas heat pumps do appear to have potential in those locations where gas hook ups are avail lable. 


\subsubsection{Installation of Gas Appliances}

This option involves the installation of gas cooking equipment, gas clothes dryers, and gas water heaters as substitutes for equivalent electric appliances. Installation can occur in replacement, early retirement (retrofit), and in new market situations. Gas appliances are generally more cost-effective to operate than electric appliances but are often more expensive initially.

According to the American Gas Association, the average yearly cost for operating a gas water heater is $\$ 173$ compared to $\$ 432$ for an electric water heater. For clothes drying, the average residential annual cost is $\$ 31$ for gas compared to $\$ 103$ for electricity. For cooking the average annual cost is $\$ 33$ for gas and $\$ 72$ for electricity. (a) These cost savings would make this option attractive to consumers that are replacing worn out equipment or are purchasing equipment for new applications as they would face only the incremental first cost differences between gas and electric appliances.

Mack and Gilmer (1983) estimated that the losses in consuiner welfare resulting from the disruptions of clothes drying, water heating, and, cooking are all less than $\$ .03$ per hour. If any of these functions were disrupted for ten periods of four hours each per year, the loss in welfare to an individual residential customer using the above estimate would be $\$ 1.20$ per year. Based on this estimate of lost welfare under our supply constraint scenario, there are probably very few consumers who would be willing to pay several hundred dollars to retrofit an existent functional appliance in order to mitigate this level of disruption cost. In new or replacement situations, the occurrence of electricity supply constraints, could play a contributory role toward influencing decisions to purchase gas appliances.

\subsubsection{Installation of Woodstoves and Fireplace Inserts}

Residential consumers with electric heating that are affected by electricity supply constraints might be willing to install woodstoves to act as either

(a) American Gas Association. 1984. Gas Consumption by Residential Appliances. 
a replacement or as a supplement to present heating systems. Airtight woodstoves that allow careful control of combustion can provide an effective method for residential heating. These stoves can be set to burn for up to 24 hours without reloading, while heating $1000-2000 \mathrm{sq} f t$ of floorspace.

The cost of installing an efficient airtight stove varies considerably depending on the brand, model, size, and building configuration. The cost of the special insulated flue pipe that is required in most jurisdictions often exceeds the cost of the stove. A total installed figure of $\$ 1000$ to $\$ 2500$ probably captures most set-ups. The cost of fire wood varies considerably depending on the wood, and the of area of the country.

Fireplace inserts effectively convert inefficient conventional fireplaces into more efficient woodstoves. As they vent directly into an existing chimney, they are considerably cheaper and easier to install than other types of woodstoves that require the purchase of flue pipe.

The use of woodstoves as a source of heating, has several drawbacks. The first involves convenience. Unlike other sources of residential heating such as electricity, gas, and, oi1, heating with wood requires careful attention and a fair amount of effort on a day to day basis. Woodstoves must be regularly stoked, cleaned, and monitored. Wood must be purchased, stored, and carried. In some parts of the country, particularly in urban areas, fire wood may be very expensive or virtually unobtainable. Woodstoves also present an imperfect substitute for central heating. Areas in a house that are close to a woodstove may be too warm while areas further away may be heated inadequately. Other drawbacks include difficulties with installation in some types of homes and communities, and an increase in fire risk.

At present approximately 4.8 million homes or almost $6 \%$ of total households use woodstoves as the primary method of heating. For them, wood provides a cost effective fuel for heating. However, because of inherent drawbacks, woodheating is probably limited to certain portions of the general population including those that live in rural areas or those that live a self-sufficient lifestyle. Oue to the great expense involved, the number of consumers that would install woodstoves solely as a response to suppiy constraints would be 
limited. Woodheating might gain in popularity among consumers that are considering this option for other reasons or as a supplementary heating source.

\subsubsection{Kerosene Heaters}

Kerosene room heaters could provide immediate and cost effective relief to electric heating system failure induced by electricity supply constraints. Used as an auxiliary to the central heating system, kerosene heaters can provide an immediate source of heat on short notice.

Unlike the other fuel switching options that we are examining, kerosene heaters do not require extensive initial cash outlays. The cost of units available, is between $\$ 50$ and $\$ 200$. A single heater can provide up to 20,000 Btu per hour, while heating up to $500 \mathrm{sq} f \mathrm{ft}$ for a period of 10-20 hours on a single 1-2 gallon fill up.

There are several outstanding disadvantages to kerosene heaters. Most significant are three major hazards: they give off potentialiy hazardous fumes, they present a burn hazard, and they pose a distinct fire hazard if knocked over. (a) In addition even when not hazardous, the fumes that the heaters put off may be found offensive by a substantial portion of potential customers. Therefore although kerosene heaters are quite cost effective, they would probably have only moderate potential as an acceptable fuel switching option due to health and safety drawbacks.

\subsubsection{Potential Peak Demand Reduction}

All the methods we examined for fuel switching in response to service disruptions caused by electricity supply constraints seem to have some potential. In estimating potential reductions in peak demand, we first sought case studies of consumers adopting fuel switching strategies.

There is relatively little information about consumer's willingness to switch from electricity to an alternative fuel in response to electricity supply constraints. Because significant electricity supply constraints have not yet developed, consumers have not been prompted to switch from electricity

(a) Consumer Reports, October 1985. 
to other fuels to increase service reliability. Some electric utilities that have sought to limit peak demand have promoted the sale of more efficient electric appliances by offering rebates to consumers.

Each of the options that was found to have potential, would be significantly more expensive on a per $k$ Wh basis than the estimates for the cost of outages to residential consumers presented in Chapter 2.0 of this report. In short, consumer acceptance of switching fuels may be unattainable unless proper financial inducements are offered. For a consumer to take the initiative to purciase an appliance that uses a fuel other than electricity they must value peak consumption at a sufficient level to justify the costs of switching. However, if a consumer is replacing an appliance because it is worn out or is installing an appliance in a new home, the costs of switching fuels is mitigated to a certain extent.

In estimating the potential for these fuel switching options we assumed that they are being adopted primarily in new or replacement situations. It was necessary to make a large number of simplifying assumptions in estimating the potential for peak demand reductions. Therefore, these estimates should be viewed as rough and used only as a guide to what the reductions would likely be under one set of assumptions.

Potential peak reductions from the adoption of gas neatpumps are presented in Table 3.17. These estimates are based on projections presented in The Electric Energy Savings from Ten New Technologjes (MOE et a1. 1986). The number of

TABLE 3.17. Potential Peak Reductions from Adoption of Gas Heatpumps as a

\begin{tabular}{|c|c|c|c|c|c|c|}
\hline Yeor & $\begin{array}{l}\text { Installations } \\
\text { for Heatling }\end{array}$ & $\begin{array}{l}\text { Installations } \\
\text { for Cooling }\end{array}$ & $\begin{array}{l}\text { Per Polnt } \\
\text { Loed } \\
\text { Reduct Ion } \\
\text { Hesting (k-1) } \\
\end{array}$ & $\begin{array}{c}\text { Per Polnt } \\
\text { Load } \\
\text { Reduction } \\
\text { Cooling (ki) } \\
\end{array}$ & $\begin{array}{l}\text { Total } \\
\text { Load } \\
\text { Reduction } \\
\text { Heat Ing } \\
\text { (Gw) } \\
\end{array}$ & $\begin{array}{l}\text { Total } \\
\text { Losd } \\
\text { Reduction } \\
\text { Cool Ing } \\
\text { (GW) }\end{array}$ \\
\hline 1990 & 4,000 & 19,000 & 5 & 4.3 & 0.02 & 0.08 \\
\hline 1995 & 270,000 & $1,320,000$ & 5 & 4.3 & 1.4 & 5.72 \\
\hline
\end{tabular}

(a) Estimates from tho et al. 1986. 
projected installations is based on estimates for installations in new homes and for replacing worn out equipment. The assumed per point reduction in cooling demand of $4.3 \mathrm{~kW}$ is based on a national average $\mathrm{k} k$ per unit presented earlier in this chapter. The assumed per point reduction in heating of $5 \mathrm{~kW}$ is based on the expert judgment of PNL staff familiar with residential energy usage. Using these assumptions led to estimates of reductions in winter peak demand from heating of 0.02 GW in 1990, and of 1.4 GW in 1995. Summer reductions in cooling (air conditioning) were estimated at 0.08 GW in 1990 and 5.72 GW in 1995. The large jump in projected savings over the 1990 to 1995 time frame is based on expectations that few systems would be installed in 1990 due to the product's newness. Large summer reductions relative to those of winter reflect, the large market share that electricity has for cooling relative to its share for heating.

In order to estimate potential peak reductions from the adoption of gas appliances as a replacement for their existing electric counterparts, we multiplied the projected housing stock for both 1990 and 1995 by the estimated market penetration rate for the option. We estimated this rate at $2 \%$ for 1990 and $3 \%$ for 1995 . The penetration rate selected was low because the option is not very cost effective compared to estimates of the cost of outages to consumers. At the same time, we anticipate that a small portion of the general population may find this option cost effective or may select this option to reduce their exposure to energy shortages. Per point reductions of $0.5 \mathrm{~kW}$ were chosen as the average peak demand for water heaters, clothes dryers, and ranges. Potential reductions in peak demand of $0.96 \mathrm{GW}$ for 1990 and of $5.56 \mathrm{GW}$ for 1995 are presented in Table 3.18 .

TABLE 3.18. Potential Peak Reductions from Adoption of Gas Appliances as a Method of Fuel Switching

\begin{tabular}{|c|c|c|c|c|c|}
\hline Year & $\begin{array}{l}\text { Total } \\
\text { Households } \\
\text { (millions) }\end{array}$ & $\begin{array}{l}\text { Penetration } \\
\text { Rate for } \\
\text { Option }(\%)\end{array}$ & $\begin{array}{l}\text { Households } \\
\text { Adopting Option }\end{array}$ & $\begin{array}{l}\text { Per Point } \\
\text { Reduction }(\mathrm{kw})\end{array}$ & $\begin{array}{c}\text { Total } \\
\text { Reduction (GW) }\end{array}$ \\
\hline 1990 & 96.3 & 2 & $1,930,000$ & 0.5 & 0.96 \\
\hline 1995 & 104.1 & 3 & $3,120,000$ & 0.5 & 1.56 \\
\hline
\end{tabular}


Potential peak reductions from the adoption of woodstoves were estimated by first estimating the number of installations for both 1990 and 1995. This was accomplished by multiplying projections of the mimber of homes with electric heating for 1990 and 1995 by estimates of market penetration for woodstoves of $3 \%$ and $4 \%$ respectively. Peak reductions were derived by multiplying these numbers by an assumed per point peak load reduction of $5 \mathrm{~kW}$. This reduction is comparable to assumed reductions used to estimate reductions from gas heatpumps. The total derived reductions of $2.9 \mathrm{GW}$ in 1990 and $4.78 \mathrm{GW}$ in 1995 are presented in Table 3.19 .

Table 3.20 presents the total estimated peak reductions from kerosene heaters of $0.4 \mathrm{GW}$ in 1990 and $0.7 \mathrm{GW}$ in 1995. These values were derived by multiplying the projected housing stock with electric heating for 1990 and 1995 by our market penetration estimates of $2 \%$ and $3 \%$ respectively. An average per point reduction of $1 \mathrm{kN}$ is assumed, reflecting that kerosene heaters substitute for portable electric heaters of $1.5 \mathrm{~kW}$ or less.

TABLE 3.19. Potential Peak Reductions from Adoption of Woodstoves as a Method of Fuel Switching

\begin{tabular}{|c|c|c|c|c|c|}
\hline Year & $\begin{array}{l}\text { Households with } \\
\text { Electric Heat } \\
\text { (millions) }\end{array}$ & $\begin{array}{l}\text { Penetration } \\
\text { Rate for } \\
\text { Option (x) }\end{array}$ & $\begin{array}{l}\text { Households } \\
\text { Adopting } \\
\text { Option }\end{array}$ & $\begin{array}{l}\text { Per Point } \\
\text { Reduction }(\mathrm{kw})\end{array}$ & $\begin{array}{l}\text { Per Point } \\
\text { Reduction (GW) }\end{array}$ \\
\hline 1990 & 19.3 & 3 & 580,000 & 5 & 2.9 \\
\hline 1995 & 23.9 & 4 & 956,000 & 5 & 4.78 \\
\hline
\end{tabular}

TABLE 3.20. Potential Peak Reductions from Adoption of Kerosene Heaters as a Method of Fuel Switching

\begin{tabular}{|c|c|c|c|c|c|}
\hline Year & $\begin{array}{l}\text { Households with } \\
\text { Electric Heat } \\
\text { (millions) }\end{array}$ & $\begin{array}{l}\text { Penetration } \\
\text { Rate for } \\
\text { Option ( })\end{array}$ & $\begin{array}{l}\text { Households } \\
\text { Adopting } \\
\text { Option }\end{array}$ & $\begin{array}{l}\text { Per Point } \\
\text { Reduction }(\mathrm{kw})\end{array}$ & $\begin{array}{l}\text { Per Point } \\
\text { Reduction (GW) }\end{array}$ \\
\hline 1990 & 19.3 & 2 & 386,000 & 1 & 0.4 \\
\hline 1995 & 23.9 & 3 & 717,000 & 1 & 0.7 \\
\hline
\end{tabular}


Total estimates for the adoption of atl of the above options are presented in Table 3.21. Estimates for summer reductions were derived by adding estimates for gas heatpump cooling and adoption of gas appliances. For winter, reductions were calculated by summing the estimates for gas heatpump heating, gas appliances, woodstoves, and kerosene heaters. These summations yielded estimated reductions for winter equal to 4.28 GW and 8.44 GW and estimated reductions for summer equal $1.04 \mathrm{GW}$ and $7.28 \mathrm{GW}$ for 1990 and 1995. These estimates should be regarded as providing an upper bound for potential peak demand reduction. Assumptions on both market penetration and per point reductions were chosen based on the best available information though they may be overly optimistic. In addition some amount of double counting may have occurred as customers that adopt one option would probably not adopt another, and therefore should have been subtracted out of the population totals.

\subsection{SUMMARY OF FINDINGS}

A number of options are available to the consumer to lessen the impacts of an electricity supply disruption. Five possible response areas were identified and discussed in this chapter. These areas included time-of-use rates, fuel switching, thermal energy storage, more efficient appliances, and direct load control. Table 3.22 gives a brief overview of the latter three response areas

TABLE 3.21. Total Potential Peak Reductions from Adoption of Various Methods of Fuel Switching

\begin{tabular}{|c|c|c|}
\hline Year & $\begin{array}{l}\text { Total } \\
\text { Winter Pegk } \\
\text { Reduction a) } \\
\end{array}$ & $\begin{array}{l}\text { Total } \\
\text { Summer Peak } \\
\text { Reduction }(b) \\
\end{array}$ \\
\hline 1990 & $4.28 \mathrm{GW}$ & $1.04 \mathrm{GW}$ \\
\hline 1995 & 8.44 GN & $7.28 \mathrm{GW}$ \\
\hline
\end{tabular}

(a) Calculated as the sum of reduc. tions from gas heatpump heating + gas appliances + woodstoves + kerosene heaters.

(b) Calculated as the sum of reductions from gas heatpump cooling + gas appliances. 
TABLE 3.22. Review of Primary Response Areas for the Residential Sector

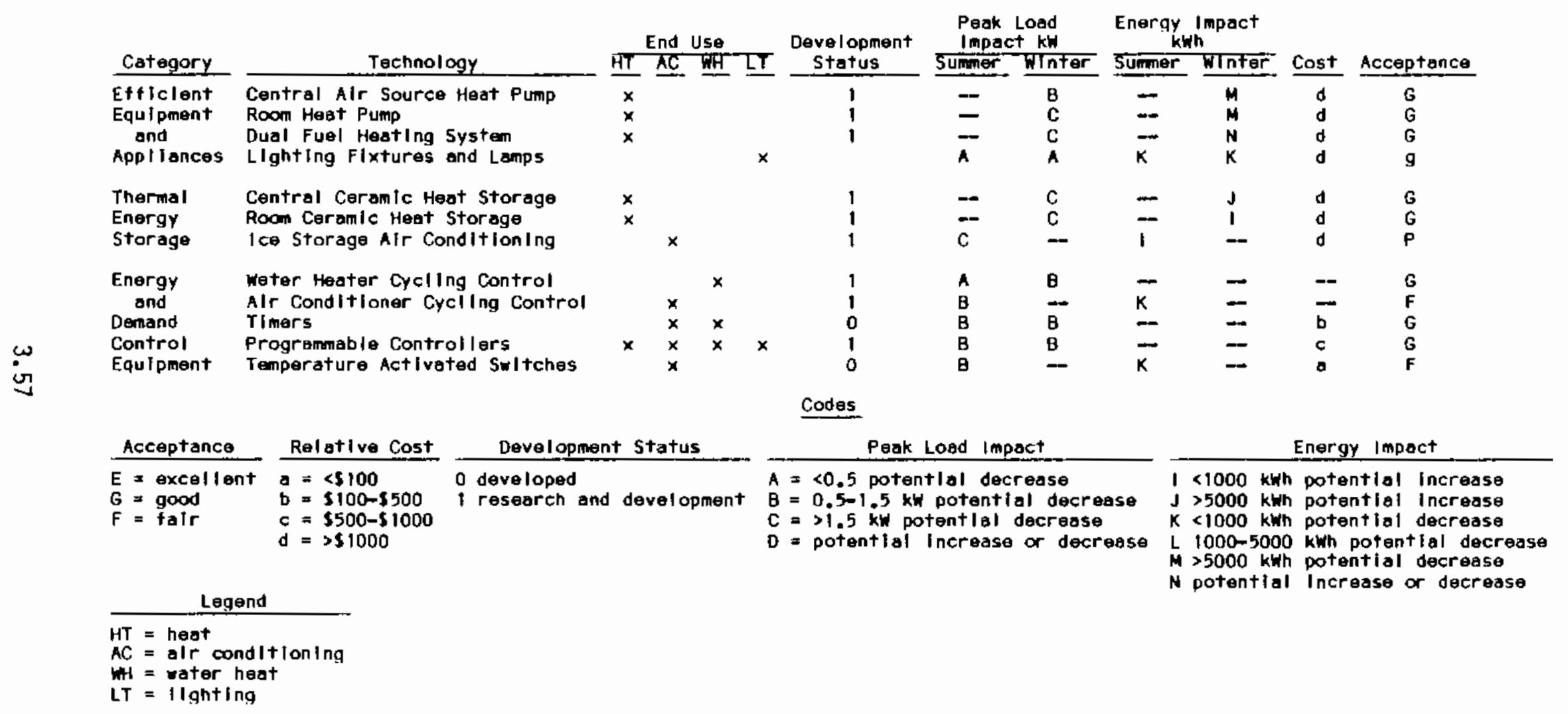


by indicating the end use best served by each technology, the development status of each technology, the peak demand reduction in $\mathrm{kW}$ and $\mathrm{kWh}$ for both the winter and summer season, the relative cost to the consumer and the customer acceptance based on previous experience.

Electricity demand in the residential sector varies substantially among households depending upon a wide array of parameters, some of which include appliance holdings, demographic characteristics, income and the price of alternative fuels. Consequentiy, response to an electricity shortfall will be determined by the individual household. The potential savings discussed in this chapter are based upon the average response from a host of studies and provide only raw estimates. In appiying these responses to a specific group of consumers it is important to remember the relative attractiveness of each alternative response will depend upon the consumers' preferences, which are not homogeneous across households. For example, an air conditioner cycling program is unlikely to appeal to those who put a premium upon the basic need to retain control of their environment and lifestyle. These customers may be happier with TOU rates. On the other hand, customers that are more concerned with reducing their monthly bill and put a low premium on retaining control may be better served by a DLC program. End use saturation levels are often quite different, even for utilities in the same geographic area. Thus, white the impact of an alternative may be the same on a per-unit basis, the total impact resulting from the same saturation may be quite different. Table 3.23 gives a summary of the potential GW savings in 1990 and 1995 by response area and end use. 
Table 3.23. Summary of Potential National Peak Demand Reduction by Response Area (GW)

\begin{tabular}{|c|c|}
\hline Response Area & 1990 \\
\hline $\begin{array}{l}\text { Shifting the timing of } \\
\text { demand in response to time } \\
\text { of use rates. } \\
\text { - Winter } \\
\text { - Summer }\end{array}$ & $\begin{array}{l}1.6 \\
3.2\end{array}$ \\
\hline $\begin{array}{l}\text { Thermal Energy Storage } \\
\text { - Space Heat } \\
\text { - Air Conditioning }\end{array}$ & $\begin{array}{l}1.4 \\
5.1\end{array}$ \\
\hline $\begin{array}{l}\text { Enerqy efficient appliances } \\
\text { - Heating } \\
\text { - Water Heating } \\
\text { - Air Conditioning }\end{array}$ & $\begin{array}{l}1.8 \\
1.7 \\
2.9\end{array}$ \\
\hline $\begin{array}{l}\text { Direct Load Control } \\
\text { - Heating } \\
\text { - Air Conditioning } \\
\text { - Water Heating }\end{array}$ & $\begin{array}{l}1.3 \\
3.1 \\
1.7\end{array}$ \\
\hline $\begin{array}{l}\text { Fuel Switching } \\
\text { - Winter } \\
\text { - Summer }\end{array}$ & $\begin{array}{l}4.3 \\
1.0\end{array}$ \\
\hline
\end{tabular}

\subsection{REFERENCES}

Central Illinois Light Company. 1982. Residential Time-of-Use Information. Peoria, Illinois.

Cobb Electric Membership Corporation. 1982. Load Management Program: Application and Results in an On-going Program. Marietta, Ceorgia.

Consumer Reports. 1985. "Winter Energy Savings." Consumer Reports. Vo l. 50 No. 10.

EPRI. 1983. Energy Use and Customer Welfare Effects of Residential Time of Use Rates. EA-2832, Electric Power Research Institute, Palo Alto, California.

EPRI. 1984. Survey of Utility End Use Projects. EA-3529, Electric Power Research Institute, Palo Alto, California.

Geller, Howard S. 1983. Energy Efficient Appliances. American Council for an Energy-Efficient Economy, Washington D.C. 
Gilmer, R. 1982. The Cost of Electric Power Interruptions to Residences in the Tennessee Valley. Oak Ridge Associated Universities, Oak Ridge,

Tennessee.

Gilmer, R. W. and R. S. Mack. 1983. "The Cost of Residential Electric Power Outages." The Energy Journa1, Vo1. 4 No. 3.

Green Mountain Power Corporation. 1977. Final Report: Investigations into the Effects of Rate Structures on Customers Electric Usage Patterns. Burlington, Vermont.

Hastings, B. E. 1980. A Method for Calculating Direct Operating Load Management Benefits from Thermal Storage Devices. institute of Electrical and Electronics Engineers, New York.

Hastings, B. E. 1984. Ten Years of Operating Experience with a Remote Controlled Water Heater Load Management System. Detroit Edison Co., Detroit Michigan.

Huettner, D, et al. 1982. "Costs and Benefits of Residential Time of Use Metering." The Energy Journal.

IEEE. 1985. Integrating Load Management into Utility Planning. 85-wM-032-8, Institute of Electrical and Eectronics Engineers, Inc., New York.

Itteilag, R. L. 1984. "A Life Cycle Analysis of Residential Gas-Fired Heat Pumps." Public Utilities Fortnight ly, May 10, 1984.

Juracek, Arlene A. 1982. "Description and Results of Commonwealth Edison's Residential Air Conditioning Control Experiment." Presented at the American Power Conference. April 26-28, 1982.

Kuliashu, M. 1983. Utility Controlled Customer-Side Thermal Energy Storage Tests. ORNL-5795, Oak Ridge National Laboratory, Oak Ridge, Tennessee.

Lovins, Amory B. 1984. Least-Cost, Reliable Electrical Services as an Alternative to Seabrook. Direct testimony before the Public Utilities Comnission, State of New Hamphire.

Mathiason, D. 1984. "Superinsulations Robust Future." Public Power, September-October, 1984.

Moe, R. J. et al. 1986. The Electric Energy Savings from new Technologies. PNL 5665, Pacific Northwest Laboratory, Richland, Washington.

Oglethorpe Power Company. 1980. Excerpts from the Feasibility Study for the Design of a Statewide Load Management Data Acquisition and Control System. Tucker, Georgia. 
O'Rourke, P. and F. L. Schweppe, 1982. Space Conditioning Load Under Spot or Time of Day Pricing. Massachusetts Institute of Technology, Boston, Massachusetts.

Potomac Electric Power Co. 1984. Energy Management Series. Introduction to Time-of-Day Monitoring: Report for the 1983 Summer Season. Washington D.C.

Public Service Company of Colorado. 1981. Comparison of Residential Heating Customers On Demand and Non-Demand Rates. Denver, Colorado.

Public Service Company of Colorado. 1984. Public Service Company of Colorado Time-of-Day Monitoring Report for the 1983 Summer Season. Denver, Colorado.

Sanghvi, A. P. 1982. "Economics Costs of Electricity Supply Interruptions." Energy Economics.

Tennessee Valley Authority. 1982. Water Heating/Space Conditioning Control Test 1979/1981, Final Report.

Thomas, J. C. 1981. Test Results of Twelve Residential Heat Pumps in Anniston, Alabama. Alabama Power Co., Birmingham, Alabama.

U.S. DOE. 1983. Residential Energy Consumption Survey Housing Characteristics. DOE/EIA-D314, Department of Energy, Washington D.C.

U.S. DDE. 1983. The Future of Eectric Power in America: Economic Supply for Economic Growth. DOE/PE-0045, Department of Energy, Washingt on D.C.

U.S. DOE. 1984. Annual Energy Qutlook 1984 with Projections to 1995. DDE/EIA-0383, Department of Energy, Washington D.C.

U.S. DOE. 1984. Residential Energy Consumption Survey: Consumption and Expenditures Apri1 1983 Through March 1983. DOE/E IA-0321/2, Department of Energy, Washington D.C.

U.S. DOE. 1985. Annual Energy Outlook 1984 with Projections to 1995. DOE /EIA-0383, Department of Energy, Washington, D.C.

Verrips, A. M. 1984. "Natural Gas vs. Heat Pumps." Public Power, July-August 1984.

Wi11, C. F. 1983. First Year Test Results of an E-Tech Heat Pump Water Heater in Burmingham, Al abama. Energy Services, Alabama Power Co., Birmingham, Alabama.

Wi11, C. F. 1983. Test Results of an E-Tech Heat Pump Water Heater Metered with a BTU Meter. Energy Services, Alabama Power Co., Birmingham, Alabama. 

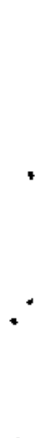


\subsection{INDUSTRIAL SECTOR RESPONSE TO ELECTRICITY SUPPLY CONSTRAINTS}

In 1983 the U.S. industrial sector consumed approximately 776 billion kilowatt hours (kWh) of electricity. This was $36 \%$ of the estimated U.S. total consumption, making the industrial sector the largest end user of electricity (DOE 1984). Table 4.1 shows the consumption of electricity by the industrial

TABLE 4.1. Estimated Purchased and Self-Generated Electricity for 1981

\begin{tabular}{|c|c|c|c|c|}
\hline $\begin{array}{l}S 1 C^{(a)} \\
\text { Code }\end{array}$ & Industry Group and Industry & $\begin{array}{c}\text { Purchased } \\
\text { Quantity } \\
\text { (million kwh) }\end{array}$ & $\begin{array}{l}\text { Generated (b) } \\
\text { Less Sold } \\
\text { (million kwh) } \\
\end{array}$ & Total \\
\hline & All Industries & $665,784.4$ & $54,856,8$ & $720,641,2$ \\
\hline 20 & Food and klndred products & $41,428.0$ & $2,089,4$ & $43,517,4$ \\
\hline $2 t$ & Tobacco products & $1,422,0$ & (c) & $1,422,0$ \\
\hline 22 & Textlle mill products & 25.579 .5 & 341.8 & $25,921,3$ \\
\hline 23 & Apparel and other textile products & $6,056.7$ & (d) & $6,056,7$ \\
\hline 24 & Lumber and wood products & $14,527.7$ & 245.6 & $14,733.2$ \\
\hline 25 & Furntture and fixtures & $4,143.2$ & $(d)$ & $4,143.2$ \\
\hline 26 & Paper and allied products & $52,198.8$ & $26,529.9$ & $78,728,7$ \\
\hline 27 & Printing and publishing & $10,302.3$ & (d) & $10,302.3$ \\
\hline 28 & Chemleals and allied products & $132,339.5$ & $10,198.3$ & $142,537.8$ \\
\hline 29 & Petroleum and coal products & 32.546 .1 & $5,437.0$ & $37,983.1$ \\
\hline 30 & Rubber and miscellaneous plastics products & $22,913.3$ & 44.1 & $22,957.4$ \\
\hline 31 & Lesther and leather products & $1,320.5$ & 5.7 & $1,326.2$ \\
\hline 32 & Stone, clay, and glass products & $30,063.9$ & 292.6 & $30,356.5$ \\
\hline 33 & PrImary metal Industrles & $165,959.4$ & $9,058.0$ & $175,017.4$ \\
\hline 34 & Fabrlcated metal products & $25,539.1$ & (d) & $25,539.1$ \\
\hline 35 & Machlnery, except electrical & $31,569.1$ & 126.9 & $31,696.0$ \\
\hline 36 & Electric and electron le equipment & $28,027.0$ & 126.9 & $28,065.8$ \\
\hline 37 & Transportation equipment & $30,090.5$ & (d) & $30,090.5$ \\
\hline 38 & instruments and related products & 6.127 .5 & (c) & $6,127.5$ \\
\hline 39 & MIscellaneous manufacturling & 630.8 & 14.4 & $3,635.2$ \\
\hline
\end{tabular}

Source: Bureau of the Census 1982.

(a) Standard industrial Classification (SIC).

(b) This category Includes only that portion of self-generated electrlcity consumed by the generating firm.

(c) Quantity withheld to avoid disclosing proorletary information.

(d) Withheld because estimate did not meet standards of consistency. 
sector among two digit Standard Industrial Classification (SIC) groups 1981. These estimates are based upon responses to Bureau of the Census' Survey of Manufacturers on each groups energy use and include purchased and selfgenerated electricity. Chemicals, petroleum, paper, and metals stand out as the big electricity users.

\subsection{INDUSTRIAL ELECTRICITY CONSUMPTION 1985-1995}

Industrial sector electricity consumption has been steadily rising during the post war period with the exception of a minor drop during the early 1980's (DOE 1984). Electricity consumption is expected to continue to rise during the 1980 's and into the 1990's (DOE 1983a). This trend is in part due to the high efficiency of electricity for use in industrial processes in spite of a relatively high cost per Btu in comparison to other fuels. During the period of 1973 to 1980, industrial electricity demand grew at an average annual rate of growth of 2.5\% (DOE 1983a). Assuming a similar rate of growth, 1990 industrial sector consumption would rise 13\% over the 1985 level and consumption in 1995 would be $27 \%$ above that of 1985 .

Electricity consumption by the industrial sector for 1990 and 1995 will be the result of a number of basic factors:

- the size of the economy,

- the composition of the economy,

- the level of industrial output,

- changes in technology,

- relative energy prices,

- changes in the energy use intensity per dollar of industrial output, and

- the share of electricity among total energy use.

Industrial sector electricity consumption has risen steadily as a percentage of total energy use since the $1960^{\prime} \mathrm{s}$. Despite a general decline in total energy use per unit of industrial output, electricity use as measured per unit has remained fairly stable. In 1983, electricity use accounted for $14 \%$ of the 
total industrial energy use. By 1995 this portion should rise to about $18 \%$ (DOE 1984). Factors contributing to this projected increase include, economic growth and new and improved processes such as the use of microwaves for induction heating, robotics and electrochemical devices.

Electricity consumption forecasts for the industrial sector are often regarded as the least reliable compared to other sectors due to the complexity and heterogeneity of the industrial sector. Using two widely different models, the Oak Ridge Industrial Model (ORIM) and the Industrial Sector Technology Use Model (ISTUM-2), the DOE Office of Policy, Planning and Analysis generated two projections for annual industrial electric growth (DOE 1983a). Table 4.2 outlines the historical and projected relationship between GNP growth and industrial demand growth from both of these models.

For the 1980 to 1990 period, ORIM and ISTUM-2 forecast electric demand growth at 1.0 and .7 times the rate of GNP growth respectively. This represents a continuation of the trend during the early 1980's of low annual growth in industrial electric demand. This may be partly due to increases in the adaptation of energy conservation methods and processes. For 1990 to 2000, the models call for ratios of industrial electric growth to GNP growth of 1.5 to 1.7 respectively.

Assuming a 2.8\% annual GNP growth rate, the models project annual industrial electric demand growth at 2.8\% (ORIM) and 2.0\% (ISTUM). These low rates of electric demand growth relative to the historical rates reflect that the 1980 's are expected to be a period of continued adjustment to the major energy price shifts of the 1970's by the industrial sector. The use of lower or higher GNP growth assumptions such as the $3.9 \%$ annual rate cited in The Economic Report of the President, (1985) would affect these projections considerably.

For the 1990 to 2000 period a $2.2 \%$ annual GNP growth rate is assumed. Based on this the ISTUM-2 model projects $3.3 \%$ growth in industrial electric demand while the ORIM model projects $3.7 \%$ growth. This would indicate a renewal of industrial electric growth demand resulting from the exhaustion of 
TABLE 4.2. Historica! and Projected Relationship Between GNP Growth and Industrial Electric Demand Growth, 1951-2000(a)

\begin{tabular}{|c|c|c|c|c|}
\hline & $1951-1973$ & 1973-1980 & $1980-1990$ & $1990-2000$ \\
\hline $\begin{array}{l}\text { Average annual } \\
\text { GNP growth rate }\end{array}$ & $3.51 \%$ & $2.36 \%$ & $2.8 \%$ (DRI est.. $^{(b)}$ & $2.2 \%$ (DRI est.) $^{(b)}$ \\
\hline $\begin{array}{l}\text { Average annual } \\
\text { growth in } \\
\text { industrial } \\
\text { electrical } \\
\text { demand }\end{array}$ & $6.45 \%$ & $2.46 \%$ & $\begin{array}{l}2.0 \% \text { (ISTUM-2 } \\
\text { projection) }(c, d) \\
2.8 \% \text { (ORIM } \\
\text { projection) }(c, d)\end{array}$ & $\begin{array}{l}3.3 \% \text { (ISTUM-2 } \\
\text { projection) }(c, d) \\
\text { 3.7\% ORIM } \\
\text { projection) }(c, d)\end{array}$ \\
\hline $\begin{array}{l}\text { Ratio of indus- } \\
\text { rial electric } \\
\text { growth/GNP } \\
\text { growth }\end{array}$ & $1.84 \%$ & $1.04 \%$ & $\begin{array}{l}0.7 \% \text { (ISTUM-2 } \\
\text { projection) }(c, d) \\
1.0 \%(\text { ORIM } \\
\text { projection) } \\
(c, d)\end{array}$ & $\begin{array}{l}1.5 \% \text { (ISTUM-2 } \\
\text { projection) }(c, d) \\
1.7 \% \text { (ORIM } \\
\text { projection) }(c, d)\end{array}$ \\
\hline
\end{tabular}

(a) Source: DOE 1983b, Mathtech 1983.

(b) To generate industrial electric demand projections, Mathtech used DRI's long-term mid-range economic forecast (Data Resources, Inc., Trendlong 2007A, Spring 1982).

(c) The prices used for delivered energy in the industrial sector were the same for both the ISTUM-2 and ORIM projections; i.e., DOE's Low World 011 Price projection, as published in the 1981 Annual Report to Congress, Vol. 3, Table 3.2.

(d) The projected figures are mid-range point estimates from two very different mode1s; accordingly, they should not be regarded as bounding a plausible range of estimates, and any attempt to interpolate between them is inappropriate.

economically viable opportunities to improve the efficiency of electric consumption. Based on these projections, Table 4.3 summarizes the expected demand for electricity by the industrial sector for 1990 and 1995 . These projections are roughly equivalent to other projections for $U$. S. industrial electricity demand for the year 1990 as outlined in the Annual Energy Outlook of 1983 (1984) and shown in Table 4.4.

4.1.1 Industrial Sector Peak Demand

As our anaiysis of industrial response to electricity supply constraints focuses on capacity constraints, it is necessary to quantify electrical usage 
TABLE 4.3. Expected Electricity Demand for the Industrial Sector, 1980, 1990, 1995 (billion kWh)

\begin{tabular}{|c|c|c|c|}
\hline Year & $\begin{array}{l}\text { Actual } \\
\text { Demand }\end{array}$ & $\begin{array}{c}\text { ORIM } \\
\text { Projection }\end{array}$ & $\begin{array}{c}\text { ISTUM-2 } \\
\text { Projection }\end{array}$ \\
\hline 1980 & 815 & -- & -- \\
\hline 1990 & -- & 1022.8 & 945.9 \\
\hline 1995 & - & 1226.5 & 1112.6 \\
\hline
\end{tabular}

(a) Actual demand based on utility sales to the Industrial Sector from DOE. $1984 b$.

(b) ORIM and ISTUM-2 projection based upon the above and rates of electricity demand growth outlined in DOE 1983b.

TABLE 4.4. Expected Electrical Demand for the Industrial Sector in 1990

\begin{tabular}{|c|c|}
\hline Projection & $\begin{array}{l}\text { U.S. Indust } \\
\text { Electrical De } \\
1990 \text { (billio }\end{array}$ \\
\hline Annual Energy Outlook 1984 & \\
\hline Annual Energy Outlook 1983 & 1025 \\
\hline Annual Energy Outlook 1982 & 1113 \\
\hline Data Resources, Inc., Winter $82 / 83$ & 1055 \\
\hline $\begin{array}{l}\text { Chase Econometrics Associates } \\
\text { Energy Analysis Quarterly } 1983 \text { IV }\end{array}$ & 1025 \\
\hline NEPP 1983 & 1025 \\
\hline
\end{tabular}

on a peak-demand (kW) basis that is likely to be subject to these constraints. To calculate peak demand we use the estimates of electricity demand shown in Table 4.3 .

Dividing the 776 billion kilowatt-hours demanded by the industrial sector during 1983, by 8760 (the number of hours per year) gives us an average demand of 88.58 Gigawatts (GW). This concept of average demand is not directly useful to our analysis since electric demand varies on a daily and seasonal basis.

A useful way to derive levels of peak demand (kw) from the quantity of electric usage (kWh) is with the concept of load factor. Load factor is 
obtained by dividing the average demand (see above) by the peak demand. Load factors can take on values between 0 and 1 . Values close to 0 indicate that demand over a period of time is subject to wide levels of fluctuation. Values close to 1 indicate that demand is fairly constant.

In general, the industrial sector can be characterized as having a fairly high load factor. This is due in part to a generally high rate of continuous production. Many large industrial electricity consumers operate their plant and machinery almost around the clock throughout the year in order to maximize profits and make the best use of capital equipment. Four industries: paper and allied products (SIC 26), (a) chemicals (SIC 28), petroleum and coal (SIC 29) and primary metals (SIC 33) comprise over half the demand for purchased electricity within the industrial sector (Bureau of the Census, 1982). When business is good, firms within these industries typically operate at contỉnuous levels, maintaining fairly even electric demand (OTA 1983).

The economy as a whole has a load factor of about 0.62 (NERC 1984). Unfortunately, we were unable to locate data on load factors for separate sectors of the economy. Load factors for both the commercial and residential sectors are significantly lower than the industrial sector hecause of sharp spikes in demand caused by hot spells in the summer and cold spells in the winter. We assume that the industrial sector has a load factor of about 0.75 to off-set the lower values for the other sectors. (This is a conservative assumption; for some industries, load factors can be as high as 0.9 during periods of economic expansion.)

Based on this value, we can estimate industrial sector peak demand for 1983 of 118.4 GW. Using the assumed value for industrial load factor and further assuming that it remains constant, we can estimate peak demand based upon forecasted industrial sector for electricity demand from the ORIM and ISTUM-2 models. This is shown in Table 4.5.

(a) Standard Industrial Classification. 
TABLE 4.5. Estimated Industrial Peak Electric Demand (GW)

$\begin{array}{lll}\frac{\text { Year }}{1990} & \frac{\text { ORIM }}{155.7} & \frac{\text { ISTUM-2 }}{144.0} \\ 1995 & 187.6 & 169.3\end{array}$

\subsection{REDUCING THE LEVEL OF ELECTRICITY USE IN RESPONSE TO SUPPLY CONSTRAINTS}

A possible response to electricity supply constraints by the industrial sector is the voluntary reduction of demand during times when electricity is unavailable. Currently, many industrial users of electricity have entered into agreements with utility companies calling for lower rates in exchange for an agreement to curtail demand for specified time periods.

\subsubsection{Interruptible Rates}

In return for lower rates, interruptible customers agree to periodically limit their load at times of utility system need. Specific agreements differ on the number of interruptions allowed, the minimum amount of warning time to be given to the customer before interruption, the maximum length of time per interruption, and the specific terms of renumeration to be paid to customers participating in the program.

Some utilities distinguish between interruptible rates and curtailable rates. Curtailments differ from interruptions in the level of service disruption. Inder curtailable rates, users have greater flexibility in responding as they are required to shut down part of their load. Under interruptible rates, a designated load is shut down completely, leaving users with less response flexibility.

For the most part, firms that engage in continuous processes or those with nearly flat load curves suffer greater damage from interruption than firms that produce in batches or have idle plant and equipment. Also, certain types of load can be shed at lower costs than others. At the low end of the spectrum are space conditioning and processes that are either nonessential or can be rescheduled or delayed. At the high end of the spectrum are portions of load 
going for essential lighting or safety equipment, In between the low and high end are those production processes that directly affect the company's bottom line.

Figure 4.1 shows the costs suffered by an imaginary firm associated with the loss of power due to capacity constraints. Different portions of a firms power load go toward different end uses. At the left end of the $x$ axis, the cost per $\mathrm{kW}$ is relatively small because less vital activities have been shut off. As we move to the right along the $x$ axis, more vital activities have been discontinued as the cost of each additional block of load is of higher value than the previous block. A firm considering an interruption agreement will want to be compensated above the level of damage incurred by the loss of the power.

In general, a utility offering interruptible agreements wants to minimize the cost per $\mathrm{kW}$ it pays the customer. In order to compensate a fim to curtail its entire load, the utility would end up paying more on a per kW basis than if

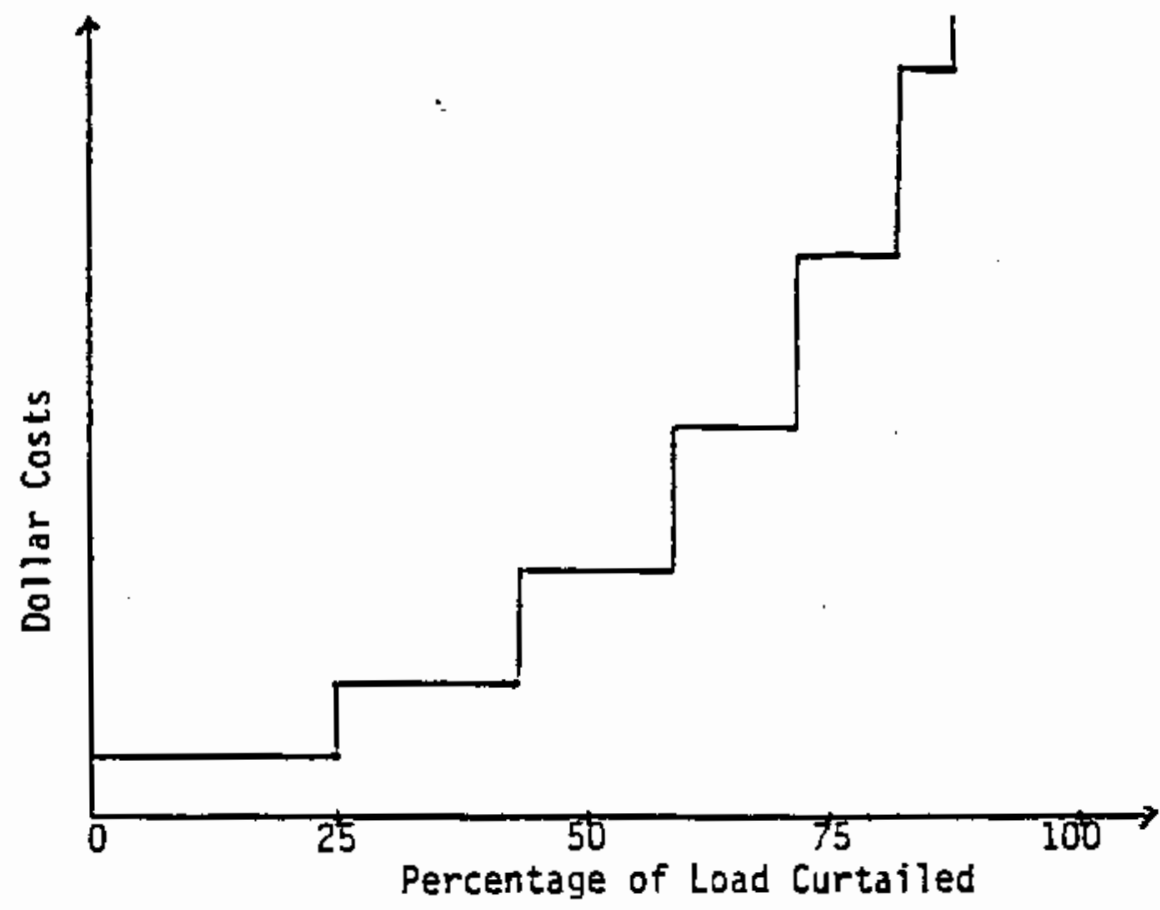

FIGURE 4.1. Dollar Cost as a Function of Percentage of a Firms Load Curtailed 
the firm curtailed half its load. The cost incurred by a utility in compensating two firms with identical load shapes to each have $50 \%$ of their loads curtailed would be less than what would have to be paid to one of the firms to curtail its entire load. Thus it seems that agreements by firms to curtail a portion of their demand are more efficient than agreements that call for the interruption of a firm's entire load.

Industrial response to interruptible rates rely heavily on the aforementioned considerations. Firms that expect the yearly savings in electricity expenditures to exceed the occasional costs incurred during interruptions will probably consider entry into interruptible agreements.

There exists a possible link between onsite generation and willingness to participate in interruptible rates. Onsite generation equipment may enable firms with rigid electricity needs to sustain interruption of power without incurring high costs.

\subsubsection{Case Studies Analyzed}

For analysis of reduced level of electricity use in response to electricity supply constraints, the most complete source surveyed was a document prepared by Pacific Gas and Electric Company (PG\&E) entitled The A-23(SC10) and AS-23(SC6) Curtailable Rate Options 1983 Analys is Report (Peles 1984). This document examines the performance of thirteen of PG\&E's largest commercial and industrial customers. The thirteen participants agreed to cut their electrical demand upon request to a customer designated Fim Service Level (FSL). This level was set at least $500 \mathrm{~kW}$ lower than their maximum peak demand for the previous year. Of the thirteen customers, nine were industrial firms. Table 4.6 displays a list of the industrial customers along with their SIC codes, peak demand and FSL. For our analysis we will look only at the industrial sector cross section of their commercial and industrial customers. Assuming this is correct, conclusions can be correctly drawn about the behavior of other customers within PG\&E's service area.

Two slightly different curtailment options were offered, Option $A$ and Option B. Table 4.7 outlines the main structures of the two options. 
TABLE 4.5. Customer End Use and Load Summary

\begin{tabular}{|c|c|c|c|c|}
\hline Customer & SIC & $\begin{array}{l}\text { Demand Max } \\
\text { Activity }\end{array}$ & $\mathrm{KW}$ Level & FSL \\
\hline A & 4456 & Chemicals & 3,599 & $4,500^{(a)}$ \\
\hline$c$ & 5000 & Glass Manufacturing & 4,581 & $5,000(a)$ \\
\hline $\mathrm{E}$ & 3241 & Hydrolic Cement & 28,780 & 20,500 \\
\hline $\mathrm{F}$ & 3241 & Sand Mine Processing & 715 & $6,400^{(a)}$ \\
\hline G & 2952 & Manufacturer & 11,342 & 6,000 \\
\hline$H$ & 3241 & Cement Processing & 10,640 & 6,000 \\
\hline J & 2873 & Ammonia Producer & 2,542 & $3,000^{(a)}$ \\
\hline k & 3312 & Stee 1 Production & 39,453 & 14,000 \\
\hline$L$ & 5004 & Steel Production & 4,340 & 1,000 \\
\hline
\end{tabular}

(a) FSL does not reflect actual demands. PG\&E changed the FSL. Source: PG\&E.

TABLE 4.7. Curtailment Rate Options

$\begin{array}{lccc}\text { Maximum Number of Curtailments/Year } & \text { Option A } & & \text { Option 8 } \\ \text { Maximum Curtai lment length, hours } & 10 & & 15 \\ \text { Maximum Notice Requirements, hours } & 6 & & 6 \\ \text { Performance Incentive, per kW curtailed } & \$ 4.40 & \$ 2.90\end{array}$

Source: PG\&E.

\subsubsection{Incent ives}

Under Schedule A-23, customers participating in the experimental program were credited each month with two dollars for every $\mathrm{kW}$ their peak demand exceeded their FSL. This credit was intended as an incentive to ensure that all of the electric demand would be curtailed when requested by PG\&E. In addition, the customers were to receive $\$ 4.40$ or $\$ 2.90$ for each $\mathrm{kW}$ per curtailment under Options $A$ and $B$ respectively. 
In order to ensure compliance, a penalty structure was imposed. A charge of five times the on-peak $\mathrm{kW}$ demand charge was assessed for every $\mathrm{kW}$ a customer's peak demand during a curtailment period was above their FSL.

Through participating in the program, customers lessened the likelihood of involuntary power disruptions since they would probably be called upon to curtail during periods when outages were eminent. This lowered their expected level of costs due to power disruptions. These costs tend to be lower when advance warning is received by the customer before power interruptions (Devine and Boyd 1981).

\subsubsection{Reductions in Demand}

Over the course of the 1983 summer season, ten curtailments of service under Option A and eight under Option B occurred reflecting capacity constraints experienced by the utility. Average peak demand reductions totaling $19,559 \mathrm{~kW}$ among the nine industrial firms for each curtailment were realized by PG\&E. This takes into account that not all customers participated in each curtailment period. Table 4.8 lists the estimated average impact of each of the

TABLE 4.8. Customer Demand Impacts ( $K W$ )

\begin{tabular}{|c|c|c|c|c|}
\hline Customer & $\begin{array}{l}\text { Estimated } \\
\text { Demand } \\
\text { Impacts } \\
\end{array}$ & $\begin{array}{c}\text { Est imated } \\
\text { Nommal } \\
\text { Demand } \\
\end{array}$ & $\begin{array}{l}\text { Percent } \\
\text { Demand } \\
\text { Reduction } \\
\end{array}$ & $\begin{array}{l}\text { Percent of } \\
\text { Time Compiled } \\
\text { with Requests } \\
\text { to Curtail }\end{array}$ \\
\hline A & $\rightarrow$ & -- & - & 0 \\
\hline$c$ & -- & $\ldots$ & - & 0 \\
\hline$E$ & 4,377 & 17,452 & 25.1 & 100 \\
\hline$F$ & - & -- & - & 0 \\
\hline G & 4,214 & 9,567 & 44.4 & 100 \\
\hline H & 1,786 & 7,037 & 25.4 & 100 \\
\hline $\mathrm{J}$ & 161 & 983 & 16.4 & 100 \\
\hline$k$ & 12,396 & 24,579 & 50.4 & 80 \\
\hline L & 3,341 & 3,966 & 84.2 & 100 \\
\hline
\end{tabular}

Source: PGRE. 
industrial firms in reducing peak demand. This was the mean difference between the actual demand during curtailment and what was estimated to be the load under normat circumstances. Three of the nine participants were never called upon because they were not above their FSL during curtailment periods.

Average demand reductions per customer ranged from 161 to $12,396 \mathrm{~kW}$. Expressed as a percentage, loads were reduced 16.4 to $84.2 \%$. With the exception of the three customers who were never above their FSL, the rate of compliance with requests to curtail was close to $100 \%$. This indicates that the customers involved offered a highly reliable source of emergency demand shedding capability. It would seem that sizable curtailments of demand are an economically feasihle response for industrial firms to peak supply constraints.

\subsubsection{Potential for Demand Reduction}

In this section we will estimate the demand reduction potential among those SIC's represented in the PG\&E study. For our estimates we will assume that all firms within a four digit SIC code in the U.S. enter into curtailment agreements. Table 4.9 outlines the total U.S. $1981 \mathrm{kWh}$ consumption of industries represented in the PG\&E study, as well as the percent demand reductions attained by the participating fims. In order to be conservative, we have assumed that all firms within these industries curtail their demand by hat $f$ the percentage demand reductions attained by the firms studied. Given a national industrial sector load factor of 0.75 , this reduction in peak demand would equal slightly more than $2 \mathrm{GW}$. This should serve as a conservative estimate of the reduction to industriat sector peak demand under curtailment agreements since it takes into account the response of only four industries at the four digit SIC level.

Estimates for reductions in peak demand for the entire industrial sector can be made given certain assumptions. The firms in the PG\&E study reduced their peak demand by an average of $26.4 \%$. Among the entire industrial sector there are probably many firms that could not reasonably be compensated to reduce any of their peak demand. Therefore, in order to be conservative, we will assume that $20 \%$ of the U.S. industrial sector participates in interruptible rates. Using these assumptions would result in peak demand reductions by 
TABLE 4.9. Potential Demand Reductions Among SIC's Represented in PG\&E Study

\begin{tabular}{|c|c|c|c|}
\hline SIC & Industry & $\begin{array}{l}\text { Customers } \\
\text { Represent ing } \\
\text { Industry } \\
\end{array}$ & $\begin{array}{l}\% \text { Reduction of } \\
\text { Demand Curtailed } \\
\text { in PG\&E Study }\end{array}$ \\
\hline 3873 & Ammonia & J & 16.4 \\
\hline 2952 & Asphalt & G & 14.4 \\
\hline 3241 & Cement, Hydrolic & $E, H$ & 25.4 (average) \\
\hline 3312 & $\begin{array}{l}\text { Blast furnaces, } \\
\text { steel work on } \\
\text { rolling mills }\end{array}$ & k & 50.4 \\
\hline
\end{tabular}

\begin{tabular}{|c|c|c|c|}
\hline SIC & $\begin{array}{c}1981 \text { Electric } \\
\text { Demand } \\
\text { (million kwh) }\end{array}$ & $\begin{array}{l}\text { Peak Demand } \\
\text { (load factor } \\
\text { of } 0.75 \text { ) } \\
\end{array}$ & $\begin{array}{l}\text { Reduction in Total } \\
\text { Demand Assuming Half } \\
\text { the Percentage } \\
\text { Reduct ion Realized } \\
\text { by firms in PG\&E Study }\end{array}$ \\
\hline 3873 & $4,374.5$ & $.67 \mathrm{GW}$ & $.05 \mathrm{GW}$ \\
\hline 9252 & 616.6 & .09 & .01 \\
\hline 3241 & $B, 923.2$ & 1.36 & .17 \\
\hline \multirow[t]{2}{*}{3312} & $49,377.8$ & 7.52 & 1.90 \\
\hline & & & Total: $2.13 \mathrm{GW}$ \\
\hline
\end{tabular}

Source: PG\&E and U.S. Bureau of the Census.

the industrial sector under interruption agreements of 5.92 gigawatts (or 5.2\%) off previously calculated 1983 levels. Applying the same methodology to industrial peak demand for 1990 and 1995 using the ORIM model would equal 7.8 GW and 9.4 GW, respectively. Using ISTUM 2 generated figures, the peak reduction for 1990 would equal $7.2 \mathrm{GW}$ and for 1995 would equal $8.5 \mathrm{GW}$.

\subsection{SHIFTING THE TIMING OF ELECTRICITY USE IN RESPONSE TO ELECTRICITY SUPPLY CONSTRAINTS}

Given proper incentives, industrial sector firms can respond to peak electricity supply constraints through shifting the timing of their activity and 
electricity consumption. Normally a certain component of a firm's demand coincides with utility peak period demand. If motivated, firms can sometimes shift the timing of a particular activity or process to off-peak periods and shift some of their peak electric demand.

Studies of industrial electricity use have shown that the demand for electricity by U.S. industry is affected by the price for electricity. Because of this price sensitivity, a prime vehicle for providing incentives for the industrial sector to shift the timing of their electricity consumption is with the time-of-use (TOU) rate structures.

TOU pricing is a mechanism for varying the price of electricity between times of the day and week when there is high demand for electricity (peak periods), and times when there is low demand (off-peak periods). Generally, two components of utility rates, the demand charge and the energy charge are varied in order to provide an incentive for customers to shift as much of their electricity demand as possible away from peak periods to coincide with utility offpeak periods. In many cases, the demand change, the price per kw level, applies only to peak periods. The energy charge, the price per $k$ wh consumed, is generally set at a higher rate for peak periods than for off-peak periods.

TOU rates offer distinct advantages over non-TOU rate structures both to utilities and society at large. TOU rates offer a mechanism to promote the efficient use of resources. Through electricity rates, utilities send out "signals" informing end users of the comparative scarcity of the supply of generated power relative to demand for a given time period. If the difference in the price of electricity between peak and off peak hours is great enough, individual end-users will tend to respond by shifting part of their load away from the more expensive peak periods where possible. This promotes efficiency within the electricity sector which ultimately benefits the econony as a whole.

The actual level of response by industry to TOU rates is dependent on many factors. Of primary importance, is the consideration of technical feasibility. For many industrial applications, there are tremendous barriers to shifting demand. Firms that engage in continuous ratier than batch production often have a low potential for shifting load. A firm that processes continuously such as an aluminum or ammonia producer, runs an unending process keeping their 
equipment going nonstop. Since there is no actual time between when one amount of material is finished and before another is started, there is little opportunity for shifting part of the processing to off-peak periods. A firm that produces in batches such as a shoe or furniture manufacturer can often shift the timing of a certain process to off-peak periods assuming that not all of the plant's capacity is being used around the clock.

Many of the industries that are the largest consumers of electric power typically run plants at full capacity 24 hours a day, 365 days a year in order to make the best use of expensive machinery and equipment. In these industries there is very little potential for shifting demand away from peaks without suffering production losses, except by investing in additional equipment.

After the issue of technical feasibility are questions of economic feasibility. These include the specific terms of the Tou rates (in particular the on-peak to off-peak prices), the cost of any capital equipment necessary to enable demand shifting, the relative cost of other types of energy, any differentials incurred due to higher maintenance and operating costs and, any increases in the price of labor due to overtime in off-peak hours to make up for losses in production.

There exists a close link between the potential for demand shifting and the availability of cost effective onsite self-generation and co-generation. The acquisition of self-generation can enable firms to limit the purchase of power during expensive peak periods without actually limiting or changing the firm's electrical usage. TOU rate structures have already given rise to increased use of self-generation and co-generation in Europe (Mitchell et a?. $1977)$.

\subsubsection{Case Studies Analyzed}

In order to analyze the nature of the responsiveness of the industrial sector to shifting electrical demand to accommodate on-peak electricity supply constraints under TOU pricing, a brief survey of available literature was undertaken. Several of the best sources of data were selected for in-depth analysis. 
Industria? Response to Time of Day Pricing (EPRI 1980) provides technical and economic assessments of the potential costs and benefits of actual firms' responses to TOU rate structures. Southern California Edison's experience with TOU rates also provides an analysis of industrial response to TOU rates. Finally, Peak-load Pricing: European Lessons For U.S. Energy Policy (Mitchell et a1. 1977) provides some insight into European industriai response to TOU rates as well as an estimate of potential load reductions to the U.S. industrial sector based on TOU rate experience in France and California.

\subsubsection{Incentives for Shifting the Timing of Electrical Use}

Under TOU rates, the main incentive to shift the timing of activity away from peak periods is to save money on electricity bills. These savings are a direct function of the differential in demand and energy charges between peak and off-peak periods. Firms may also respond for reliability reasons. Since most complete or partial power outages occur during system peaks, firms can lessen the chance of their activity being curtailed by unplanned outages by shifting their activity to off-peak periods (Meyers et al. 1976).

\subsubsection{Technical Feasibility of Shifting the Timing of Industrial Activity}

Economic theory suggests that firms will shift their electric demand from peak periods to off peak periods under ToU pricing to the point where the cost in shifting the demand equals the benefit derived from reductions in electricity expenditure reflecting the cifferential cost between peak and off-peak rates. This assumes that decision makers have complete knowledge and awareness about the specific costs of peak and off peak power as well as the exact amount of electricity employed by certain processes and the cost of moving those processes from peak to off peak periods.

In Industrial Response to Time of Day Pricing (EPRI, 1980) seventeen technically feasible strategies for shifting electric demand to off-peak periods were evaluated for seven industries. An assumption was made that Tou rates were available to all firms studied. Each of the strategies was then evaluated for economic feasibility, with calculations for the rates at which they would be cost effective. Five of these strategies among tive industries were deemed economically feasible: 
- addition of cogeneration equipment in a steel refinery for maximizing power generation during peak hours,

- addition of steel rod production capacity for shifting production to off-peak hours in steel mini-mills,

- shifting "clinker grinding" to off-peak hours during the winter slack season for cement production,

- storage of waste liquors for use in cogeneration during peak hours in the paper industry, and

- addition to storage capacity to allow scheduling off-peak petroleum pumping.

A representative case is that of the steel rod producing electric minimill. In this case, the addition of new production capacity is necessary to enable significant shifts of electric demand away from peak periods. The installation of two arc furnaces allows a shift in the mill's entire 928 tons/day production of raw steel off-peak. The on-peak demand is reduced by $31 \mathrm{MW}$ (38\% of total on-peak load before reduction).

The cost of the equipment additions outlined would be about $\$ 25$ million. According to the study, this represents a levelized cost of $\$ 3.98$ million a year. The mi11 examined, is served by West Penn Power Company. The displaced demand charge (peak hour only) is $\$ 2.43$ a $\mathrm{kW}$ which should translate to an annuat savings of $\$ .92$ million. In order for the project to be viable the savings in energy changes must be greater than $\$ 3.06$ million a year. Given this fact, the energy charges making this project economical can be figured using the equation:

$$
109.5 y-186.15 x=3,060
$$

where $x$ and $y$ represent off-peak and peak energy charges respectively in mills $(1 / 10$ of a cent). The constants equal the number of $k$ wh's under each rate per year. If the ratio of peak to off-peak charges is arbitrarily set at $4: 1$, the rates would be 12 and $48 \mathrm{mills} / \mathrm{kWh}$ respectively. For other ratios of peak to off-peak rates, the actual rates woutd differ. 
The project was found to be uneconomical under the company's present rate structure yet was found to be economical for rate structures of other utilities.

This example underlines the point that economical load shifting by a firm is contingent on a number of variables. Load shifting under Tou can be costeffective for a firm, but each particular case must be evaluated before this can be assessed.

\subsubsection{Demonstrated Peak Demand Reductions Under TOU Rates}

In order to assess actual reductions in demand under ToU rates within a particular utility service area, we have examined a number of TOU studies prepared by Southern California Edison Company (SCE).

In 1977, the California Public Utility Commission ordered the establishment of mandatory TOU rates by all utilities within the state for customers with demands greater than $5000 \mathrm{~kW}$. Approximately 120 Southern California Edison customers are currently within this group. of those, 97 have been on Tou rates from the time of their installation and can provide baseline data for comparison from the year November 1976 through October 1977.

In Analysis of Impacts of Time-of-Use Rates for Large Commercial and Industrial Customers (1984) data on consumption and average monthly demand indicated that the over $5000 \mathrm{~kW}$ demand group has decreased its annual on-peak electric consumption $3.29 \%$ relative to 1977 levels. The adjusted peak demand (multiplied by the ratio of base year electric consumption to that of each year) has generally dropped, while maximum diversified demand (that of mid-or off peak periods) has increased. This implies a relative decline in peak compared to off peak demand. Total reductions in the average on-peak $\mathrm{kW}$ demand for the over $5000 \mathrm{~kW}$ group were estimated at $44.256 \mathrm{~kW}$ for summer and $60.141 \mathrm{~kW}$ for winter. This is quite low in relation to the group's average peak demand of 10,500 and $11,000 \mathrm{~kW}$, equal to between $\mathrm{a} .5 \%$ and $1 \%$ reduction.

For the 120 customers in the over $5000 \mathrm{~kW}$ group, the total reduction in on-peak demand averaged 5.5 - 7.3 MW for the 1983 season over 1977 levels. This is a relatively small piece of the utility's total capacity of 13,593 MW. 
There is a 2.15:1 ratio between peak and off-peak energy prices for the SCE examples. This explains in part the low responsiveness of peak demand to TOU rates. Econometric analysis of commercial and industrial response for the over $5000 \mathrm{~kW}$ group to TOU rates indicates that the demand elasticities are in the range of -0.1 to -0.01 showing a significant insensitivity of Tou energy demand to price changes (Hirschberg and Aigner 1982).

These measures of elasticity are valid only for rates that are within the same general price range as found at SCE $(1.2564 / \mathrm{kWh}$ on-peak; $0.583 \$ / \mathrm{kWh}$ offpeak). It is possible that with much higher differentials between peak and off peak energy rates, industrial firms might respond differently and shift much larger portions of their load in relation to the changes in price. Given the experience in California, these increased rate differentials would be impractical to implement because of the hardship placed upon firms within this customer class that cannot shift their load under any circumstances.

\subsubsection{Potential Peak Demand Reduction}

In Peak Load Pricing: European Lessons for U.S. Energy Policy, (Mitchell et al. 1976) an estimate of on-peak reductions due to nationwide implementation to Tou pricing was developed. The analysis is based on the French experience with TOU pricing. Using four separate methodologies, varying assumptions as to whether U.J. reductions in on-peak consumption will be proportional to French data or if U.S. industries will actually take on the load shapes of French industries, reductions in peak demand for the entire U.S. industrial sector have been estimated at 11.7 to 28.4 gigawatts. A timeframe for these estimates was not provided in the study.

Reductions in $\mathrm{kW}$ demand for 17 U.S. industries at the 2 to 4 digit SIC level with direct counterparts within the French economy were estimated. It has been assumed that these industries, which consume about $60 \%$ of U.S. total industrial electricity, will shift their loads to the point where they mirror French behavior. The Mitchell analysis used load curves from Pacific Gas and Electric Company before and after the institution of TOU rates in California in 1977. Recent information indicates that the shift in peak period demand by customers cited in this study was highly atypical. 
For the French, the differential between peak and off-peak rates was 6.6:1. This is much larger than differentials in utility rates presently available in the U.S. It is highly doubtful that rate differentials of this size could be enacted without causing substantial harm to the many customers that could not effectively shift their electric use away from peak periods.

The findings of this study, that large blocks of U.S. industrial peak demand ( 11.7 to 28.4 GW) will be shifted easily upon the adaptation of TOU rates are not consistent with the findings of SCE. In general, U.S. industry has not responded by shifting peak demand by great margins. The data suggests that it is not always cost effective for industrial firms to shift demand toward off-peak periods and that when they do, it is in small amounts. The analys is of EPRI indicates that while large shifts may be technically feasible, actual decisions are based on a matrix of complex variables, making large scale changes in the timing of demand very sensitive to economic factors. Key among these factors is the differential in peak to off-peak rates.

Applying the results of the SCE study $(0.5$ to $1 \%$ reductions in industrial peak demand) to EIA data on overall industrial sector demand would equal a reduction of 0.59 to 1.18 GW off of 1983 peak levels assuming a load factor of 0.75 . Using the estimated peak electric demand projection based on the ORIM and ISTUM-2 models, this would yield a reduction of 0.72 to $1.56 \mathrm{GW}$ for 1990 and a reduction of 0.85 to $1.87 \mathrm{GW}$ for 1995.

\subsubsection{Conclusion}

Peak demand by the industrial sector can be reduced by providing special TOU rates as monetary incentives to shift the timing of activities. However, it appears that this potential is not neariy as great as the 11.7 to $28 \mathrm{GW}$ cited by Mitchell. Also, what is technically feasible may not make business sense unless monetary incentives differ substantially from what has been offered. Reductions in peak demand cannot reasonably be expected to be much larger than the 0.5 to $1 \%$ cited by SCE unless on-peak to off-peak price differentials increase from $2: 1$ to $7: 1$. 


\subsection{ADOPTION OF SELF GENERATION IN RESPONSE TO ELECTRICITY SUJPPLY CONSTRAINTS}

A significant area of potential response by the industrial sector is the increased installation of onsite generation capacity. Over the past several decades, industrial sector firms have relied increasingly on electric utilities for their power supply. In 1982, industrial firms generated only $7.4 \%$ of their total electricity consumption (Bureau of the Census 1983). This compares with $19 \%$ in 1960 and $36 \%$ in 1939 (EPRI 1981). This trend represents the long-term decrease in the price of purchased electricity relative to the costs of onsite generation.

Recent use of onsite generation has been concentrated in industries where a cheap source of generator fuel is available. For example, almost $70 \%$ of the generated kilowatt hours in 1981 were generated by paper and primary chemical industry mainly using waste fuels (Bureau of Census 1982; OTA 1983).

Given electricity supply constraints, a large potential market exists for onsite generating capacity for use during power disruptions. On the other hand, the use of onsite generation equipment as a source of baseload power is generaliy not cost effective due to the high price of purchased fuels. In most cases, electricity can be supplied by utilities at a lower kWh cost.

\subsubsection{Cases Analyzed}

Due to the highly proprietary nature of information needed, many firms that had installed onsite generation systems were unwilling to discuss the specifics of the costs, benefits and associated considerations that contributed to their decision to install. Subsequently, we relied primarily on documented cases for our information. One firm was very cooperative and agreed to help with the study, but insisted that they remain anonynous.

In Costs of Electric Outages to Manufacturers Oevine and Boyd (1981) estimated both the fixed and variable costs of installing onsite generating capacity. Table 4.10 outlines the results of their market research on the cost of generating systems. They have identified the annual investment cost as a function of : 
TABLE 4.10. Capital and Operating Costs of Standby Electricity Generating Systems, mid-1980

\begin{tabular}{|c|c|c|c|c|}
\hline $\begin{array}{l}\text { Capacity } \\
\text { Range (MW) } \\
\end{array}$ & Prime Mover & $\begin{array}{c}\text { Approximate } \\
\text { Installed } \\
\text { Cost }(\$ / \mathrm{kw})(\mathrm{a}) \\
\end{array}$ & $\begin{array}{l}\text { Fuel } \\
\text { Consumpt i on } \\
\text { (Btu/kwh) } \\
\end{array}$ & $\begin{array}{c}\text { Maintenance } \\
\text { Cost } \\
(\$ / y r)(c) \\
\end{array}$ \\
\hline $0.1-1.0$ & Diesel engine & 350 & $8,400-11,100$ & $300-3,000$ \\
\hline $1-3$ & Gas turbine & 360 & $12,100-16,600$ & 750 \\
\hline $3-20$ & Gas turbine & $243-270$ & $11,400-12,100$ & $750-1,500$ \\
\hline $20-60$ & Gas turbine & 133 & $11,400-11,500$ & $2,500-5,000$ \\
\hline$>60$ & Gas turbine & 116 & $11,400-11,500$ & $2,500-5,000$ \\
\hline
\end{tabular}

Source: Divine and Boyd 1981, p. 37.

(a) Gas turbines are assumed to operate at $80^{\circ} \mathrm{F}$ ambient temperature and at elevations less than 1,000 feet above sea level. Costs include an increment to cover switchgear for parallel operation of individual sets, as appropriate.

(b) Engines and turbines are assumed to operate on diesel fuel with a lower heating value of $143,520 \mathrm{Btu} / \mathrm{gall}$ on.

(c) Includes labor at $\$ 15$ per hour plus an increment for parts, and assumes that the user follows recommended schedules for preventive maintenance and system exercising.

- the initial installed price,

- the after tax cost of money,

- the income tax rate,

- the levelized depreciation rate, and

- the ad valorem tax rates.

Their analysis of the costs associated with installing a generation system is illustrated with a hypothetical example. The system outlined has a $35 \mathrm{MW}$ name-plate capacity. Capital costs have been estimated at $\$ 133 / \mathrm{kW}$ or $\$ 4,655,000$ total. With a $20 \%$ fixed capital charge rate, this would equal $\$ 931,000$ a year. Variable costs were estimated based on ten one-hour outages a year, but we have adjusted this to our assumed fifteen outages a year with a duration of six hours each. The cost of fuel for running the system 90 hours/year would be $\$ 253,800$ assuming a conversion rate of 11,500 BTU/kWh, a heating value of 143,520 BTU/galion, and a cost of $\$ 1.00 / g a l l o n$ for diesel fuel. Maintenance costs for a system this size have been cited as being 
$\$ 5,000$ year. Thus the total costs for providing $3,150,000 \mathrm{kWh}$ of electricity a year would come out to $\$ 1,189,800$ or $\$ 0.38 / \mathrm{kWh}$. Although this is much higher than the rates charged by utilities, this is quite low compared with the costs cited in several studies estimating the costs to industry due to outages (Sanghvi 1982, Billington 1982).

Many firms may suffer extensive damage to equipment during the first few minutes of a power outage due to sudden drops in voltage (Billington et al. 1982). Onsite generators that can be activated by the utility in the case of a service interruption can solve this problem. Such a system could enable additional firms to participate in interruptible power agreements where ordinarily they might be too sensitive to disruptions in power to consider this option.

A firm in LaGrange, Illinois, Energy Systems Engineers (ESE) is currently involved in the design and installation of utility triggered onsite generation systems. The general cost of these diesel systems that come as large as $10 \mathrm{MW}$ is about $\$ 280$ per $\mathrm{KW}$ installed. Cost effectiveness is based on savings due to expected outage costs and incentives received from participation in interruption agreements.

A firm in Illinois producing iron and steel forgings (SIC 3462) recently purchased such a system from ESE. Because of capacity constraints due to excess demand during the particularly hot summer of 1982, Commonwealth Edison interrupted power nineteen times. The firm investigated the option of installing an onsite generation system as a way of cutting losses due to down time and to take advantage of an interruption agreement available. When operations are shut down during power interruptions, there is very little opportunity for making up production, since the plant operates at full capacity virtually all the time. Principal components of costs due to outages are cited by a company officer as being loss of production, damage to equipment and material stock, and loss of efficiency.

The system installed has a name-plate capacity of $8400 \mathrm{~kW}$ which is capable of meeting the plant's entire peak monthly demand. The total installed cost of the system was approximately $\$ 2.3$ million. Under their existent utility rate structure the company comptroller cited annual savings of about $\$ 500,000$. He 
also noted that the tax benefits through depreciation and investment tax credits made this a very attractive venture. The main justification for the system was reported as the "pure economics" of the system. Other possible benefits cited included use as a backup generator and as a marketing tool promoting their ability to deliver orders despite power outages.

Under their interruption agreement, Commonwealth Edison is allowed to interrupt thirty times a year for up to twelve hours. Ten minutes before interruption the forging company is notified. From the firm's standpoint, the backup generator should be triggered by the utility so as to avoid discontinuity in voltage. Due to a minor problem, the system in Illinois has not completely solved the voltage reduction problem. The forge company must manually shut down upon notification by the utility and immediately start the generator. A conversation with the company comptrolier indicated that this problem will probably be solved in the very near future.

Systems like this seem highly adaptable. A considerable constraint, though, is the availability of interruption options for cases where they are necessary to justify the cost of the system. In the case of Commonwealth Edison, there is presently a moratorium on future interruption agreements as the utility has sufficient interruptible capability. If electricity supply constraints become severe enough, there may be increased interest in the installation of systems like this to take advantage of the greater availability of interruption agreements. Other Iimitations on the installation of onsite generation equipment include uncertainty about future fuel costs, environmental regulation and the need for trained personnel to run and maintain the systems.

\subsubsection{Cogeneration}

Cogeneration is the dual production of electric power and thermal energy (steam or heat) for an industrial process. Its attractiveness lies in the increased efficiency of producing both at once. Large scale interest in cogeneration in recent years is due to legislation under the Public Utility Regulatory Policies Act of 1978 (PURPA). Because cogeneration often generates more electricity than needed in proportion to the amount of steam produced, there 
exists ample opportunity to sell the electricity. Under PURPA, utilities are required to pay the "avoided cost" (the amount it would cost to produce that additional amount of electricity) to qualified facilities.

An analysis of cogeneration as a method of producing electricity for sale to a utility is beyond the scope of this work. However, because of the recent interest in cogeneration, there exists a substantial literature on the market potential.

In Industrial Response to Time-of-Day Pricing (EPRI October 1980), the application of a cogeneration system for use in a petroleum refinery is discussed. The economic feasibility of the system is evaluated based on the potential for displacement of peak period electricity purchases under TOU rates.

The cogeneration system outlined for the $150,000 \mathrm{bbl} /$ day petroleum refinery displaced the entire peak load of $50 \mathrm{MW}$ as well as supplying a considerable amount of steam. The system was designed to operate only during peak hours at an installed price of $\$ 16.5 \mathrm{million}$ or $\$ 330 / \mathrm{kW}$.

The main operating expenses are listed and broken down in the EPRI report as displayed in Table 4.11 .

Total annual cost would run $\$ 7$ million. Benefits from steam production would equal about $\$ 6.25$ million. Therefore, the economic feasibility of the project is dependent on the avoided demand charge plus the number of $k$ Wh at peak rates displaced. If the total of the avoided demand charge and peak energy rates is greater than $\$ 6.45$ million a year (the $\$ 12.7$ million annual costs minus the $\$ 6.25$ benefit in steam production), the system would be cost effective. Assuming this system displaces $50 \mathrm{MW}$ of electric demand for 60 hours a week, the differential in peak to off-peak electricity prices would have to be $\$ .04 / \mathrm{kWh}$. This cost-benefit analysis is based solely on avoidance of peak utility rates. If allowance is made for avoidance of possible power disruptions, which are most likely to occur during utility peak periods, the benefits would be considerabiy greater than just the avoided peak utility rates. 
TABLE 4.11. Operating Expenses of Sample Cogeneration System

Capital Carrying Change

$\$ 2.6$ million

Fuel

$630,000 \mathrm{lb} / \mathrm{hr}$ steam at $1500 \mathrm{psig}$ and $950^{\circ} \mathrm{F}=630,000 \times 1290 \mathrm{Btu} / \mathrm{hr}$

$=1,779$ billion Btu/year

( 0.25 operating factor)

Manpower

1 day supervisor $\quad=50,000$

1 electrical engineer $=25,000$

5 operators $(5 \times 20,000) \quad=80,000$

Benefits at $30 \%$ of labor costs $=46,500$

Totat

$=\$ 201,500$

Maintenance

$4 \%$ of investment $\quad=\$ 660,000$

Other costs (insurance, chemicals, etc.)

$2 \%$ of investment $\quad=\$ 330,000$

Source: EPRI 1980

\subsubsection{Potential for Peak Demand Reduction}

Unlike most of the other response options available to the industrial sector the adoption of onsite generating equipment involves the physical purchase of equipment. As such the potential for increased onsite generation and cogeneration is affected by the availability of capital and the favorability of tax laws as well as the factors discussed for the other responses.

In Forecasting Inplant Electricity Generation in the Industrial Sector 1980-2000 (EPRI 1981) a projection has been made that should serve as a low-end estimate. The forecast for inplant generation, including cogeneration, is based on a "best guess" set of assumptions. It calls for a rise in self generation to about 100 billion $k$ Wh by 1990 followed by a gradual decline during the 
1990 's. This figure is approximately twice the 1981 level for inplant generation. Assuming a load factor of 0.75 , the increase would equal 8.37 GW over 1983 levels.

As reported by Davidson and Hedman (1984) of the Gas Research Institute (GRI), a recent study conducted for the Department of Energy estimated the potential for steam electric cogeneration at the 10,000 largest manufacturing sites in the U.S. Based on a profile of industry in 1980, $43 \mathrm{GW}$ of retrofit cogeneration capacity would be possible given a return on investment of $7 \%$. The study also estimated that there could be an extra 48.5 MW of cogeneration capacity by the year 2000 based on Department of Commerce growth projections and assuming similar characteristics of new plants to old plants.

Of the $43 \mathrm{GW}$ of cogeneration potential, over $90 \%$ is located in five industries: Food (SIC 20), Paper (SIC 26), Chemicals (SIC 28), Petroleum (SIC 29) and Primary Metals (SIC 34). The high representation of the paper, petroleum and chemical industries is in part due to the availability of waste products for use as cheap sources of fuel (OTA, 1982).

These estimates of potential represent the amount of technically and economically feasible applications and do not represent what is expected to develop over the 1985 to 1995 timeframe. Under three different scenarios, GRI has projected industrial cogeneration development at $7.5 \mathrm{GW}$ to $27 \mathrm{GW}$ of system sales over the 1982-1995 timeframe. Factors that will influence the actual amount of generation capacity include uncertainty about the effects of pertinent Tegislation such as PURPA, air quality standards, the relative prices of electricity and other fuels, changes in available technologies, the availability of financing and the general shape of the economy (Davidson and Hedman 1984). Because of substantial uncertainty regarding the levels of these factors and the degree of effect they will have on the amount of cogeneration, it is nearly impossible to estimate the levels of increased cogeneration activity within the industrial sector expected for 1990-1995 with a high degree of confidence. The mid-level GRI scenario probably gives the best projection however 
since it corresponds most closely with current economic and regulatory conditions. This scenario calls for 16 GW of cogeneration capacity by 1993. Most of this development would be in the paper, chemicals and petroleum refining industries with chemicals accounting for $55 \%$.

Potential for onsite generation could be less than for cogeneration. Ordinary onsite generation generally does not have the advantage that cogenera. tion offers in terms of increased efficiency. From a societal point of view, there is little difference between the installation of a generation system in an industrial setting and additions to utility peaking capacity. If economies of scale exist in the efficiencies of generators relative to size, the installation of generating equipment by industrial firms onsite is less advantageous than additions to utility peaking capacity. This advantage could be negated by energy losses inherent with the transmission of electricity. From a firm's point of view, the addition of onsite generation may have several advantages over utility additions. First, the firm may assure itself that the generated electricity from the added capacity is made available to them when needed. Secondly, the firm lessens their exposure to random power outages due to system failure since they have purchased back-up supply.

Onsite generation does offer an advantage of being a response that can be adopted by firms without necessarily involving significant changes in their behavior. Generation systems that do not involve neat production may be well suited for situations where large quantities of hot water or steam are not required or where there is insufficient capital available to finance the costs of cogeneration.

Estimates for potential onsite generation and cogeneration can be derived by assuming that the industrial sector will return to historical levels of generating their own power needs. If industry generates the same percentage of power in 1990 as they did in 1960 (19\%) and the same percentage in 1995 as in 1955 (22\%) this would equal reductions of 17.12 caW and 26.26 GW given the estimate derived with ORIM data and 15.84 GW and 23.75 GW using ISTUM-2 data. 


\subsection{PURCHASE OF ENERGY EFFICIENT TECHNOLOGIES AS A RESPONSE TO ELECTRICITY SUPPLY CONSTRAINTS}

Although they do not represent actual responses to electricity supply constraints, a variety of higher efficiency technologies exist that could have impact on the level of industrial sector peak demand. Through replacing an old technology with a new more energy efficient technology, energy savings will occur during times that a process uses the technology. The general effect of the adoption of high efficiency technologies by a plant will be a general lowering of the plants electricity demand for the hours that the technology is used. Figure 4.2 demonstrates this graphically, assuming that the replacement higher efficiency technology runs all day.

If an efficient technology is widely adopted, the aggregate effect of a lowering in demand during utility peak periods could cut the likelihood of the peak supply constraints due to excess demand.

\subsubsection{Technologies Examined}

A wide array of energy efficient technologies have the potential to affect industrial sector peak demand. These include energy management systems, new electrolytic processes, high efficiency motors and adjustable speed motor drives. High efficiency motors could significantly decrease industrial sector electricity demand, because electric motors are the largest single component of industrial electric load. In 1980, electric motors accounted for approximately $53 \%$ of all electricity used by the industrial sector (EPRI 1980). Because of the heterogeneity of the industrial sector, it is very difficult to assess the available potential for technologies such as energy management and specific electrolytic processes. A study of these would require disaggregated analysis on an industry by industry basis. Given this fact, we limited our analysis to peak energy savings due to the increased adoption of high efficiency motors and adjustable speed motor drives.

\subsubsection{High Efficiency Electric Motors (HEM)}

At present, electric motors are relatively efficient in terms of their mechanical power output for a given electrical input. Typically, this translates into efficiencies of 75 to $95 \%$. By making fairly simple changes in 


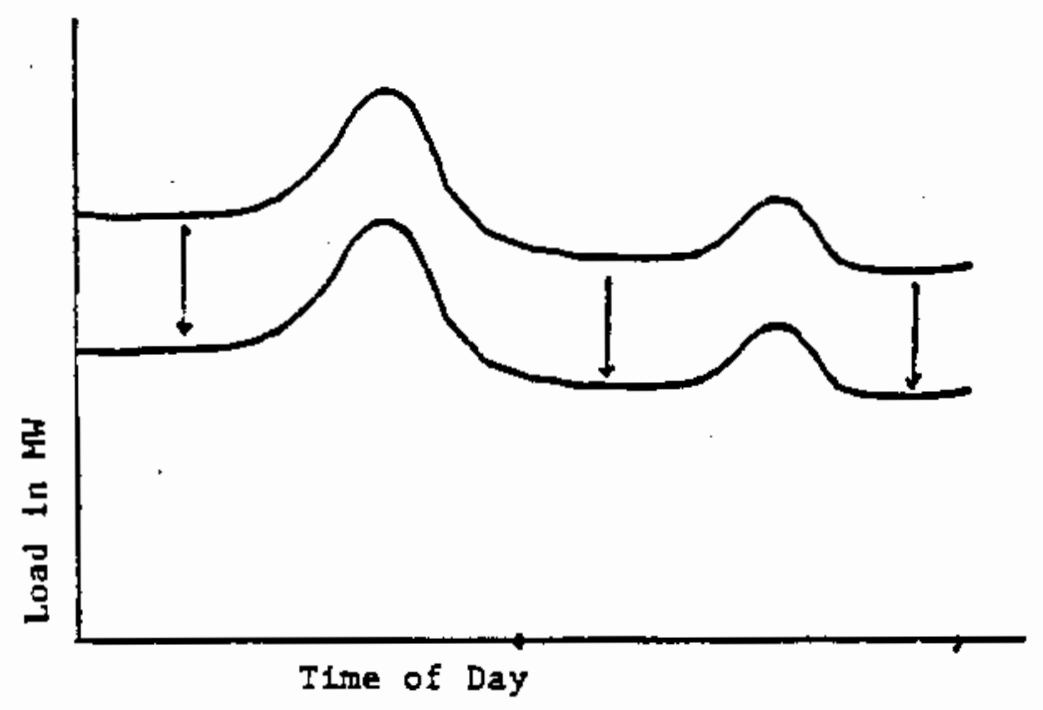

FIGURE 4.2. General Effect of Adopting High Efficiency Technologies

design and materials such as increased copper windings, longer motor and strator cores and lightweight silicon steel, efficiencies can be boosted 1 to $14 \%$ (Moe 1986).

HEMs operate in exactiy the same manner as standard motors and have the same lifetime. Because of the use of more expensive materials they tend to cost $30 \%$ more than standard motors (Moe 1986).

In industrial settings, electric motors often are run close to $100 \%$ of the time. In many cases the annual cost of electricity used by the motor exceeds its initial purchase price by five to ten times (Sheahan, 1983). Thus even sma1l increases in the nominal efficiency of HEMs may make them cost effective in comparison to standard electric motors. In some cases, electricity savings may even warrant the early replacement of a standard motor with a HEM.

Future energy savings due to adoption of HEMs will be defined by the market potential for new motor applications as well as the market for replacement and retrofit installations. Actual decisions on specific installations will depend on the cost effectiveness of the HEM over a-standard motor as determined by the specific situation. 
In a draft report for the U.S. DOE (Moe et al. 1986) the market potential for HEMs was estimated for the year 2000. The analysis is based on the costeffectiveness of five classes of differently sized HEMs. The cost effectiveness is based on expected yearly electric savings versus the incremental capital cost for HEMs over standard motors. An estimated payback period has been calculated for typical applications within each size classification. Certain size groups are characterized in the study as having much shorter payback periods than others. Based on these payback periods, future annual motor population growth rates and motor retirement rates, estimates of market penetration have been derived as well as expected motor populations.

Estimates of total energy savings due to the adoption of high efficiency motors were generated by subtracting the estimated electricity consumption of HEMs from the estimated electricity consumption of standard motors. This yields an estimate of annual electricity savings $1.61 \times 109 \mathrm{kth}$ for 1990 and $3.56 \times 109 \mathrm{kWh}$ for 1995. Dividing these figures by 8760 hours/year gives average energy reductions of 132.4 and $406.4 \mathrm{~kW}$ for 1990 and 1995. Since electric motors typically are used such a high percentage of the time, an average load factor of . 90 is probably reasonable. Dividing the average electric reductions by .90 gives an estimated peak load reduction of $197.1 \mathrm{MW}$ for 1990 and $451.5 \mathrm{MW}$ for 1995.

\subsubsection{Adjustable Speed Motor Drives}

Adjustable speed motor drives (ASDS) are devices that can regulate the speed of a motor in situations where motor power output requirements are not constant over time. In situations where a motor is kept at a constant speed at different times during a production process, significant amounts of electricity may be wasted. ASDs can reduce the level of waste by varying motor speed to match output requirements.

ASDs can regulate motor speed mechanically or electronically. Mechanical ASDs use hydraulic clutches while electronic ASDs control motor speed by changing the frequency of power input to the motor.

Benefit from using ASDs depends upon the situations where they are used. Benefits include electricity expenditure savings as well as reductions of wear 
and tear to motors. The actual advantage to be gained is a function of variation in output associated with the motor. In cases where motor output fluctuates widely between two different levels, a large benefit may be possible. In cases where little or no fluctuation is expected, then ASDs probably offer no benefit (Moe et al. 1986).

In general the cost effectiveness of ASDs is a function of their expected annual energy savings and their initial capital cost. In retrofit situations the initial capital cost will be augmented with additional costs for installation. Energy savings from installations will vary considerably according to the particular case. EPRI estimates that overall energy savings should be approximately 30 to 50\% (EPRI 1984).

Potential MW savings from ASDs will depend on the potential for new applications as well as the market for retrofit installations.

In a draft report to the U.S. DOE (Moe et al. 1986) the market potential for ASDs has been estimated for the year 2000. Their analysis is based on assessing the cost effectiveness of five classes of differently sized ASDs. Based on the number of years to payback, the original investment in each size of ASD was evaluated using expected annual kWh savings. Only ASDs for motors sized $50 \mathrm{hp}$ and above were found cost effective. Ising data on current and projected electric motor populations, growth rates and retirement rates for motors larger than $50 \mathrm{hp}$ were estimated and expected energy savings calculated as follows. The expected savings are $17.7 \times 109 \mathrm{kWh}$ for 1990 and $35.1 \times$ $109 \mathrm{kWh}$ for 1995. Dividing these by 8760 hours and an expected load factor of 0.90 yields industrial sector peak load reductions of $2.24 \mathrm{GW}$ and $4.45 \mathrm{GW}$ respectively for 1990 and 1995.

These reductions through the increased use of ASDs would be much Jarger than the expected reductions due to the adoption of HEMs. This is because the increase in efficiency available with ASDs is greater than the increase in efficiency available with high-efficiency motors. 


\subsection{RELOCATION IN RESPONSE TO ELECTRICITY SUPPLY CONSTRAINTS}

A possible response by the industrial sector to capacity constraints is to discontinue activity and relocate to areas free from supply problems. Our analysis indicates that capacity constraints are likely to be more prevalent in certain areas of the country reflecting changes in growth patterns and demographics over the next ten years. These areas include Florida, California and Texas.

If constraints become severe enough in their frequency and duration, firms and industries that are especialiy sensitive to power disruptions may consider relocating to areas with available or cheaper capacity. It is very unlikely that firms other than those most sensitive to fluctuations in electricity supply will relocate solely on the basis of capacity constraints. There may exist a larger body of firms that will regard capacity constraints as a contributing factor in their decision to relocate.

Relocation as a response to electricity supply constraints would probably constitute a measure of last resort. Firms would pursue this as an option only after all other avenues have been explored. Before relocation would occur, firms would most likely explore the technical and economic feasibility of first shifting the timing of their electricity using activities and second, installing self-generation or co-generation capacity. Firms that would make good candidates for relocation under supply constraints include those that use large amounts of electricity on a continuous basis, and cannot economically shift the timing of their usage or install onsite generation capacity. An example would be firms in the aluminum and chemical industries.

Capacity constraints may also limit the future migration of firms into areas affected. Firms may be reluctant to locate in areas perceived to have electricity supply problems. Included are both firms considering relocation to the region and firms establishing themselves for the first time.

\subsubsection{Literature Review}

Perhaps due to the recent history of an abundance of electric supply in the United States, we could find little documented evidence of industrial firms relocating in response to supply constraints. 
The one case that has been partly documented is that of firms in the primary aluminum industry leaving the Pacific Northwest region during 1973. In this year, the Pacific Northwest, which is highly reliant upon hydroelectric generation, suffered a drought. When firms were asked to voluntarily cut their power consumption, some aluminum producers laid off workers and transferred production to other parts of the country. This is partly due to the unique nature of the aluminum industry, which relies on upon a continuous supply of cheap electricity in order to make use of very expensive plants and machinery. 4.6.2 Interviews with Industry officials

Because of the lack of documented cases of fims relocating as a response to electricity supply constraints a series of interviews were conducted with senior officials from associations and organizations representing major electricity consuming industries to assess the likelihood and potential for this response. Officials were contacted from the National Petroleum Refiners Association, the Chemical Manufacturers Association, the Aluminum Association, the National Association of Manufacturers, the American Paper Institute, and the American Iron and Steel Institute. Each of these organizations has the most comprehensive membership among their respective industries. Collectively the industries they represent account for approximately $50 \%$ of the total electricity demand among the industrial sector (Bureau of Census, 1983).

Each of the representatives from the associations was informed of the scope of this effort and of our electricity supply constraint scenario. In the interviews, it became evident that all of the major industries evaluated are highly sensitive to supply disruptions especially those that might occur without warning. None of the industry spokespersons, including those that functioned as energy specialists, had devoted significant previous attention to issues concerning or related to our supply constraint scenario. Several officials were very uncomfortable with this issue, perhaps an indicator of how essential the reliable supply of electricity is to industrial sector firms.

None of those interviewed considered industrial relocating to be a particularly likely option. Representatives from several industries did mention that supply constraints resulting in outages as described in our scenario would pose 
a serious threat to the operational integrity of the firms affected. In a situation similar to our scenario, it was thought that while firms might be forced to shut down operations that were rendered economically unfeasible due to repeated outages, it was uncertain whether a specific firm would actually relocate to another location. For most industries, it seems that the costs of relocating would be prohibitively expensive.

Several of the trade associations indicated that relocation under a supply constraint situation would be unnecessary, as other less disruptive responses would probably be more sensible. Firms within the paper, petroleum refining, and chemical industries might be more likely to turn to self-generation or cogeneration. The existence of supply constraints would probably accelerate pre-existing trends in this area. $(a, b)$

Within the aluminum industry electricity disruptions would certainly have a significant impact on a firm's ability to continue production costeffectiveness, particularly if supply disruptions occurred without prior warning. Electricity is a major component cost to aluminum production. As the cost of producing aluminum is very sensitive to the price of electricity, increases in the price of steadily available electricity may push production costs above the world price for aluminum. There seems to be a trend of aluminum production shifting overseas. This trend is expected to continue through the 1990's (Dept. of Commerce, 1985). A series of electricity supply constraints could hasten this trend.

\subsubsection{Costs of Relocation}

In relocating, industrial sector firms may incur very high overall costs. These costs include new plant and facilities, movement or purchase of equipment, set up costs, hiring of new employees, changes in distribution and delivery, transitional losses of production and efficiency, as well as many other components. Due to these high costs, relocation will have to be regarded as an extreme measure.

(a) Conversation with Mr. Sauer, Chemical Manufacturers Association, March 14, 1986.

(b) Conversation with Mr. Bruch, Petroleum Refiners Association, March 17, 1986. 
In considering whether to relocate, firms will have to weigh the costs associated against the costs likely to be incurred through expected outages. Obviously, the expected costs due to supply constraints will have to be very high to justify relocation. Due to the extreme heterogeneity of the industrial sector as well as large differences between individual firms within any given industry, the actual costs incurred through relocation will obviousiy vary considerably on a case by case basis. Costs of relocation could vary from a few thousand to tens of millions of dollars. As we were unable to identify any actual example of firms relocating due to electricity supply disruptions, we were not able to identify any point estimate of the costs associated with this type of activity. In cases where firms have relocated for other reasons, it is difficult to assess costs, as this information is generally viewed as proprietary.

\subsubsection{Potential for Peak Demand Reduction}

No significant potential for peak load reduction is expected from firms relocating abroad and elsewhere in the United States. Based on the results of our interviews of representatives from major electricity using industries, it appears that relocation would not be a viable response under a likely electricity supply constraint scenario. On a national basis, any potential relocation of firms due to peak electric constraints would probably not result in any saving in peak demand, since this would only result in a transfer of one component of peak demand from one area to another. On an international basis, however, the relocation of firms for any reason will certainly result in reductions in peak demand.

In both the cases of international and domestic relocation, even if this response were viable, it would be difficult to reasonably assess the impact on peak demand of industry relocation in response to peak supply constraints. A great many variables would come into play in any firm's decision to relocate. These factors include not just the price and availability of energy but also prices and availability of all other inputs as well as the demand for the firm's products and the firm's ability to compete. Since it is difficult to predict these factors over a time period of 10 years, it is impossible to estimate with any accuracy the impact that peak capacity constraints might have on 
a firm's possible decision to relocate. Given the complexity of the industrial sector as a whole, it is impossible to determine the effect that peak capacity constraints will have on the thousands of individual firms.

\subsection{SLMMARY OF FINDINGS}

In this chapter we identified areas of potential response by the indus trial sector to electricity supply constraints. Once identified these responses were discussed and levels of potential peak demand were estimated.

The industrial sector is arguably the most diverse sector of the economy. The level of electricity use, as with other inouts, varies considerably from firm to fim and industry to industry. Because of great diversity in the electricity needs of individual firms, the levels of actual response to electricity constraints will uitimately be determined on a firm by firm basis. Our analysis has necessarily been based on the broad view of the sector as a whole. Because of this, our estimates of potential peak load reduction should be interpreted cautiously. Table 4.12 summarizes these estimates.

There exists a strong link hetween many of the responses evaluated. The installation of onsite generation and cogeneration makes shifting the timing of demand or reducing the level of demand much cheaper for firms to undertake. Because of this, these estimates may include some double-counting.

Some of the responses evaluated show much greater potential than others. The adoption of onsite generation equipment shows perhaps the most potential for development due to new generation equipment and PURPA policies which provide incentives for cogeneration. Reduction of demand under interruption agreements also shows considerable potential. The level of response here may be heavily contingent on utility rate structures. Other responses such as high efficiency motors and alternate speed motor drives show some potentiat in peak demand reduction but more importantly underline the relationship between the adoption of other energy technologies and reductions in peak demand.

In general, it seems there is significant potential in peak load reduction in response to electricity constraints. More specific analysis is needed on an 
TABLE 4.12. Potential Peak Load Reduction of Responses Evaluated (In Gigawatts)

\begin{tabular}{|c|c|c|}
\hline Response & 1990 & 1995 \\
\hline $\begin{array}{l}\text { Reducing the level } \\
\text { of demand under } \\
\text { interruptible rates }\end{array}$ & $7.2-7.8$ & $8.5-9.4$ \\
\hline $\begin{array}{l}\text { Shifting the timing } \\
\text { of demand in response } \\
\text { to time-of-use rates }\end{array}$ & $0.7-1.6$ & $.9-1.9$ \\
\hline Cogeneration & (a) & 16.0 \\
\hline $\begin{array}{l}\text { Combined Cogeneration/ } \\
\text { Self Generation }\end{array}$ & $15.9-17.1$ & $23.8-26.3$ \\
\hline $\begin{array}{l}\text { High Efficiency } \\
\text { Motors }\end{array}$ & 0.2 & 0.5 \\
\hline $\begin{array}{l}\text { Alternate Speed } \\
\text { Motor Drives }\end{array}$ & 2.2 & 4.5 \\
\hline Relocation & (a) & (a) \\
\hline
\end{tabular}

(a) Not estimated due to insufficient data.

industry by industry and utility by utility basis in order to more accurately estimate the potential for each area of response. Also, further analysis could emphasize the roles of major factors such as fuel prices, capital costs and general economic growth as well as federal regulations and public utility commissions in determining levels of industrial response to electricity supply constraints.

\subsection{REFERENCES}

Adams, R. C., et al. 1983. The Direct Service Industries: Their Contribution to the Northwest Power System and Economy. Prepared for Direct Service by Battelle Pacific Northwest Laboratories, Richland, Washington.

Bureau of the Census. 1982. Census of Manufacturers' Fuel and Electric Energy Consumed. MC82-S-4(Part I), J.S. Department of Commerce, Washington, D.C.

Council of Economic Advisors. 1985. Economic Report of the President. U.S. Government Printing office, Washington, D.C. 
Davidson, K., and B. A. Hedman, 1984. "Natural Gas Cogeneration: Long-term Prospects." Paper prepared by Gas Research Institute, Chicago, Illinois.

Devine, W. 0., and D. A. Boyd. 1981. Costs of Electric Power Outages to Manufacturers. ORAU/IEA-81-9(M), Institute for Energy Analysis, Oak Ridge, Tennessee.

EPRI. 1980. Industrial Response with Time of Day Pricing: A Technical and Economic Assessment of Specific Load Management Strategies. EPRI-1573, Electric Power Research Institute, Palo Alto, California.

EPRI. 1981. Forecasting In-Plant Electricity Generation in the Industrial Sector, 1980-2000. EPRI EA-2163, Electric Power Research Institute, Palo Alto, California.

EPRI. 1982. Generating Capacity in U.S. Electrical Utilities: How is it Used? How Much is Needed Over the Decade? EPRI EA-2639, Electric Power Research Institute, Palo Alto, California.

Hirschberg, J. G., and D. J. Aigner. 1982. Econometric Analysis of Southern California Edison Company's Very Large Power Customers. Southern California Edison Company, Rosemead, California.

Jazayeni, A. 1984. Analys is of Impacts of Time-of-Use Rates for Large Commercial and Industrial Customer (0ver $500 \mathrm{~kW}$ Demand). Southern California Edison Company, Rosemead, California.

Mathtech, Inc. 1983. An Assessment of Factors Affecting Industrial Electricity Demand. Arlington, Virginia.

Mitchell, B. M., W. G. Manning, Jr. and J. P. Acton. 1977. Peak Load Pricing: European Lessons for U.S. Energy Pricing. Johns Hopkins Press, Baltimore, Maryland.

Moe, R. J., et al. 1986. The Electric Energy Savings from New Technologies. PNL-5665. Chapters 7 and 12, Prepared for the U.S. Department of Energy by Pacific Northwest Laboratory, Richland, Washington.

Peles, R. R., et al. 1984. The A-23 (SC-10) and AS.23 (SC-6) Curtailable Rate Options 1983 Analysis Report. Pacific Gas and ETectric, San Francisco, California.

Samsa, M. E., et al. 1978. Electric Service Reliability: Re Customer Perspective. ANL/AA18, Argonne National Laboratory, Argonne, IITinois.

Southern Caljfornia Edison (SCE). 1984. Analysis of Time of Use Rates for Large Power Commercial and Industrial Customers. Rosemead, Catifornia. 
U.S. DOE. 1981. Annual Report to Congress. DOE/EIA-0173 81/3, Department of Energy, Washington, D.C.

U.S. DOE. 1983a. Energy Projections to the Year 2010. DOE/PE-0029/2, Department of Energy, Washington, D.C.

U.S. DOE. 1983b. The Future of Electric Power in America: Economic Supply for Economic Growth. DOE/PE-0045, Department of Energy, Washington, D.C.

U.S. DOE. 1984. Annual Energy Review 1983. DOE/EIA-0383(83), Department of Energy, Washington, D.C.

U.S. OTA. 1983. Industrial Energy Use. OTA-E-198, Washington, D.C. 


\subsection{COMMERCIAL SECTOR RESPONSE TO ELECTRICITY SUPPLY CONSTRAINTS}

This chapter provides a preliminary and limited review of responses of the commercial sector to peak electricity supply constraints. This review describes actual responses of the commercial sector to electricity price increases and/or peak supply constraints. Based upon such experiences, the review estimates the potential for peak load reductions through responses in the future. The scope of the review is limited in the sense that 1) not all available literature is included and 2) the number of case studies for each response review is small. This analys is is pretiminary because the assumptions used to derive the potential for peak load reduction need to be further assessed.

Section 5.1 reviews the relative impact of the comercial sector on util-. ity peaks and compares the impacts of various end uses in the commercial sector on those peaks. Section 5.2 provides an overview of the five response areas selected for this study, noting the general aspects, interrelationships between the responses and related qualifications of the analysis. Sections 5.3 through 5.7 deal, respectively, with timing of electricity use (time-of-use rates), reductions in firm loads (interruptible rates), cogeneration for own building use, therma i energy storage and energy management systems. In these sections discussing the individual responses, the concept or the technology involved is explained first. It is followed with descriptions of selected studies. Customer participation, penetration of technologies, costs and benefits are then treated. Based upon such information along with additional assumptions, potential peak reductions are derived. Section 5.8 then provides a summary of the findings in the analysis, additional notes and caveats.

\subsection{BACKGROUND}

The commercial sector accounts for a large proportion of U.S. electricity use, even though its overall contribution to energy consumption is relatively small. In 1983, the commercial sector used 544 billion $\mathrm{kWh}$ of electricity, about $25 \%$ of total electricity use in the U.S. In terms of total energy, the commercial sector accounted for $16 \%$ of U.S. end-use energy consumption and $12 \%$ 
of U.S. total energy consumption in 1983. Department of Energy (DOE) projections of U.S. energy demand by sector in the year 1990 indicate that the commercial sector will account for $30 \%$ of U.S. electricity use, even though only $13 \%$ of total end-use energy consumption in 1990 is projected to be due to the commercial sector. In 1995, the corresponding shares are $29 \%$ for commercial electricity in total electricity, and $14 \%$ for total commercial-sector energy use in total U.S. end-use energy consumption (DOE 1985, Tabte A4, pp. 206-207). Estimates of electricity use by the commercial sector as a percentage of total commercial-sector energy use range from $37 \%$ to $44 \%$ over the next 10 years (DOE 1985).

According to 00E's mid-price increases and mid-economic growth scenario, commercial use of electricity will grow at about 3.5\% annual rate between 1983 and 1995 (Table 5.1, first two columns). In Table 5.1, EIA's electricity use forecasts through 1995 have been converted into average loads (average megawatts [MW]) and peak loads.(a) Total commercial-sector contribution to system peak loads is further divided into two categories: those attributable to existing building stocks as of 1983 and those attributable to new commercial buildings. This disaggregation is needed for use in developing the approximate potentials for peak load reductions of various responses by the commercial sector to peak supply constraints.

Summer peaks dominate commercial building load profiles and are especially severe in the late afternoon. Electricity uses in all commercial buildings, by end use, are, on the average, 30\% for air conditioning, $15 \%$ for space heating, $42 \%$ for lighting and $13 \%$ for other uses (DOE 1984c). For the sector as a

(a) Electricity use in kilowatt-hours are converted into average kilowatt demand by dividing by 8760 . The average kilowatt demand is divided by an average load factor to derive peak demand. The load factor is the ratio of average loads to peak loads. The U.S. commercial sector accounts for about one third of average electricity loads (DOE 1984a) and for about one third of summer peak loads. Since the ratio is one-to-one, it is reasonable to assume that the average load factor for the commercial sector is similar to the average load factor for all sectors. In the United States, average summer load factor is about 62\% (NERC 1984). 
TABLE 5.1. Commercial Sector Summer Peak Load Projections

\begin{tabular}{|c|c|c|c|c|c|c|c|c|c|}
\hline \multirow[b]{2}{*}{ Year } & \multicolumn{2}{|c|}{$\begin{array}{c}\text { Projected } \\
\text { Comerciol Sector } \\
\text { Conauption of } \\
\text { Dellyered Electriclly }\end{array}$} & \multirow{2}{*}{$\begin{array}{c}\text { Comeercinl } \\
\text { Congumption } \\
\text { Eriot lng 1n } \\
\text { l903 } \\
\left(10^{9} \mathrm{kwh} / \mathrm{yr}\right)\end{array}$} & \multirow{2}{*}{$\begin{array}{l}\text { Curlative } \\
\text { New } \\
\text { Comercin1 } \\
\text { Congueptlon(c) } \\
\left(10^{9} \text { wh/yr) }\right.\end{array}$} & \multirow{2}{*}{$\begin{array}{l}\text { Average } \\
\text { Faisting } \\
\text { Demand(d) } \\
\left(10^{3} \text { wis) }\right.\end{array}$} & \multirow{2}{*}{$\begin{array}{l}\text { Averoge } \\
\text { Nex } \\
\text { Dewand(e) } \\
\text { (I03 } 10^{3} \text { ) }\end{array}$} & \multirow{2}{*}{ 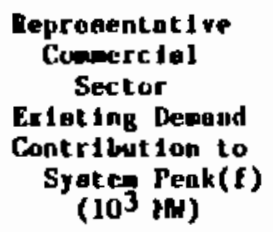 } & \multirow{2}{*}{ 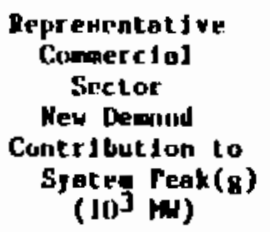 } & \multirow{2}{*}{$\begin{array}{c}\text { Total } \\
\text { Repreacntotive } \\
\text { Comercial Sector } \\
\text { Coneribution to } \\
\text { Syoten Peak(h) } \\
\text { (10 (10) }\end{array}$} \\
\hline & $\left(10^{15} \mathrm{bew} / \mathrm{jr}\right)^{(a)}$ & $\left(10^{9} \text { null } / y^{r}\right)^{(b)}$ & & & & & & & \\
\hline $\begin{array}{l}1983 \\
1984 \\
1985 \\
1986 \\
1987 \\
1988 \\
1989 \\
1990\end{array}$ & $\begin{array}{l}2.12 \\
2.36 \\
2.45 \\
2.51 \\
2.58 \\
2.65 \\
2.73 \\
2.81\end{array}$ & $\begin{array}{l}621 \\
691 \\
718 \\
735 \\
756 \\
776 \\
600 \\
823\end{array}$ & $\begin{array}{l}621 \\
621 \\
621 \\
621 \\
621 \\
621 \\
621 \\
621\end{array}$ & $\begin{array}{r}75 \\
97 \\
114 \\
135 \\
155 \\
179 \\
202\end{array}$ & $\begin{array}{l}70.9 \\
70.9 \\
70.9 \\
70.9 \\
70.9 \\
70.9 \\
70.9 \\
70.9\end{array}$ & $\begin{array}{l}-6.0 \\
11.1 \\
13.0 \\
15.4 \\
17.7 \\
20.4 \\
23.1\end{array}$ & $\begin{array}{l}114.4 \\
114.4 \\
114.4 \\
114.4 \\
114.4 \\
114.4 \\
114.4 \\
114.4\end{array}$ & $\begin{array}{l}12.9 \\
17.9 \\
21.0 \\
24.8 \\
28.6 \\
32.9 \\
37.3\end{array}$ & $\begin{array}{l}114.4 \\
127.3 \\
132.3 \\
135.4 \\
139.2 \\
143.0 \\
147.3 \\
131.7\end{array}$ \\
\hline 1995 & 3.20 & 937 & 621 & 316 & 70.9 & 36.1 & 114.4 & 58.2 & 172.6 \\
\hline
\end{tabular}

(a) LOB 1985 (Mid-Prico/HId-Pcanonic Growth Scenerto).

(b) Uaing canverelon factor of 3414 Btu per wh.

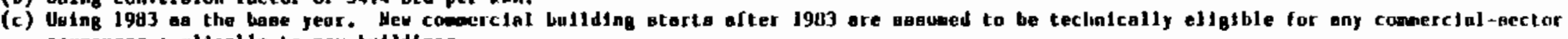
cespouses epplicalile to new busldings.

(d) Exlating comerciel congugut ton divided by 8760.

(e) Mer comerctal cunauntion divided by g7fo.

(f) Obtalued by dividing average extat ling deagind by load factor of 0.62 (NERC 1964).

(g) Olbtalned by dividing average new deand by load factor of 0.62 (NFRC 1984).

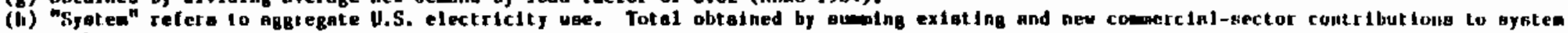
peak. 
whole, twice as much electricity is used for air conditioning as for space heating. On an average annual basis, lighting is the dominant electricity end use.

The amount of electricity used by a commercial building depends on a number of factors, including whether or not it uses electricity for space heating as well as space cooling, the building size, the building's use, climate and location, HVAC efficiency, building envelope and such other factors as what conservation measures are already incorporated into building design. Table 5.2 shows overall commercial-sector electricity use, by building type. The building categories in Table 5.2 are insufficiently disaggregated to demonstrate the differences between building types in energy use. However, it does show more detail regarding the components of the 2.39 quads of electricity consumed, in 1984, by the commercial sector.

TABLE 5.2. Commercial Sector Electricity Use by Building Type, 1984

\begin{tabular}{|c|c|c|}
\hline Building Type & $\begin{array}{c}\text { Electricity Use } \\
\left(10^{15} \text { Btu }\right)\end{array}$ & $\begin{array}{l}\text { Percentage of } \\
\text { Total Commercial Sector } \\
\text { Electricity Use } \\
(\%)\end{array}$ \\
\hline $\begin{array}{l}\text { Office, educational build } \\
\text { laboratories, health clin } \\
\text { and some public buildings }\end{array}$ & 0.90 & 38 \\
\hline Retai l/wholesale & 0.68 & 29 \\
\hline Warehouse & 0.32 & 14 \\
\hline $\begin{array}{l}\text { Assembly buildings, hotel } \\
\text { hospitals, parking } \\
\text { garages and jails }\end{array}$ & 0.46 & 19 \\
\hline Total & 2.35 & 100 \\
\hline
\end{tabular}

Source: DOE 1985. 
Table 5.3 shows average electricity use intensity for commercial buildings in the United States by building type and by use of electricity. Electricity use intensity for all commercial buildings (that use electricity) ranges from $7 \mathrm{kWh}$ per square foot for places of assembly, to $31 \mathrm{kWh}$ per square foot for

TABLE 5.3. Average Electricity Use Intensity for Commercial Buildings in the U.S. by Building Tyge and by Use of Electricity, 1979 (kWh/square foot/year)

\begin{tabular}{|c|c|c|c|c|}
\hline & $\begin{array}{l}\text { A11 Commercial } \\
\text { Buildings That } \\
\text { Isse Eiectricity } \\
\text { (1) } \\
\end{array}$ & $\begin{array}{c}\text { Commercial } \\
\text { Buildings } \\
\text { That Heat } \\
\text { with Electricity } \\
\text { (2) } \\
\end{array}$ & $\begin{array}{l}\text { Commercial } \\
\text { Buildings } \\
\text { That Do Not } \\
\text { Heat with } \\
\text { Electricity } \\
\text { But Air Con- } \\
\text { dition with } \\
\text { Electricity } \\
\text { (3) } \\
\end{array}$ & $\begin{array}{l}\text { Commercial } \\
\text { Buildings } \\
\text { That Do } \\
\text { Not Heat } \\
\text { or Air Con- } \\
\text { Condition } \\
\text { with } \\
\text { Electricity } \\
\text { (4) } \\
\end{array}$ \\
\hline Offices & 17.3 & 17.6 & 17.0 & 19.9 \\
\hline Retai1/Services & 11.1 & 18.2 & 9.4 & 5.9 \\
\hline Food Sales (b) & 31.4 & 35.5 & 27.0 & 25.2 \\
\hline Education & 8.2 & 10.3 & 9.4 & 4.7 \\
\hline Health & 19.9 & 17.9 & 27.1 & -- \\
\hline Lodging & 16.7 & 25.8 & 13.2 & 9.7 \\
\hline Warehouses & 12.9 & 16.7 & 13.2 & 8.8 \\
\hline Assemb ly & 7.0 & 9.4 & 6.5 & 6.7 \\
\hline $\begin{array}{l}\text { Automotive Sales/ } \\
\text { Services }\end{array}$ & 10.3 & 7.6 & 13.2 & 8.5 \\
\hline Other & 18. 5 & 19.6 & 20.2 & 8.5 \\
\hline Vacant & 9.7 & $\cdots$ & -- & 8.2 \\
\hline $\begin{array}{l}\text { All Commercial } \\
\text { Buildings }\end{array}$ & 12.9 & 17.0 & 12.9 & 8.8 \\
\hline $\begin{array}{l}\text { (a) Reported by } \\
\text { Table 7; Col } \\
\text { Conversion } \\
\text { (b) Includes res }\end{array}$ & $\begin{array}{l}\text { ga and Nieves } 19 \\
\text { (2): Table } 8 ; C \\
\text { tor used is } 3412 \\
\text { urants and groce }\end{array}$ & $\begin{array}{l}\text { Based on DOE } \\
\text { (3): Table 9; } \\
\text { tu per kWh. } \\
\text { stores. }\end{array}$ & $\begin{array}{l}\text { 1984a. Col. } \\
\text { Col. (4): Ta }\end{array}$ & $\begin{array}{l}\text { 1): } \\
\text { ble } 10 .\end{array}$ \\
\hline
\end{tabular}


a food sales category including hoth restaurants and grocery stores. As is to be expected, commercial buildings that use electricity for both heating and cooling tend to be more electricity intensive $(17.0 \mathrm{kWh}$ per square foot) than commercial buildings that use electricity for cooling but not for heating (12.9 kWh per square foot).

Differences in buflding usage cause variations in time-of-day and seasonal demand by building type. Characteristics of various building types that affect building energy demand are discussed hriefly below. The building types mentioned individually are: office buildings, sales, nursing homes/motels/hotels, hospitals, schools, and places of assembly.

Office buildings tend to have characteristic, time-related load swings. Demand drops on nights and weekends. Lighting systems are large electricity users; their predominant function is to enhance worker productivity. Heat gain from lighting, occupants and through windows tends to be significant. Cooling demand can be large because of these large heat gains.

Sales are the primary usage of commercial buildings ranging in size from small stores to regional malis. Department stores and strip shopping centers are also encompassed by this classification. Buildings used for sales tend to have longer hours of operation than office buildings, although there are still distinct daily patterns of energy usage. The primary purpose of lighting is to display merchandise to customers. Building electricity use tends to be dominated by lighting loads (Binkley et al. 1982a).

Nursing homes, motels and hotels all tend to be relatively energy intensive (Binkley et al. 1982b). Energy-using equipment operates 24 hours per day, as is the case in residential buildings. High domestic hot water consumption characterizes all three building types. Fans and ventilation systems also tend to have relativeiy higher energy requirements in nursing homes, moteis and hotels than in other commercial buildings.

Hospitals also operate for 24 hours per day. They tend to be heating dominated. High heating requirements in hospitals are partiy attributable to the 
need to maintain humidity at comfortable levels for patients (Binkiey et al. 1983). Precise environmental control of temperature and humidity is critical to a hospital's effectiveness as a place of recovery.

Schools tend to have highly variable electricity loads between rooms and at different times of day. Loads depend on whether or not a room is occupied, as well as on how many people are in the room and what they are doing. An auditorium has different energy requirements depending on whether it is in use for a theater production, an assembly or stage crew. School rooms also tend to have specific lighting needs for student desks, chalkboards and other areas. In some parts of school buildings, ventilation requirements are relative?y high.

Religious buildings and places of assembly tend to be occupied sporadically. There may be no load for most of the week but large loads on days of assembly. Many religious buildings are older and have relatively poor insulation (Spielvogel and Rudin 1984). Energy bills can constitute a large proportion of the congregation's budget.

Electricity supply constraints would likely disrupt the operation of some commercial buildings more than others. For example, assured electricity supplies are crucial to hospital functions; disruption of electricity service can result in patient deaths unless a functioning back-up system is in place. On the other hand, a power outage during business hours may hardiy affect a church or synagogue. Thus, some portions of the commercial sector may respond differently than others to capacity constraints.

The costs of capacity shortfalls to the commercial sector have been estimated to range from $\$ 1.47$ per $\mathrm{kWh}(1981 \$)$ to $\$ 62.07$ per $\mathrm{kWh}(1981 \$)$ in United States studies (Sanghvi 1982). In the only commercial-sector study cited by Sanghvi (1982) with the entire USA as scope, the cost of a one-hour outage was $\$ 12.21$ per $\mathrm{kWh}(1981 \$)$, on average, for all commercial buildings. Office buildings had a somewhat higher than average outage cost of $\$ 15.00$ per kWh (1981 \$). Survey techniques were used by researchers at IEEE to arrive at these cost-of-outage estimates. 
Measures that would be taken in the commercial sector to respond to supply constraints would depend on the costs incurred by the constraints, on the availability of alternatives, and on the lead time. Assuming several years' notice, as in the scenario depicted in Chapter 1.0, many alternatives to electricity use at peak periods might be developed.

\subsection{OVERVIEW OF COMMERCIAL SECTOR RESPONSES TO ELECTRICITY SUPPLY CONSTRAINTS}

If the supply constraint scenario postulated in Chapter 1.0 becomes a pending reality, two phenomena are likely. One is that the prices of electricity are likely to rise substantially, especially during the peak period when there is heavy demand and cost of generation is high. The other likely outcome is that there would be brownouts or rotating load shedding schemes. When confronted by the prospect of large price increases in its electricity supply, particularly during the peak period, conmercial businesses are likely to respond in various ways. Among the six general response areas discussed in Chapter 1.0, the following five will be analyzed in this Chapter:

- shifts in timing of commercial activities in response to time-of-use (TOU) rates

- reductions in maximum levels of electricity use in response to interruptible rates

- cogeneration for use in supplying own needs, especially during peak periods

- thermal energy storage to reduce peak loads

- energy management systems to increase the efficiency of electricity use through better control.

While the nature and potentials of these responses for commercial users of electricity are detailed in Sections 5.3 through 5.7, several aspects need to be noted here. First, some of these responses need to be initiated by the local utility serving the commercial businesses, while others can be initiated by the businesses themselves. Tou rates and interruptible rates are utility programs for which participation can be mandatory or optional. Thermal energy 
storage and energy management systems can generally be initiated by the commercial customers themselves without utility involvement. However, in many cases, the local utility is involved in terms of giving technical assistance and financial incentives. In the case of cogeneration, the utility needs to be involved in purchasing the excess power, if any, from the cogenerating commercial customer.

Next, some of these responses are likely to be interrelated in two ways: 1) Actions taken in one response area may preclude the adoption of actions, or diminish the potential energy savings or load reductions, in other response areas. For example, if a commercial customer is participating in an optional TOU rates and has already shifted a substantial portion of its load from the on-peak period, the possibility for this customer to further reduce load under an interruptible rate scheme is lowered. 2) Actions taken in one response area may stimulate the adoption of actions, or enhance the potential energy savings or load reductions, in other response areas. As an example, the higher demand and energy charge (price) during on-peak periods under ToU rates may lead to more instances of cogeneration, thermal energy storage, or installation of energy management systems. Another example in this case is that, when an automated EMS is installed, it allows the building operation personnel to better take advantage of interruptible rates and, thereby, induces firms to participate in the latter program.

A third aspect to note involves response areas not included in this analysis for the commercial sector. Some are not included because they are judged to be not very applicable to the commercial sector in general. One example is the relocation of the business to another region where electricity supply is more plentiful and prices are lower. Since commercial businesses generally serve the local population and the basic industries such as manufacturing, agriculture and mining, as well as serving other commercial businesses, and since electricity costs are often only a small part of the costs of doing business for commercial firms, it is not realistic to assume that relocation is a viable option for dealing with electricity supply constraints. Further, if relocation does occur, the business is often serving a different geographical market. 
Fuel switching from electricity to oil or natural gas, other than the cogeneration option, which is addressed in this analysis, may involve substantial retrofitting and disruption of on-going business operations. As a result, fuel switching is not often cost effective for commercial firms.

Other possible responses were not analyzed because of time and resource constraints. These responses include direct load control by the utility and more efficient building conservation technologies such as the heat pump, better insulation, window glazing, and daylighting.

Given the above considerations, the following sections treat, in sequence, TOU rates, interruptible rates, cogeneration, thermal energy storage, and energy management systems. In each of the sections, 1) the concept or the technology is explained; 2) selected cases are described; 3) utility customer participation is discussed for Tou rates and interruptible rates, and 4) ranges of costs and benefits are discussed in the other response areas. Finally, the potential for reducing peak load is explored, and rough estimates of potential reductions nationwide are derived.

\subsection{SHIFTING THE TIMING OF ELECTRICITY USE}

Because of the way utility rates are determined, time-of-use (TOU) rates for commercial customers are generally combined with those of industrial customers. Electric rates are usually segregated by the customers' maximum monthly $\mathrm{kW}$ demand. The group of the largest users is likely to have more industrial customers than commercial customers. As the maximum $\mathrm{kW}$ demand per customer decreases, the proportion of commercial customers increases. For this reason, the distinction between TOU rates for commercial customers and those for industrial customers is a matter of degree.

\subsubsection{The Concept of Time-of-Use Rates}

The underlying concept of TOU rates is that electricity supplied at different times of the day, the week, or the year are different "commodities" because of the differences in cost of generating it and supplying it to the customers. During peak hours, additional generation from costiy combustion 
turbines is required, resulting in higher average cost of production per kwh of electricity. With TOU rates, on-peak electricity is charged a higher price.

In general, on a daily basis, the time is divided into three periods: peak, partial peak, and off peak. The peak period is likely to be from the late morning to the early evening, but the actual time of the day designated as the peak period depends upon the season and local system conditions such as air conditioning load or heating load.

For Pacific Gas and Electric Company (PG\&E 1983a) the summer (May 1 through September 30) peak period is defined as from 12:30 p.m. through 6:30 p.m. Monday through Friday, except for holidays; and the winter peak period is from 4:30 p.m. to 8:30 p.m. Monday through Fridays, except for holidays. The off-peak period is from 10:30 p.m. to 8:30 a.m. Monday through Saturday, and all day on Sundays and holidays.

For Potomac Electric Power Company (PEPCo 1984), the summer period is from June through September and the winter period from October through May. The peak hours are 12:00 noon to $8: 00 \mathrm{p} \cdot \mathrm{m}$. Weekdays (except holidays) and the off peak hours are 12:00 midnight to $8: 00 \mathrm{a} \cdot \mathrm{m}$. weekdays and all day on Saturdays and holidays.

Under TOU rates, the price of electricity charged a customer has several different components: customer charge, demand charge, energy charge and distribution charge. Customer charge and distribution charge are usually fixed, while energy charge definitely is time-differentiated. Depending on the size of the customer $\mathrm{kW}$ demand, the demand charge may or may not be time-dependent.

Table 5.4 provides an example of actual 1984-85 rate schedule from PEPCo, applicable to customers whose maximum 30 minute demand is greater than $1000 \mathrm{~kW}$. In this case, the peak energy charge is about 2.1 times that of off-peak during the summer, and about 1.8 times during the winter. The partial or intermediate peak energy charge is about 1.6 times that of off-peak charge for both summer and winter. The peak demand charge (production and transmission charge) is only applicable to the summer season. 
TABLE 5.4. PEPCo's Schedule DC - GT

\begin{tabular}{|c|c|c|}
\hline & Summer & Winter \\
\hline A. Customer Charge & $\$ 280$ per month & $\$ 280$ per month \\
\hline $\begin{array}{l}\text { B. Energy Charge } \\
\text { On Peak } \\
\text { Intermediate Peak } \\
\text { Off Peak }\end{array}$ & $\begin{array}{l}6.218 \text { cent } / \mathrm{kWh} \\
4.604 \text { cent } / \mathrm{kWh} \\
2.935 \text { cent } / \mathrm{kWh}\end{array}$ & $\begin{array}{l}5.210 \text { cent } / \mathrm{kWh} \\
4.601 \text { cent } / \mathrm{kWh} \\
2.935 \text { cent } / \mathrm{kWh}\end{array}$ \\
\hline C. Demand Charge & $\$ 9.80$ per $\mathrm{kW}$ & \\
\hline D. Distribution Charge & $\$ 6.00$ per $\mathrm{kW}$ & $\$ 6.00$ per $\mathrm{kW}$ \\
\hline
\end{tabular}

Sources: PEPCo 1984.

Economic theory suggests that, the larger the electricity price differential between peak period and of $f$-peak period, the larger the amount of peak electricity use reduction. Survey data seem to support this relationship. In a 1977 survey, 55\% of the commercial customers said that they would try to shift peak load use under a $4: 1$ price ratio when the peak period is from $10 \mathrm{a} . \mathrm{m}$. to $8: 00 \mathrm{p.m}$. At a 25:1 price ratio, an additional 13-15\% of the customers would try to shift (AER/HBRS 1984, p. 5-14).

\subsubsection{Description of Cases}

This subsection first describes specific TOU rates applicable to commercial customers from two utilities. A summary of the results of TOU rates from other utilities follows, emphasizing the estimates of load shifting away from the peak period to the of $f$-peak period.

\subsubsection{Case 1: PG\&E's Time-of-Use Rates}

PG\&E's time-of-use rates started in February, 1977 with a mandatory program (which applied across the state of California) for its very large cus tomers with maximum demands greater than $4,000 \mathrm{~kW}$. Initially, it was called the A-17 rates; currently, it is called the A-23 rates. In 1979, there were 130 customers with a class demand at the time of system peak of a little over $1000 \mathrm{MW}$, about 10\% of the system demand (Creighton, T. E., 1979. p. 13-15). In 1983, there were 140 customers in the rate schedule, and the combined class demand at system peak is over 1000 MW, accounting for about $7 \%$ of total system 
peak Toad (PG\&E, 1983a, p. C-1). Most customers under this schedule are industrial firms, although a substantial number are commercial customers.

In 1979, PG\&E established Schedule A-22 TOU rate for about 700 customers with demands between $1,000 \mathrm{~kW}$ and $4,000 \mathrm{~kW}$. Included in these customers are very large retail establishments, large hotels and motels. In 1981, Schedule A-21 TOU rate was established for approximately 1,300 customers with demand between $500 \mathrm{~kW}$ and $1,000 \mathrm{~kW}$. Included are commercial customers such as merchandise stores and educational services.

Participation in TOU Rate Schedules A-21, A-22, and A-23 is mandatory. In addition, there are also interruptible options and a Group Load Control program which is explained in the next section. Altogether, about $30 \%$ of PG\&E's load in California is under time-varying rates (PG\&E, 1983a. Pp. C-1 and C-2).

During 1981-82, PG\&E conducted an experimental study of TOU rates for Small commercial customers with monthly maximum demand of less than $500 \mathrm{~kW}$--the A-20 Rate Schedule. Based on the results derived from an analysis of the experiment, PG\&E proposed and obtained authorization to implement voluntary TOU rates for small comercial customers--Schedule A-7 and A-21A--in 1984.

The early result in PG\&E's TOU rates for very large customers are estimated, on the average, to be $1.8 \%$ shifted from the winter peak hours and $2.7 \%$ shifted from the summer peak hours (Creighton 1979 p. 12-25). Analysis of the experimental small comercial TOU rates shows that on-peak demand will be reduced by $2 \%$ by adopting the TOU rates, and on-peak energy use will be reduced by 2.5 to $3.4 \%$. Partial-peak use would remain unchanged. Off-peak energy use would increase by 4 to $7 \%$ (PG\&E 1983a, p. 2).

5.3.2.2 Case 2: Wisconsin Power and Light

In 1977, Wisconsin Power and Light (WPL) implemented TOU rates for 140 of its Targest commercial and industrial customers with demand exceeding $500 \mathrm{~kW} \mathrm{a}$ month. The peak period was from $8 \mathrm{a.m}$. to $10 \mathrm{p.m}$. Monday through Saturday, excluding holidays. The on-peak/off-peak energy charge ratio is $2: 1$. The onpeak/off-peak demand charge is also $2: 1$.

Al though most of the large customers are industrial firms, there are some commercial customers included in the TDU rates. For example, out of the 140 
included in the program, 55 customers had off-peak demand exceeding on-peak demand, with the aggregate excess off-peak $\mathrm{kW}$ per year of $268 \mathrm{MW}$. Included in these latter 65 firms are warehouses, durable good wholesale out lets, general merchandising stores, food stores, and hoteis or other lodging. For the group as a whole, it was estimated that the group of firms shifted hetween 8 to $10 \%$ of its class on-peak demand to off-peak period. The shift in energy use from on-peak to off-peak is estimated to be $6.1 \%$.

\subsubsection{Results from Other Cases}

Some of the results for other cases in terms of shifts in peak energy and demand can be summarized. For San Diego Gas and Electric Company, its TOU rates for very large customers with demand exceeding $4500 \mathrm{~kW}$ involved a demand charge of $\$ 6.41$ per $\mathrm{kW}$ and a peak/off-peak energy charge of $1.17: 1$ in $1977-$ 1978. Overa11, these customers reduced on-peak energy use by $1.7 \%$ and on-peak demand of $2.6 \%$ as a result of Tou rates (DeSimone et al. 1979, p. 13-53). In 1981, the relative off-peak energy use increased by $1.6 \%$ and the on-peak demand and coincident demand decreased by $1 \%$ (Studivant 1982, pp. 9-11).

Southern California Edison reported that their large customers as a group reduced peak $\mathrm{kW}$ by $1.6 \%$ in the summer and $0.6 \%$ in the winter (Aigner and Poirie 1979, p. 4-12).

\subsubsection{Customer Participation}

TolJ rates can be mandatory, optional, or experimental. The experimental rates are usualiy precursors to either mandatory or optional Tou rates. In a survey conducted in September 1981, a total of 53 comercial Tou rates were identified. Among those identified, 6 were experimenta 1,15 mandatory, and 32 optional [Angel Economic Reports and Heberlein-Baumgartner Research Services (AER/HBRS) 1984, p. 5-9]. The mandatory programs are usually applied to the larger customers; some examples are PG\&'s A-21, A-22, and A-23 rates are explained above. Mandatory programs are also common in each of the Census Regions, except for the South. In the case of mandatory programs, participation is not an issue. 
In optional Tou rate programs, customer participation and load shifting behavior are important in determining the potential for peak load reduction. Some of the factors contributing to greater participation in optional Tou rates are as follows (AER/HBRS 1984, PP. 5-15 and 5-16):

- Belief that it is easy to change their operations schedule tends to lead to larger participation.

- Belief about saving money through TOU rates also stimulates participation.

- Perception that there is need for energy conservation or demand reduction is also important in motivating participation.

- Willingness to cooperate with, or to help, the local utility is also a positive factor in participation.

Actual participation in optional Tou rates have been generally low. In surveys conducted in 1981 and 1982, about $58 \%$ of respondents had four or fewer participants in the optional programs. Between 18 and $35 \%$ had no participants at al1 (AER/HBRS 1984, p. 5-17).

In a marketing study for PG\&E's optional TOU rates for small commercial customers, probabilities for participation were estimated by current rate schedule and by business type. For the group of smallest customers who were on the company's A-1 rate schedule, the predicted probabilities were between $14 \%$ and $19 \%$. For the somewhat larger customers who were on the A-12 rates, the probability ranged from $29 \%$ in miscellaneous building types to $56 \%$ in motel and hotel buildings. The resulting estimates of summer kW saved as percentage of total class load ranged from $8 \%$ to $14 \%$ for those on A-1 schedule and between $13 \%$ to $24 \%$ for those on the A-12 schedule (Charles River Associates 1984, Pp. $F-8$ and $F-11$ ).

\subsubsection{Potential for Peak Demand Reduction}

The discussion in Section 5.2 .2 and 5.2 .3 revealed that the effective reduction in peak load for commercial customers covered in mandatory Tou rates or participating in optional ToU rates ranged from $1.6 \%$ of sumer peak in the case of Southern California Edison to as high as $10 \%$ in the case of Wisconsin 
Power and Light. The projections for PGRE's small commercial TOU rates reached a high of 13 to $24 \%$. To be conservative, it is assumed that the effective load shift from peak period to off-peak period for customers either covered in mandatory TOU or participating in optional TOU rates is $2 \%$. It is further assumed that through 1995 about 20\% of commercial loads will be either covered by mandatory TOU rates or participating in optional TOU rates. Given these two assumptions, the potential peak reduction that could result from tou rates in the commercial sector would be about $0.4 \%$ of total commercial sector contributions to total system peak. Using the projected contribution to system peak load of the commercial sector shown in Table 5.1, these savings translate into peak load reduction of 0.61 GW in 1990 and 0.69 GW in 1995.

\subsection{REDUCING THE LEVEL OF ELECTRICITY USE}

Interruptible rates involve the right of the utility to interrupt electrical services to certain uses of its customers during periods of system need, usually during system peak or when reserve margin is low. In return for this reduced service reliability, the customers are compensated through lowered rates.

Interruptible rate schedules can be mandatory or voluntary. In voluntary interruptible rates, a level of firm service is agreed upon between the customers and the utility. At the interruption period, the customers are requested to reduce their loads to their respective firm service levels. If the customers actualiy reduce their loads accordingly, they receive the payments or credits towards their monthly bills. If they fail to reduce loads to their firm service levels, they are penalized in terms of higher rates. These rates are voluntary in two senses. First, individual customers can choose whether or not to participate in the program. Second, even if customers choose to participate, they can choose not to reduce their loads during load reduction period.

Interruptible rates are more common in the industrial sector. In the commercial sector such rates are a more recent phenomenon and are more likely to be voluntary than mandatory. The remainder of this section describes: 1) two 
cases of voluntary interruptible rates; 2) customers' acceptance of and participation in the programs; 3) barriers to program participation; and 4) the potential contribution of interruptible rates in reducing peak load in the commercial sector as a whote.

\subsubsection{Description of the Cases}

The two case studies of commercial sector interruptible rates described here, involve Pacific Gas and Electric (PG\&E) Company in northern California and Potomac Electric Power Company (PEPCo) in the Washington, D.C. area. Both utilities are summer peaking. PG\&E has a geographically dispersed service area with about 350,000 commercial and industrial customers; its 1983 summer peak was about $15500 \mathrm{MW}$. The service area of PEPCo is geographically concentrated with dense commercial and governmental development and essentially no major industrial facility. PEPCo's peak load is about $4000 \mathrm{MW}$; its large commercial/ governmental customers account for only about $10 \%$ of total customer counts and $75 \%$ of peak energy sales.

\subsubsection{Case Study 1: PG\&E's Group Load Curtailment (GLC) Program}

The Group Load Curtailment (GLC) program operated by PG\&E is an example of voluntary interruptible rates program. Under this program, participating groups of commercial and industrial customers are requested, during a curtailment period, to curtail their electricity demand to the group's predetermined level.

Program Features. The GLC program has five major features. They are the formation of cooperative groups of commercial and industrial customers, the performance of a GLC audit, the determination of the "Firm Service Level" (FSL), compensation and penalty, and computer monitoring and telecommunications networks. Each is briefly explained below (A. D. Little 1983, PP. 3-4; PG\&E 1983b, pp. 1-1 through 1-3).

Small groups of customers are formed and linked together by a computerized telecommunications network. During the curtailment period, PG\&E deals with the group as a whole, not with the individual members of the group. In effect, PG\&E can treat the combined loads of the group as a single load. Within the group, individual group members can help each other out. When the group is 
requested by PG\&E to shed loads to the group's FSL, each member of the group is expected to shed its load according to a predetermined list. If, for some reason, a member is not able to shed its load to reach the target, other members may be able to shed additional loads beyond their target levels, enabling the group as a whole to reach the group target.

Before each group is formed, a load management audit of each customer interested in participating in the program is performed at no cost to the customer. Based on the results of this audit and the expressed willingness of the customer to sustain curtailment at the time of system need, PG\&E negotiates a FSL with the customer. The aggregation of the individual members' FSLs becomes the group's FSL.

Customers participating in the GiLC program are compensated in two ways: they receive both a participation payment and a curtailment payment. These payments effectively reduce the rates they pay for electricity from the utility. The participation payment is made at a flat rate of $\$ 2$ per $\mathrm{kW}$ per month for each $\mathrm{kW}$ in excess of the group's FSL at the time of the group's maximum monthly coincident demand. This payment is made during the period when the group's agreement with PG\&E is in effect, regardless of whether actual curtailments take place or not. In contrast, the curtajiment payment is paid oniy when actual curtailment takes place. It is paid at the rate of 48 cents per $\mathrm{kW}$ per curtailiment hour, where curtailed load is caiculated according to the following formu?a:

$$
\begin{aligned}
\text { Curtailed Load }= & \text { (Predicted Load - FSL })+ \\
& 1 / 2 \text { (FSL - Average Load During Curtailment). }
\end{aligned}
$$

The group's predicted ioad is the average maximum on-peak demand for the five days before a curtailment (excluding weekends, holidays, and previous curtailment days).

If the group fails to reach and maintain its group load at the group's FSL during a curtailment period, then $P G \& E$ can penalize the group by: 1) adjusting upward the group's FSL by twice the difference between the group's maximum coincident on-peak kW demand during the curtailment period and the previously 
established FSL; 2) basing the curtailment payment on the difference between the predicted load and the maximum coincident on-peak kW demand during the curtailment period; and 3) employing the revised FSL for three consecutive curtailment periods or the three next occurring calendar months in the same period as the calendar month in which the group failed to meet its FSL.

Another feature of the GLC program is the computer monitoring and telecommunications network installed. Each participating customer is provided with a remote computer terminal connected in a network with other cooperative members and the utility. This networking allows the individual customers to identify $\mathrm{his} \mathrm{kW}$ demand in comparison with his individual FSL and communication regarding curtailment operations between the utility and the customer group.

Program Experience. In its second year of experimental and testing operation in 1982, the GLC program had four groups in PG\&E's San Francisco and East Bay divisions, involving 21 organizations and 33 buildings and plants. Group 1 in San Francisco and Group 2 in East Bay are composed of commercial buildings whose energy cost as a percent of revenues is low to medium. Group 3 includes both commercial and government buildings with low to medium energy cost component. Group 4 covers five process-related activities with high energy cost component in the East Bay division: three manufacturing facilities and two government-operated utility facilities (A.D. Little, Inc. 1983, PP. 26-30; PG\&E 1983, p. ES-1). Strictly speaking, Group 4 should be included in the industrial sector discussion in this report.

Each of the four groups of commercial and industrial customers participating in PG\&E's GLC program were requested to reduce their loads four times during the summer of 1982 . Some of the major findings with respect to the impact on demand reductions are summarized below (PGkE 1983):

- Average demand reductions at system peak are estimated to be in the following ranges: 


$\begin{array}{cc}\text { Group } & \text { Demand Reduction, MW } \\ 1 & 2.01-3.54 \\ 2 & 0.38-1.18 \\ 3 & 0.84-2.23 \\ 4 & 1.93-3.14\end{array}$

- Relative to their respective normal demands, the four groups achieved reductions ranging from $5 \%$ to $30 \%$. Moreover, the achieved percent reduction exceeded the amount requested:

\begin{tabular}{ccc} 
Group & \multicolumn{2}{c}{ Reduction, $\%$} \\
1 & $\frac{\text { Requested }}{4}$ & $\frac{\text { Achieved }}{2}$ \\
2 & 0 & 5 \\
3 & 0 & 12 \\
4 & 17 & 30
\end{tabular}

\footnotetext{
Note that Group 2 and 3 were not requested to reduce load during the curtailment days because they were operating below their respective FSLs. Nevertheless, they reduced loads anyway.
}

- Demand reduction in curtailment days achieved by the groups depended on the variables such as temperature, operating schedules, the firm service levels (FSL), and time of the day.

- The commercial groups (Group 1, 2, and 3) exhibited no payback phenomenon; i.e., subsequent to the curtailment, there were no noticeable increases in either demand or energy beyond what would normally have occurred.

- The commercial, owner-occupied buildings behaved differently than did the commercial, tenant-occupied buildings. The owner-occupied buildings were generaliy below their respective FSLs before curtailment 
operations and reduced their respective loads during curtailment. The tenant-occupied buildings were generaliy above the FSLs before the start of curtailment operations and did reduce their loads during curtailment.

5.4.1.2 Case Study 2: PEPCo's Commercial/Governmental Curtailabie Load Program

PEPCo had also successfully tested a curtailment program. As mentioned above, PEPCo has no major industrial facility in its service area. Hence, the emphasis of this program is on its commercial and governmental customers.

Program Features. Generally, the PEPCo program was similar to that of PG\&E. Customers interested in participating in the program received an energy audit conducted with the assistance of PEPCo engineering personnel to determine a Firm Service Level (FSL). PEPCo installed a Remote Terminal Unit (RTU) on the customer's premises, which was linked to a central controller via a privately leased telephone network.

During curtailment operations, the customers were notified via a signal sent through the telephone network to start load shedding manually or to automatically trigger a predetermined load shedding sequence through an automated energy management system (EMS). Participating customers were placed on an experimental rate schedule designed to provide incentives for participation and compensate customers for reducing load. The rate schedule also contained provisions for penalizing customers failing to reduce their demand to their FSL. when requested during the curtailment period.

There is one major difference between the PEPCo program and PG\&E program. Whereas PG\&E's program involves the group concept requiring the individual customers to form a group and to deal with the utility as a group, PEPCo deals with the individual participants directly. Dealing with the customers individually eliminates some of the problems associated with formation of the co-op. However, the potential benefits of group members helping each other out during curtailment operations to reach the group demand reduction target is also lost. 
There are also some differences with respect to the provisions of compensation and penalty. Compensation is based on the amount of load reduced from the participant's monthly peak to either the FSL or the maximum kW level that the customer demands during any curtailment period during the billing period, whichever is higher. Even if load is reduced to below the FSL, payment is still based upon the FSL, rather than the actual load. This is an incentive mechanism intended to induce the customer to commit to the lowest possible FSL. In 1984, the credit for curtailed load is $\$ 3.65$ or $\$ 4.60$ per $\mathrm{kW}$. If the customer failed to reduce demand to its $F S$, then a penalty rate of twice the monthly credit per $\mathrm{kW}$ will be assessed on the number of $\mathrm{kW}$ above the FSL.

Program Experience. The PEPCo curtailable load program started in 1982. During 1982-83, there were 31 participants in the program, although two dropped out before the summer of 1983. There were four major curtailments in 1982, ten 1983, and six through August, 1984. Five types of commercial/governmental customers were involved in the initial experiment during 1982-83: office buildings, master-metered apartments, large department stores, hospitals, and educational institutions. Some of the load reduction results (Johnson et al. 1985) are:

- Following the start of the curtailment period, the "hospital" load was reduced by about $2 \mathrm{MW}$ from about $4.7 \mathrm{MW}$. It then drifted upward by about $0.5 \mathrm{MW}$. At the end of the curtailment period, the load returned to its normal level.

- In an "office/motel complex", load was reduced from about $2.4 \mathrm{MW}$ to $1.8 \mathrm{MW}$, effectively shutting down the office portion of the complex.

- In a "major government agency", load was reduced by "a little over 20\%". This was typical of a Targe office building. In another office building, the reduction was one out of six MW, or $17 \%$.

5.4.2 Customer Acceptance and Participation

Since the interruptible rates described above are utility instituted programs in which participation by customers is voluntary, it is important to 
Jook at the customers' willingness to participate. The experience of PG\&E and PEPCo in this respect are briefly explained.

Through a series of structured telephone and onsite interviews with middle and upper management of 15 of the 21 organizations, an A. D. Little study identified two primary motivating factors for participation in PG\&E's GLC program (1983b, Chapter IV). The first motivating factor is a concern for assuring that there is a reliable source of electricity supply. Attitudes, interests and opinions are expressed in interrelated terms such as "avoiding brown out," "good public relations," "good citizenship," or "energy supply needs." These can be termed as the energy supply issues. The second motivating factor is the compensation in the form of participation and curtailment payments made by the utility to program participants.

Based upon these two primary motivating factors, participants are grouped into three classes. First, some firms are primarily motivated by the energy supply issues. For these firms, the financial compensation in tems of participation and curtailment payments are perceived as "icing on the cake"; they would still participate in the program even without the payments. of the 12 organizations with reliable information on this item, five belong to this group. Second, other finms or organizations are motivated by the combined incentives provided by the energy supply issue and the financial compensation. Three of the 12 organizations are in this category. In the other end of the continuum, there are those firms and organizations for which the financial incentives are the primary consideration. Without the participation and curtailment payments, four of the 12 firms would not have participated in the program.

PEPCo also conducted a survey following its experimental phase after the sumner of 1983 (Johnson et al. 1985, pp. 4-6). Participants perceived several benefits they derived from the curtailment program. Over half (52\%) mentioned better understanding of the facility operation as a benefit of the program. Dver one-third (38\%) picked the credit received for load reduction as a major benefit. The third most frequently mentioned benefit was the reduction in demand with better facility management. Other benefits mentioned included "proven ability to curtail load", "the energy analysis" performed, and "better 
relations with the utility". Depending on the type of respondents in the survey, the responses with respect to perceived benefits tend to differ. The operations personnel tend to emphasize the credit or payments, while the administrators tend to focus on the long-term benefit of the program, such as reduced demand, and improved facility operations.

With respect to future intentions to participate in the program, only $7 \%$ responded with outright refusal. $38 \%$ were unsure due to uncertainties concerning direction of program changes. Primary reasons for continuing to participate in the program included "good citizen", "save money", and "pleased with operations progress."

\subsubsection{Barriers to Program Participation}

The A. D. Little study identified a considerable number of disincentives to customer participation in PG\&E's GLC program (1983b, pp. 35-38). Some of these disincentives derive from the program features explained above. Others arise from the implementation and operation of the program. Included in the first category of disincentives are the following:

- the need to formally organize a co-op

- the complexity of the curtailment payment formula and its interrelationship with the FSL as well as participating customers' operating experience

- questions and doubt about the need and fairness of the penalty provisions in the program

- problems with long delays in GLC computer terminal maintenance, and with the computer network software.

Disincentives originating from the implementation and operation of the GLC program are as follows:

- uncertainty concerning PG\&E's motives in instituting the program

- lack of perception of a significant organizational comitment to the program by $P G \& E$

- lack of timely actions by PG\&E in response to group concerns 
- the complexity of program contracting

- equipment maintenance problems

- lack of clarity and consistency on information concerning program design

- significant investment in terms of personnel time on the part of potential program participants to conform to PG\&E's model of the program

- potential inconvenience to building tenants that could result from curtailment operations.

Based on the above disincentives and information derived from customers who had declined to participate in the program, three potential major barriers are identified (A. D. Little, 1983; p. 38):

First, the potential impact of curtailment operations on building tenants is a significant concern to organizations leasing building space to tenants. In some instances, this has precluded participation in the past. For the current participants, this could become a reason for terminating participation if significant tenant complaints result from curtailment operations. Second, some organizations would decline to participate in the program because of its penalty provisions. Third, in some cases, the requirement that the detailed contract be signed by an executive-level representative of a participating organization is a clear barrier to participation. In addition, any of the disincentives enumerated above could become a significant barrier, if the frequency of such occurrences rises in future implementation of the program.

Since the PEPCo program did not include the group concept, the difficulties associated with the formation of the co-op are not disincentives. Otherwise, many of the same disincentives in the PG\&E program were also encountered. For example, the following were mentioned by respondents to the survey:

- The incentives are inadequate.

- Insufficient manpower made curtailment difficult.

- There is a perception that PEPCo is promoting the program mainiy to benefit the utility itself. 
- The penalty provision in the FSL may be a negative aspect in that fear of a penalty resulted in setting a high FSL.

- The need to reach a FSL agreement tends to slow down the process of signing up participants.

\subsubsection{Potential}

According to PG\&E's experience, participating cormercial customers achieved load reductions during the curtailment period of 5 to $12 \%$. In PEPCo's cases, the reported reductions of individual customer loads reach as high as $40 \%$; the average reduction is undoubtedly much lower. Based on the experimental results and surveys on customer acceptance, PEPCo planned to expand the program to reach a target reduction of $200 \mathrm{MW}$ of sumrner peak, about $5 \%$ of its peak load.

To estimate the potential reduction in peak load from the commercial sector that can be derived from voluntary interruptible rates program such as those described in this section, it is assumed that about $20 \%$ commercial customers would participate in voluntary interruptible rates program, representing about $40 \%$ of commercial sector's contribution to system peak load. It is further assumed that interruptible rates will result in a $5 \%$ reduction in participating businesses' load during system peak. Combined, these two assumptions mean that about $2 \%$ of commercial-sector peak load can be reduced through an interruptible rate program. The commercial sector's contribution to system peak load is projected to be $151.7 \mathrm{GW}$ in 1990 and 172.6 GW in 1995 for the US as a whole (see Table 5.1, last column). Given the above assumptions, potential peak load reductions attributable to wider adoption of interruptible rates for the commercial businesses is estimated to he about $3.03 \mathrm{GW}$ in 1990 and $3.45 \mathrm{GW}$ in 1995 .

\subsection{ADOPTION OF SELF-GENERATION}

Will cogeneration displace utility electricity loads in the commercial sector as it is doing in the industrial sector? This section first defines cogeneration applications within the scope of this study's analys is of commercial sector responses to electricity supply constraints. It then discusses 
some preliminary experience with cogeneration of a hospital and of a university, and the results of a feasibility study of cogeneration for fast-food restaurants. Subsequently, the current and likely future availability, costs and effectiveness of cogeneration packages for selected categories of commercial buildings are evaluated. Finally, values are selected to represent the potential acceptance of this technology by commercial customers and the consequent potential for the technology to reduce peak loads.

\subsubsection{Cogeneration Opportunities within Scope of Study}

In comnercial buildings, as in the industrial sector, cogeneration technology uses fuel much more efficiently than conventional electricity generation. This higher efficiency is a result of the cogenerator's ability to use waste heat from onsite electricity generation to heat water, provide space heating and cooling, and supply any other thermal energy requirements. The conventional conversion of fuel to electricity is only 30 to $35 \%$ energy requirements. The conventional conversion of fuel to electricity is only 30 to $35 \%$ energy efficient; when cogenerators use excess heat from electricity generation, the energy efficiency of fuel use may reach 65 to $80 \%$ (Energy Managenent Technology 1984).

Cogeneration economics and energy savings vary according to whether the primary objective of the cogenerator is generation of energy for resale or to meet a building's own energy needs. According to the Public Utility Regulatory Policies Act (PURPA), utilities must buy back electricity from qualifying cogenerators if the cogenerators wish to sell excess generated electricity. Resale of electricity is a driving factor in the decision of some establishments to operate cogeneration equipment; in other cases, the resale guarantee is rarely, if ever, used, and the cogenerator's primary purpose is to meet some or all of an owned building's energy needs. Insofar as is possibie, this study focuses on cogeneration for supplying a building's own energy needs and does not consider resale of electricity to local utilities. Thus, in economic estimations, no credits are given for potential income from resale of electricity to a utility, even though the PURPA-mandated availability of this option has, 
in fact, had a positive impact on market acceptance of cogeneration. (a) Similarly, the scope of energy savings estimates is limited to a building's own reductions in electricity use; bought-back electricity supplies are not credited as savings.

\subsubsection{Description of the Cases}

This subsection presents an overview of three cogeneration applications. In the first case, a university installed cogeneration specifically to displace peak loads. The second case summarizes the experiences of a hospital in Texas with an experimental packaged cogeneration system. The third case describes the results of analyses of the feasibility of cogeneration in a fast-food res taurant. All three systems studied are powered by natural gas. Diesel fuel and light distillate oil may also fire cogeneration systems but are less commonly used. (b)

\subsubsection{Case 1: University of Richmond, Virginia}

The first case study is a cogeneration system at the University of Richmond in Virginia (Energy Management Technology 1985a). The system consists of a $720 \mathrm{~kW}, 1200 \mathrm{rpm}$ natural gas-powered engine generator set by Waukesha, a waste heat recovery boiler by Vaporphase, and a 560-ton (1971 kW) absorption chiller by York. The cogeneration equipment is operated during the summer period only, for a total of less than 1000 hours per year. The absorption chiller replaces an 800 -ton electric chiller and can be operated from a central steam plant when the engine generator is off. The cogeneration system replaces substantial amounts of utility-generated electricity at peak periods and reduces the peak demand charge for the entire year.

In simple terms, the system works as follows. The natural-gas powered engine generates electricity. Its waste heat is used by the waste heat recovery boiler to make steam. The steam drives the absorption chiller. The absorption chiller produces chilled water. The chilled water air conditions

\footnotetext{
(a) An exception is made for the fast-food restaurant case study. Electricity sales to the utility are credited as in the original studies.

(b) Interview with Mark Osterhout, Kem Equipment, Inc., March 1985.
} 
approximately 240,000 square feet of building space. In winter, the cogeneration equipment could heat approximately 160,000 square feet of building space.

The simple payback of the system is expected to equal 4.2 years. The capital costs of the system are $\$ 525,380:(a)$ equipment and construction cost $\$ 475,800$, and engineering costs $\$ 49,582$. Operation costs $\$ 25,839$ per year for the natural gas that fuels the generator and $\$ 5,000$ per year paid to a contractor for maintenance. Annual savings from using the absorption chilier instead of the old electric chiller are $\$ 8,916$. Annual demand and consumption savings depend on the utility's rate structure and amount to $\$ 148,017$ annually: $\$ 122,637$ annual demand savings and $\$ 25,380$ annual consumption savings. The overall savings in operating and maintenance costs is estimated to be $\$ 126,094$ per year. (b) The cogeneration system at the University of Richmond is estimated to reduce peak loads by approximately $1000 \mathrm{~kW}$. The average load is reduced by $300 \mathrm{~kW}$ due to the use of the absorption chiller. The $720 \mathrm{~kW}$ engine generator equipment is cycled as demand fluctuates to reduce electrical loads on the local utility's system.

\subsubsection{Case 2: Medical Center Del Oro in Houston, Texas}

The second case study is a 258-bed hospital in Houston, Texas (Gas Research Institute 1984a, 1985). A cogeneration package was recently installed at this Hospital Corporation of America-owned facility as part of a development program by the Gas Research Institute. The cogeneration system is expected to save substantial amounts of money for the Medical Center Del Oro Hospital. The cogeneration package was developed by Martin Cogeneration Systems, a subsidiary of Martin Tractor. It consists of a $500 \mathrm{~kW}$ reciprocating gas-fueled engine by Caterpillar, a 150-ton single-effect absorption chiller, and a control system. The control system automatically adjusts the amount of energy supplied by the cogeneration package in response to fluctuating energy demand.

\footnotetext{
(a) Reference year for dollar not cited in Energy Management Technology (1985a).

(b) In fact, start-up difficulties eliminated some savings the first year so that actual first-year savings are $\$ 85,000$.
} 
Simple payback is estimated to equal 4.0 years. The installed cost is approximately $\$ 600,000$. (a) Annual savings of approximately $\$ 150,000$ per year are expected; these savings may range as high as $\$ 200,000$ per year but will probably be somewhat lower, approximately $\$ 135,000$, the first year.

The costs and operating savings of this system may not be representative of future cogeneration packages. The cogeneration package at the Medical Center Del Oro is a field test system. It is probably more expensive than cogeneration packages of the future since it is a custom-designed trial system. In addition, the local gas company, Entex, Inc., is allowing a special research rate for the hospital. Entex, Inc. normally offers special rates for cogenerators, but in this case it is allowing a further rate cut of 4 dollars per thousand cubic feet for an 18 -month period.

The cogeneration package provides almost all of the hospital's hot water, 60 to $70 \%$ of its electricity all year, and up to $60 \%$ of summer air conditioning. Reduction in electricity use is approximately 409,000 kWh per month or $75 \%$. The average $\mathrm{kW}$ reduction is $560 \mathrm{~kW}$. (b)

\subsubsection{Case 3: Fast Food Restaurant Feasibility Study}

The third case study is of a fast-food restaurant in the East North Central region. (c) The study was initially conducted for restaurants in the McDonald's chain (Sievert Corporation 1983) and was modified somewhat for use in an analysis by the American Gas Association (1985). The technology is a $70 \mathrm{~kW}$ turbocharged Waukesha engine with a 30-ton Hitachi chiller-heater. Cost savings are calculated using an all-electrically operated restaurant base case and a part-gas, part-electric base case. The results for the all-electric base case are tested for sensitivity to initial system costs and to the price differential between gas and electricity. First costs, in constant 1983 dollars, are estimated at $\$ 150,000$ or $\$ 2140$ per $\mathrm{kW}$. Dperating cost savings are

(a) Reference year for dollar values not cited in Gas Research Institute (1984a, 1985).

(b) Calculated by: 12 months $/ \mathrm{yr} \times 409,000 \mathrm{kWh} / \mathrm{month}=560 \mathrm{~kW}$ 8760 hours/year

(c) Specific reference site is not cited in American Gas Association (1985); several locations are considered in Sievert Corporation (1983). 
estimated to range from $\$ 12,000$ to more than $\$ 50,000$ per year in the origina1 study, depending on which system is replaced (Sievert Corporation 1983). In the modified example by the American Gas Association (1985), payback ranges from 3.0 years to 5.9 years depending on the case tested. Operating cost differentials include sell-back of electricity to the grid due to the incorporation of this revenue in the original study. Estimated operating cost differentials are discussed in more detail below.

The following discussion refers to the modified example by the American Gas Association (1985). In all scenarios, system operation begins in 1985. A 15-year operating life is assumed. Future regional energy prices and inflation factors are extracted from The A.G.A.-TERA Fall 1983 Base Case. (a) Conventional costs include electricity and gas; cogeneration costs include electricity, gas, electric standby, operation and maintenance.

In the American Gas Association (1985) study, two economic measures are calculated for each fast-food restaurant scenario. The two measures are the real, after-tax, internal rate of return (IRR) and the payback. The following values are used for these calculations: loan interest, $11 \%$ annual inflation, 4.1\%; income tax, 50\%; accelerated depreciable life of cogeneration equipment, 5 years; accelerated depreciable life of boiler equipment, 15 years; tax credit on capital costs of cogeneration equipment, $10 \%$ (with a $95 \%$ depreciable base allowance); and insurance costs subtracted from cash flow, $2.2 \%$ of undeprecjated capital costs.

First consider a cogenerator system owned by two commercial customers: one a $40^{\prime} \times 90^{\prime}$ fast-food restaurant which without cogeneration would meet its energy needs with purchased gas and electricity, and the other an identical restaurant except that it would otherwise meet its energy needs with electricity only. For the gas-electric base case, the payback is 5.9 years, and the IRR is $8.89 \%$. Energy use is reduced by $16 \%$. For the all-electric base case, the payback is 4.1 years, the IRR is $18.36 \%$ and energy use is reduced by $32 \%$. All other things being equal, the benefits of replacing the all-electric system

(a) American Gas Association. 2983. The A.G.A.-TERA Fall 1983 Base Case. Arlington, Virginia. 
with cogeneration are greater, in this scenario, than the benefits of replacing the part-gas, part-electric system with cogeneration.

Next, consider a cogeneration system owned by the gas utility but technicaliy identical to the system discussed previously. Calculating paybacks and IRRs to the gas utility with an incentive to the end user of a $10 \%$ reduction in total annual energy bills, the American Gas Association (1985) derived the following estimates (all refer to an all-electric base case): IRR equal to $15.09 \%$ and payback equal to 4.4 years. Increasing the gas to electric energy price differential by $50 \%$ markedly improved the system's economics: IRR increases to $29.87 \%$ and payback falls to 3.0 years. The initial case is less sensitive to reductions in capital costs (from $\$ 150,000$ to $\$ 127,700$ ): IRR increases from $15.09 \%$ to $17.87 \%$, and payback falls from 4.4 years to 4.1 years. In al1 cases, the internal rate of return could warrant investment by a gas utility, provided that payback is sufficiently rapid.

\subsubsection{Range of Costs and Benefits}

Installed costs of cogeneration in the case studies on a per-kilowatt basis were extremely disparate: $\$ 525$ per $\mathrm{kW}$ for the university system, $\$ 1071$ per $\mathrm{kW}$ for the hospital system and $\$ 2140$ per $\mathrm{kW}$ for the fast-food restaurant system. To date, $\$ 1200$ to $\$ 2000$ per $\mathrm{kW}$ is typical of the costs for installed cogeneration in the commercial sector (Davidson 1984a).

Likewise, there does not seem to be a typical percentage peak load reduction. Most commercial builting cogeneration systems are likely to be smaller than $2 \mathrm{MW}$. None of the case studies has more than 1 MW capacity.

Payback in the case studies is generally approximately 4 years. Payback is extremely sensitive to the cost differential between electricity and gas; this differential changes significantly between regions of the country.

\subsubsection{Potential}

In general, cogeneration is economically attractive to the commercial user only when there are relatively constant baseloads, concurrent electric and thermal loads and relatively high costs of conventional energy. However, cogeneration economics are highly sensitive to rate structure so that even 
relatively sporadic operation during the peak demand period, as is the case at the University of Richmond, may be cost effective if sufficient demand charge penaities are thereby eliminated.

In estimates that roughly account for such factors as the ratio between thermal and electric loads, region of the country and relative stability of loads, the Gas Research Institute hypothesizes that some 253,800 commercial sites may be candidates for cogeneration (Kostrzewa 1984). The sites include hospitals, hotels/motels, supermarkets, restaurants with long hours of operation, nursing homes, large office buildings, apartment complexes with at least 20 units, shopping centers, laundries and educational facilities. These building types identified as potential sites for cogeneration are compatible with others mentioned by parties with similar interests (Davidson 1984a, Waukesha 1984).

The Gas Research Institute is reported to be spending more than $\$ 100 \mathrm{mil}$ lion per year (1985 doliars) in efforts to make cogeneration a more attractive option for smaller users (Dunckel 1984). Particular effort is devoted to the development of technically and economically improved packaged cogeneration systems for hospitais, fast-food restaurants and supermarkets (Davidson and Krauss 1985). These packages are already well into development stages and continue to show promise.

One study estimated that roughly $560 \mathrm{MW}$ of commercial and residential cogeneration capacity already may be installed at about 300 sites across the United States (Lawn 1983). This translates into about $1900 \mathrm{~kW}$ per site, higher than the three cases described above, which range from $70 \mathrm{~kW}$ to $1000 \mathrm{~kW}$.

To derive an approximate estimate of the peak load reduction potential of commercial-sector cogeneration, the following assumptions are made: 1) By 1990, about $2 \%$ of the 253,800 sites postulated by GRI as candidate sites would actually install cogeneration packages for peak shaving purposes. By 1995, about $5 \%$ would do the same. 2) On the average, the peak shaving capability of each cogeneration facility installed at commercial businesses is assumed to be 
$500 \mathrm{~kW}$. Combined, these two assumptions yieid potential peak reduction through cogeneration of 2.54 GW in 1990 and 6.35 GW in 1995. (a)

5.6 USE OF THERMAL STDRAGE

One simple way to reduce peak electricity demand by comercial buildings is to chill or heat a reservoir of water or some other suitable medium at offpeak periods, which at peak periods can be used to cool or heat the building in place of a conventional heating, ventilation and air conditioning (HVAC) system. This peak-shaving technology is called thermal storage. (b) Its potential for reducing electricity demand in commercial buildings at peak periods is analyzed in this section. Selected cases in which the use of thermal storage has reduced peak electricity demand are discussed first. Based on these cases and citations in more general literature, expected ranges of costs and peak-load demand reductions due to thermal storage systems are then identified. The technical and economic information is then combined to develop rough estimates of the potential magnitude of reductions in peak energy demand from thermal storage in commercial buildings for the U.S.

\subsubsection{Description of Cases}

The analysis begins with a discussion of relevant experiences with thermal storage in three locations. Thermal storage is most commonly used in the commercial sector for cooling, and in only one of the three case studies is thermal storage used for heating as well. All the utilities serving the case study locations are summer-peaking. In each case, four questions are answered: Is the thermat storage technology working, in terms of occupant comfort and

(a) A more in-depth study of commercial sector cogeneration potential is presented in a draft working paper Commercial Cogeneration: Predicted Capacity prepared by L. Sgnecci OTConnelT for the DOE Office of PoTicy Integration (January 1986). This study used a more rigorous methodology to estimate cogeneration capacity potential on a state by state basis for eleven types of commercial establishments. An estimate of 7 GW of additional commercial sector cogeneration capacity is derived for the 1985 to 1990 time frame. Though substantially higher than the 2.54 GW figure we estimate for 1990, it is in line with our estimate of 5.35 fW for 1995 .

(b) For general descriptions of thermal storage technology, refer to McCannon (1983), EPRI (1982) and Baltimore Aircoil (1984). 
maintenance requirements? What were first costs? What are the operating cost savings and any other benefits to the building? How much is peak load demand reduced, and what other benefits accrue to the servicing utility? Thermal storage is generally most cost effective for businesses that would otherwise experience large demand charges (higher electricity rates at times of peak demand). It is much more easily incorporated into a building at the time of construction than added to an existing structure, and in many cases the costs and technical constraints for a retrofit application are prohibitive. Therma storage is most beneficial to utilities, because it is an effective peakshaving method that may allow the delay or avoidance of costs of providing more peak capacity.

\subsubsection{Case 1: Small Office Building in California - Ice Storage}

The first case is an ice storage system in Livermore, California. (a) This DOE demonstration project effectively cools a one-story, 18,000 square foot office building (60-ton design cooling load) between 12:30 and 6:30 p.m. The remainder of the cooling load is met by a $40 \mathrm{hp}$, refrigeration-type compressor. The bank is pleased with the system's performance.

The incremental system cost was approximately $\$ 250$ per $\mathrm{KW}$ peak cooling load. (b) Were the building cooled entirely with a conventional system, peak demand would be at least $40 \mathrm{~kW}$ greater. In addition, $7 \%$ more energy would be required to provide the same amount of cooling. (c)

The customer is on a time-of-use schedule and saves money by avoiding most demand charges. (A peak period load of 4 to $9 \mathrm{~kW}$ remains in order to operate various electrical systems.) The servicing utility, Pacific Gas \& Electric

\footnotetext{
(a) Laybourn, D. R., and V. A. Baclawski. 1984. "The Benefits of Thermal Energy Storage for Cooling Commercial Buildings." Pacific Gas and Electric Company, San Francisco, California.

(b) At $3.52 \mathrm{~kW}$ per ton and 60-ton design load, this works out to $\$ 52,800$. The study was conducted in 1983-1984.

(c) Results from a computer simulation. The lower overall energy requirements of the thermal storage system are attributable to exceptionaliy efficient system design and would probably not occur with other thermal storage systems.
} 
(PG\&E), experiences a peak load reduction of no less than $40 \mathrm{~kW}$. The utility avoids a future investment to provide peak generating capacity of an estimated $\$ 1200$ to $\$ 1500$ per $\mathrm{kW}$.

\subsubsection{Case 2: Large Department Store in Maryland - Chilled Water Cooling.}

The second case is a chilled $\left(42^{\circ} \mathrm{F}\right)$ water cooling system being planned for a large department store in Baltimore, Maryland (EPRI 1982). The store is three stories and 127,000 square feet. Cool storage would eliminate the need to operate one of two $188 \mathrm{~kW}$ chillers during peak hours; i.e., it would meet half of this large commercial building's cooling requirements each summer day. The most likely application is for a new similar structure operated by the same business.

A preiminary assessment projects a net first cost of $\$ 63,411$ : $\$ 243,411$ as the installed cost of tanks, minus $\$ 180,000$ savings on first costs of the conventional air-conditioning system. This amounts to $\$ 337$ per $\mathrm{kW}$ peak cooling capacity. Likely operating cost savings are estimated (by the business) to equal \$7,617 per year, using the applicable utility rate schedule (which incorporates a customer charge, energy charge and demand charge). The simple payback is 8 years.

The project would remove $188 \mathrm{~kW}$ from the utility's load peak. In contrast, the electric utility total contract load, in summer months, ranges up to about $4000 \mathrm{MW}$.

5.6.1.3 Case 3: Education Building in New Mexico - Heat and Cool Storage

The third case is an 8-tank thermal storage system in the University of New Mexico's Mechanical Engineering building in Albuquerque (EPRI 1982). Four of the tanks can accommodate either heating or cooling. One 110-ton (387 kW) heat-pump chiller and one 55-ton (193 kW) heat-pump chiller are normally operated only during off-peak (nighttime) hours. Several special features characterize this building: roof-top solar collectors are also part of its energy management strategy. In addition, peak cooling loads are lower than for typical commercial buildings in similar climates because: 
1. Heat gain from lighting is low since occupants frequently turn unused lights off.

2. Heat gain from other internal sources (e.g., duplicating and office equipment) is also lower than average.

3. Few people are in the building during summer afternoons, whereas in other commercial buildings this is typically the highest demand period for cooling.

Over a monitored six-month period, the load-managed system was $14 \%$ less expensive than a comparable conventional system. In one four-month heating period (January through Apri1), $23 \%$ of the heating load was provided by heat pumps through thermal storage. In cooling months, $70 \%$ of the building's total energy consumption occurred off-peak.

Peak demand at the Public Service Company of New Mexico occurs at different times of day from the loadmanaged building's times of maximum demand. The effect is especially pronounced in the summer, when the Mechanical Engineering building's demand drops from about 175 to $200 \mathrm{kw}$ (before $6 \mathrm{a.m.)}$ to about $100 \mathrm{~kW}$ during the daytime, while PNM loads are peaking at 900 to $1000 \mathrm{MW}$ from significantly lower nighttime loads.

\subsubsection{Range of Costs and Benefits}

This section arrives at a set of assumptions regarding first costs, simple payback to customers and peak-load reductions for thermal energy storage (cooling only). These assumptions are used to construct a scenario, in Section 5.6.3, of the overall potential for thermal energy storage to displace peak-load demand. Since both costs and benefits show large variations between buildings (climate, occupancy characteristics, load, etc.) and systems (chilled water, ice, eutectic salts), ranges of costs and benefits are compiled from the case studies and available literature and presented.

The costs for installing thermal storage in the California and Maryland case studies ranged from $\$ 250$ to $\$ 337$ per $\mathrm{kW}$ peak cooling capacity. Incremental first costs were between about $\$ 53,000$ and $\$ 63,000$. Other estimates used by utilities having experience with thermal energy storage, summarized below, range from $\$ 76,000$ to almost twice that amount per system. The extreme 
variability in first costs of thermal storage systems relates both to differences between applications (system type and brand, building characteristics, bid procedures and contract type) and to fees of mechanical contractors. In general, low sales of such systems have implied that 1) mechanical contractors are relatively inexperienced in installation and 2) prefabricated components are not usually available (McCannon 1983).

Examples of first cost estimates by two utilities follow. San Diego Gas \& Electric, which has an inducement program to guarantee commercial buildings a 3-year payback on thermal storage systems, estimates a maximum differential cost over conventional air conditioning of about $\$ 58.46$ per ton-hour of storage capacity (McCannon 1983). Ton-hours of storage capacity can range from about 200 to 2500 ton-hours per building. In sample calculations, 1300 ton-hours were assumed for a differential first cost of about $\$ 76,000$ per system. Pacific Gas \& Electric assumes a cost differential of $\$ 255$ per $\mathrm{kW}$ peak demand in some calculations. (a) In one example this cost is based on a San Francisco building with peak cooling load of 624 tons.

Based on the case studies and information presented in this section, it appears that $\$ 76,000$ per system is a reasonably representative first cost for thermal energy storage in cooling applications (as assumed in the San Diego Gas \& Electric sample calculations cited earlier). However, again based on the reviewer literature, actual system first costs may vary from about $\$ 50,000$ to $\$ 150,000$ and depend on several building/system-specific factors.

Operating cost savings to the commercial customer are greatest when timeof-use rates are in effect and negligible if there is only a flat charge for energy use. Annual energy cost savings have been identified ranging from $\$ 16$ to $\$ 36$ per $\mathrm{kW}$ of conventional system capacity (EPRI 1982, McCannon 1983). These estimates are compiled from experiences of Potomac Electric Power Company (PEPCO) and San Diego Gas \& Electric. Assuming a peak cooling load of 250 tons

(a) Laybourn, 0. R., and V. A. Baclawski. 1984. "The Benefits of Thermal Energy Storage for Cooling Commercial Buildings." Pacific Gas and Electric Company, San Francisco, California. 
(880 $\mathrm{kW})$, for example, this would imply annual savings of $\$ 14,080$ to $\$ 32,000$. For a system costing $\$ 76,000$, the simple payback (in this scenario) ranges from 2 to 5 years.

Next we estimate representative benefits to the utility in terms of the magnitude and costs of load displacement. A rule of thumb used by San Diego Gas \& Electric is $1 \mathrm{~kW}$ peak load reduction per ton of conventional airconditioning system capacity (McCannon 1983). For the hypothetical 250-ton system just discussed, this would imply a cost of $\$ 304$ per $\mathrm{kW}$ displaced peak load. (a) Reductions of building energy demand at peak cooling periods ranged in the case studies from $50 \%$ to about $90 \%$ in the case studies, with load shifts most frequently in the upper portion of this range. A representative reduction of summer peak electricity demand by air-cond tioned commercial buildings having thermal storage would be about $80 \%$.

\subsubsection{Potential}

According to one estimate, air conditioning of commercial buildings often accounts for one third of a utility's summertime peak demand (Lannus 1983). What proportion of such peaks could likely be eliminated by the use of thermal storage cooling technology? This section addresses this question and its corollary, the likely magnitude (in MW) of such peak-load reductions.

As explained above in Section 5.6.2, for buildings using thermal storage for cooling, an average peak load reduction of about $80 \%$ is expected. We assumed that the proportion of retrofit applications is small enough to ignore and that all new comnercial buildings are candidates for thermal energy storage. (b)

Among new commercial buildings, market acceptance is likely to depend on first costs and payback periods, inducements (e.g., by the servicing utility),

(a) $\frac{\$ 76,000}{250 \text { tons }} \times \frac{1 \text { ton }}{\mathrm{kW} \text { displaced peak load }}=\$ 304$ per $\mathrm{kW}$ displaced peak load

(b) Baltimore Aircoil (1984) suggests the following types of buildings may benefit from cool storage: office buildings, schools and college buildings, religious institutions, laboratories, large retail stores, libraries, museums and public-use areas of hotels (such as meeting rooms). 
building ownership and business type. In the representative scenario of Section 5.6.2, payback periods ranged from 2 to 5 years. If we adopt the decision rule that the investment occurs only with a simple payback of less than 3 years, and further assume that a quarter of potential applications fall in this category, we obtain an estimated market penetration of $25 \%$ of new conmercial buildings. An optimistic scenario of $50 \%$ market penetration is also analyzed to account for possible incentive plans offered and to provide a range of estimates, allowing sensitivity testing of the market penetration assumption.

Combining these values for market acceptance, technical feasibility and percent reduction of peak load per building using thermal storage, we obtain two scenarios. In one scenario $20 \%$ or in the other $40 \%$ of summer peak loads from new commercial buildings is eliminated due to thermal storage, depending on the market penetration value. These values are applied to baseline projections of peak loads (disaggregated according to commercial-sector contributions by new and existing structures) to obtain a raw estimate of potential MW reduction.

To derive peak load reduction potentials of thermal energy storage for the U.S. as a whole, it is assumed that additions to electricity use are attributable to new buildings all of which are candidates for thermal storage. Although thermal storage may be retrofit to existing cooling systems, on average, we assume this is not a likely option. Using the projections contained in Table 5.1, next to last column, contributions to peak loads from commercial buildings added after 1983 are projected to reach $37.3 \mathrm{GW}$ in 1990 and $58.2 \mathrm{GW}$ in 1995. Hence, at the $20 \%$ and $40 \%$ market penetration levels, rough estimates of potential summer peak load reductions from thermal energy storage are in the range of 7.46 to $14.92 \mathrm{GN}$ in 1990 and from about 11.64 to $23.28 \mathrm{GW}$ in 1995 .

\subsection{USE OF ENERGY MANAGEMENT SYSTEMS}

Energy management systems (EMS) optimize a building's energy use by controlling the times of use of energy-intensive equipment. Computers, monitoring instruments, controls and compunications hardware are some of the tools of EMS. This section first discusses general technical features of EMS, then describes selected applications of EMS in commercial buildings. It further 
extracts values from the case studies and from more general literature to specify a range of costs and energy savings from EMS. Representative values are then chosen to help construct a scenario of the potential national magnitude of reductions in peak demand from EMS in commercial buildings.

\subsubsection{General Features of EMS Technologies}

Although the EMS that is most appropriate for a given building depends on the building owner's objectives, most EMS technologies have some energy-saving features in common. These features include time scheduling of energy-intensive equipment, optimization of HVAC start and stop times, duty cycling of HVAC, and, for peak-shaving, electrical demand control. The following discussion briefly reviews these shared features of EMS technologies as well as typical variations between EMS technologies that significantly affect first costs, flexibility and capabilities.

Time scheduling is a practically universal EMS option. The user or consultant may pre-scheduie start and stop times for lights, air conditioners, fans and heating equipment. Office equipment, such as Xerox machines, may also be pre-programmed to turn on and shut off at scheduled times. Building occupants can usually override any pre-scheduled equipment controls, although with some systems an override intended to affect one room or small area will actually impact a floor or a building. Pre-scheduling saves energy by ensuring that equipment is shut off at typically unoccupied hours, such as nights, weekends and holidays.

Start/stop optimization is a sophisticated variation of time scheduling. The option refers to the automatic adjustment of equipment schedules to reflect environmental conditions. For example, EMS at public schools in Norwalk, Connecticut, turns space conditioning systems on before children get to school just soon enough so that the rooms are comfortable when the students arrive. On very cold days, the HVAC equipment may turn on earlier than on milder days. Shut-off times are also optimized. For example, in winter the HVAC systems turn off whenever the heat already stored in the building structure, coupled with heat contributions by students and lighting, is sufficient to keep 
the building comfortable until the end of the school day (Energy Management Technology 1985c). Environmental sensors and optimization features make the system self-adjusting.

Start and stop times of lighting controls may also be coupled with environmental sensors to optimize energy use. Lights in unoccupied rooms are shut off after a brief interval.

Duty-cycling is another energy-saving feature common to most energy management systems. HVAC equipment is switched on and off depending on the temperature of the conditioned space. Duty-cycling can be integrated with peak demand controls: for example, a system that has both options may shed air conditioning for longer intervals rather than shedding lighting loads.

Electrical demand control allows users to shed lowest-priority loads first in the event that peak demand would otherwise exceed a pre-determined maximum. This feature is particularly cost effective in areas where demand charges are significant. An example of pre-prioritization by manament is in a department store, where air conditioning in the warehouse might be reduced but where it would never be acceptable to cut off operation of floor model appliances during business hours (Calawerts 1984). Alternatively, electrical demand control may allow central, remotely located EMS operators to reduce lighting levels by a pre-determined percentage at several buildings at once in a few seconds. This feature could be useful to utilities in a brown-out situation.

The availability of remote control, the number of circuits simultaneousiy affected by one control, reporting and auditing flexibility and method of installation introduce substantial differences between energy management systems. Remote control allows the EMS contractor or a central of fice manager to control EMS at several buildings at once from a central location. Signals are carried over ordinary telephone lines. The number of circuits requiring controls primarily depends on HVAC features. A centralized HVAC system may require only one control for a large building area, whereas decentralized conditioning may require multiple controls. Materials and installation costs are extremely sensitive to the number of control points. Reporting and auditing features give the user maximum information about energy use and may serve to identify the most promising future energy conservation measures. Finally, EMS 
costs are extremely sensitive to installation requirements. In many cases, EMS must be hard-wired, entailing significant construction and disruption in the user's building. In other cases, however, it is possible for control signals to be carried over existing power lines. Receiving modules are installed at the point of end use to interpret incoming signals in terms of duty-cycling and start and stop times. Powerline carrier systems may reduce first costs considerably where their use is technically feasible.

The above discussion of EMS options is not meant to be exhaustive. It serves to indicate the range of conservation measures available once the decision is made to fine-tune building energy use.

\subsubsection{Description of Cases}

The experiences of four businesses and institutions that use EMS are described in this section. An EMS was added to existing structures in all four cases. Although the technologies used are different, the outcome in all cases is the same: reduced energy consumption, short payback and owner satisfaction. The case studies are a department store in Madison, Wisconsin; an office building in Washington, D.C.; a Calffornia bank with numerous branches; and a medical center in Orange, California.

\subsubsection{Case 1: Department Store in Wisconsin}

The first case study is of an energy management system installed in a retail department store in Madison, Wisconsin (Calawerts 1984). The store is one of several owned by Shopko, Inc. Based on the success at the store in Madison, the chain plans to apply EMS at other stores.

Verheyden Mechanical of Green Bay, Wisconsin, was given responsibility for the approach and solution to energy management for the building. For load control, Verheyden Mechanical selected a Honeywell W700D Series II Load Control. They used Honeywe11 T7400/W7400 Programmable Thermostats to make the system responsive to outside environmental conditions. For peripheral equipment, they chose Honeywell's Q7000 Communication Module, S7400 Interface and Monitor. The result is a comprehensive energy management package. The system permits timeof -day programing of Tighting and HVAC equipment, selective load shedding of low-priority equipment at periods of peak energy usage, and temperature- 
dependent duty cycling (which reduces energy use by HVAC equipment while maintaining comfortable conditions for occupants).

First costs for the energy management system at this 100,000-square-foot store were approximately $\$ 31,000$, (a) Operating savings are about $\$ 18,200$ per year. Simple payback is 1.7 years, and the measure will probably continue to optimize energy use throughout the building's life as a department store.

The benefits of EMS at the ShopKo store are impressive. Consumption of energy ( $k$ Wh) and peak energy $(k W)$ both dropped. Current and past energy usage are easily compared because Verheyden Mechanical compiled the building's past history of energy consumption as part of EMS planning. Average daily kWh consumption is reduced to $6749 \mathrm{kWh}$ from $7589 \mathrm{klhh}(11 \%)$. The average peak, formerly $449 \mathrm{~kW}$, is now $424 \mathrm{~kW}$ (a $6 \%$ reduction).

\subsubsection{Case 2: 12-Story Office Building in Washington, 0.C.}

The second case study is of an energy management system at the Motion Picture Association office building in Washington, D.C. (McGil1 1984a). A minimum-cost energy management system was installed to control HVAC equipment in this 12-story, 13-year-old building. The initial system permitted modular expansion; 2 to 3 modules per month are being added to control lights and some office equipment. Existing building wiring supports the system, a feature which substantially reduces first costs over a hard-wired system.

The Motion Picture Association building uses a powerline carrier system by Leviton Manufacturing Co., Inc., Little Neck, New York. This system was recommended hy their electrical contractor, Auguste Electrical Service. Potomac Electric Power Company (PEPCO) is also involved in this building energy conservation measure through the Curtailed Load Program to induce customer electricity demand curtailment during periods of heavy demand. PEPCO gives rebate credits for $\mathrm{kW}$ reductions to predetermined "firm service level." (b)

(a) Reference year fon dollars not given in Calawerts (1984). (b) See discussion in Section 5.4.1. 
The powertine carrier energy management system cost $\$ 5,685$ installed. (a) The system produced $\$ 20,000$ savings in the first year. The building's electric bi11s, which formerly were $\$ 24,000$ per month in the summer and $\$ 10,000$ per month in the winter, were reduced significantly.

The system is credited with $226,000 \mathrm{~kW}$ savings in the first year. The avoided costs due to the system's installation are appreciated by the customer. However, the customer appears to be somewhat concerned about the cost effectiveness of reducing electrical demand much further, should such action be requested by the utility. (b)

5.7.2.3 Case 3: Wells Fargo Bank in California

The third case study is of an energy management system at the Wells Fargo Bank in California (McGili 1984b). EMS controls energy loads at branch offices via signals carried by telephone lines. The system is $80 \%$ in place and will eventually manage energy use with remote controls for all of the bank's 375 California branches.

The bank is using EMS by Margaux Controls, distributed by Trimax Distribution Division of San Jose, California. The bank is contracting with CommAir Mechanical Services of Oakiand, California, for single-source installation. System features include duty cycling of HVAC equipment, control of interior lights and demand limiting of peak loads.

Wells Fargo will have paid $\$ 3$ million over a two-year period for the system when it is completely installed, (c) The bank expects approximately $\$ 1.5$ million per year savings, due to about a $25 \%$ reduction from a utility bill of $\$ 8.5$ million. The expected return on investment is $50 \%$. In some branches, the percentage reduction in utility bills is higher. For example, natural gas costs dropped by more than $50 \%$ when the system was installed at the 0akland, California, branch.

(a) Reference year for dollar not cited in Calawerts (1984).

(b) Fred Jaeschke, V. P. General Manager, as cited in Walker-Davis Publications, Inc. 1984c).

(c) Reference year for constant dollar not cited in McGill (1984b). 
It is difficult to allocate the energy savings of the Wells Fargo EMS to specific servicing utilities. Eight different gas companies, 28 suppliers of electricity and more than 100 water companies are involved. However, the expected cost reductions of $25 \%$ indicate substantial energy savings both in overall consumption and at peak periods.

5.7.2.4 Case 4: Batavia Woods Medical Center in Orange, California

The last case study is of a powerline carrier energy management system installed at the Batavia Woods Medical Center in Orange, California (Energy Management Technology 1985b). This system is of interest because of both its low first costs (characteristic of powerline carrier EMS) and the substantial incentives offered by utilities and the state. Energy Design Consultants of Santa Ana, California, recommended the system, which consists of three powerline carrier energy management systems by Solidyne of Schaumberg, Illinois (the Solidyne Micromizer PLC EMS).

The system required capital outlays of $\$ 32,000$ (a) The bid was $\$ 0.55$ per square foot on the 60,000-square-foot complex of medical buildings. Mard-wired EMS for the medical center would have cost $\$ 0.75$ to $\$ 1.00$ per square foot, a prohibitively expensive increment of 36 to $82 \%$. The system was eligible for rebates from Southern California Edison Company (\$9000) and Southern California Gas Company (\$1000), and it was also awarded a California tax credit of $\$ 8000$. Actual net investment by the Medical Center was therefore only $\$ 14,000$. This sum was recovered in less than a year by energy savings of $\$ 17,800$ the first year.

EMS at the Batavia Woods Medical Center reduced kWh consumption by $15 \%$. Had there been no rebates, simple payback would have been less than 2 years. 5.7.3 Range of Costs and Benefits

Payback periods on energy management systems appear to be short for both new and retrofit commercial buildings. Paybacks were less than 2 years in all four cases, and according to industry expert Reg Zurinskas of General Electric,

(a) Reference year for dollar not cited in Energy Management Technology (1985b). 
this is typical. (a) Thus, although there is a large range of first costs, depending on building-specific features and control options, EMS are generally economical to install.

Energy consumption was reduced by 11 to $25 \%$ in the case studies. Larger or smaller savings are realized depending on a building's prior energy use. (b) In addition, several systems featured peak demand load control options. These pre-prioritization features are particularly pertinent options for commercial customers faced with peak power constraints. If it is assumed that peak load reduction is about half as much as $\mathrm{kWh}$ reduction in relative terms, then the range of reductions in individual cases is from 6 to $13 \%$.

\section{7 .4 Potential}

Energy management systems are an extremely promising potential consumer response to supply constraints. They not only reduce baseline energy use by commercial buildings, but also build flexibility into a building's load. If rates increase or rate structures change, an EMS is easily re-programmed to minimize overall changes in building operating costs. For example, suppose demand charges increase. Systems equipped with electrical demand control permit the orderly shedding of loads at the least cost to the customer. EMS usually is easily interfaced with remote control systems. In a brown-out or demand reduction situation, any pre-programmed amount of load connected to EMS quickly can be shed in response to a utility's request.

Most commercial buildings, both new and existing, can benefit from some type of energy management system. Numerous products are available (Energy User News 1984). EMS technologies seem to have gone through severai generations of development in a very brief time period (Weaver 1983, Williams 1984). Rapid changes, which make EMS even more widely applicable and economical, is likely to continue as rapid technical change continues to characterize the related fields of microprocessing and telecomunications.

(a) Personal communication, Reg. Zurinskas, April 1985.

(b) The range of energy use reductions in the case studies is comparable to the 15 to $20 \%$ potential per building cited in Energy Management Technology (1983). 
EMS technologies are the tools of smart building management. Consumer acceptance appears to he very high. There are several success stories attesting to the value of EMS. Paybacks tend to be short and returns on investment high. Growing markets will likely characterize EMS in the future.

Energy management systems appear to have high energy-savings potential. However, in assessments of potential future energy savings, existing structures that have already installed EMS should be excluded. (a) In addition, absolute amounts of conserved energy (as opposed to percentages of building energy use) are likely to be smaller on new buildings than on existing structures. This difference is attributable to the lower average energy use of newly constructed commercial buildings.

For the purpose of illustrating the peak load reduction potential of EMS in commercial buildings, assume that approximately $5 \%$ of the commercial electric loads would have instailed EMS by 1990 , and $10 \%$ by 1995 . To be conservative, assume that EMS will, on the average, reduce peak load by $5 \%$ per site. Combining these assumptions with the projected comercial-sector contribution to system peak loads presented in Table 5.1 yields peak load reductions of $0.38 \mathrm{GW}$ in 1990 and $0.86 \mathrm{GW}$ in 1995 . (b)

\subsection{SUMMARY OF FINDINGS}

A preliminary and limited review of the literature on commercial sector responses to electricity supply constraints and high electricity prices is conducted in this Chapter. Five specific response areas are covered: time-of-use rates, interruptible rates, cogeneration, thermal energy storage, and energy management systems. In summary, the following findings are noted.

1. In response areas involving utility-initiated voluntary or optional programs such as Tou rates and interruptible rates, commercial customer participation is an important issue. Sketchy information

\footnotetext{
(a) A 1983 estimate indicated that approximately $7 \%$ of commercial buildings that could potentially use EMS were doing so (Energy Management Technology 1983). The percentage now is probably greater.

(b) For $1990,151.7 \times(0.05) \times(0.05)=0.38$. For $1995,172.6 \times(0.05) \times$ $(0.1)=0.86$
} 
concerning actual participation rates suggests that participation in optional programs is generally low. Factors contributing to low participation rates include lack of understanding, perceived lack of money-saving opportunities, perceived difficulties in changing the operation schedules, concerns about tenants and customer comfort and convenience. To increase participation in such optional programs, marketing efforts need to be initiated.

2. In mandatory utility-initiated programs, participation is not an issue. Such programs generally cover the largest utility customers, although there are also examples of medium to large customers being covered in mandatory programs, such as in PG\&E's A-21 and A-22 rate schedules.

3. In response areas involving commercial businesses' adoption of specific energy efficient or load management technologies, such as cogeneration, thermal energy storage, and energy management systems, the rates of penetration of the technologies are affected by factors such as the potential benefits of the technologies, the initial costs, the possible interruption of on-going business operations, and the availability and credibility of information concerning the technologies, as well as other factors.

This analysis did not attempt to conduct a comprehensive review of the penetration rates of such technologies. Nevertheless, the individual cases described suggest that the selected technologies have payback periods or internal rates of return that are attractive to business firms. This means that penetration of these technologies can be increased through the passage of time, better dissemination of information concerning the costs and benefits of the technologies, provision of technical assistance and financial incentives.

4. Actual experience with the five selected response areas indicated that they are effective in reducing the utility commercial customers' load during the on-peak period. On an individual utility system or individual business basis, the following ranges of relative or absolute reductions of summer peak load have been observed: 
Response Area

Time-of-use rates:

Interruptible rates:

Cogeneration:

Thermal energy storage:
Individual Peak Load Reductions

$1.6 \%$ to $10 \%$

$5 \%$ to $40 \%$

$70 \mathrm{~kW}$ to $1000 \mathrm{~kW}$ per installation

$50 \%$ to $90 \%$

$6 \%$ to $13 \%$

5. Based on assumptions concerning participation rates, penetration rates and peak load reductions of the five response areas, which are formulated judgmentally from the analyses described above, rough estimates of peak load reductions are derived for 1990 and 1995 for the U.S. as a whole. These peak load reduction potentials are as follows:

\begin{tabular}{lll}
\multicolumn{1}{c}{ Response Area } & & $\begin{array}{c}\text { Total U.S. Commercial } \\
\text { Sector Peak Load } \\
\text { Reduction Potential, GW }\end{array}$ \\
\cline { 1 - 1 } Time-of-use rates & $\frac{1990}{0.6}$ & $\frac{1995}{0.7}$ \\
Interruptible rates & 3.0 & 3.5 \\
Cogeneration & 2.5 & 6.4 \\
Thermal energy storage & 7.5 to 14.9 & 11.6 to 23.3 \\
Energy management systems & 0.4 & 0.9
\end{tabular}

These estimates of peak load reduction potentials are highly tentative and dependent upon the postulated assumptions concerning the participation and penetration rates, and the individual peak reduction rates. Although "conservative" assumptions have been made in deriving these estimates of peak load reduction potentials, they should be regarded as preliminary illustrations only.

6. Some of these response areas are likely to be interrelated in the sense that actions in one response area would reduce the potential peak load reductions of actions in other areas. In other cases, actions in one response area would stimulate actions in other 
areas. Interpretations of the above potential peak load reduction estimates should take these aspects into consideration. In particular, since the interrelations among the response areas are not included in the estimates, they should not be added up without adjusting for possible double counting of peak load reduction potentials.

Finally, it should be noted that this review and analysis is preliminary and limited in several senses. First, the search of the relevant literature was not comprehensive and the number of cases selected for each response area is fairly small. Second, some potentially useful response areas are not covered. Third, the approach to approximate the potential peak load reductions of the response areas is simplistic. Given these caveats, it is clear from the analysis in this Chapter that there are potential ways in which the commercial sector can reduce its peak loads to alleviate the potential adverse impact of electricity supply constraints on the growth of business activities.

It follows from the above discussion that further analyses and studies, if they are to be conducted, should be aimed at addressing the limitations of this preliminary analysis by conducting a more comprehensive review of the literature, by including additional case studies, and by using a more refined methodology to derive estimates of peak shaving potentials, including better justifications and substantiations of the assumptions made.

\subsection{REFERENCES}

Aigner, D. J., and D. J. Poirie, 1979. Electricity Demand and Consumption by Time-of-Use: A Survey, EPRI EA-1294, Final Report, Electric Power Research Institute, Palo ATto, California.

American Gas Association. 1985. Guide to New Natural Gas Utilization Technologies, ed. Nelson E. Hay. The Fairmont Press, Inc., Atlanta, Georgia.

Angel Economic Reports, and Heberlein-Baumgartner Research Services (AER/HBRS) 1984. Customer Attitudes and Response to Load Management, RDS 95, Electric Power Research Institute, Palo Alto, California. 
Arthur D. Little, Inc. 1983. Review and Evaiuation of Pacific Gas and Electric Company's Group Load Curtailment Program, prepared for Pacific Gas and Electric Company, by Arthur D. Little Co., San Francisco, California.

Baltimore Aircoil. 1984. A Guide to Ice Storage System Design. Bulletin E140/1-0 A; Merck and Company, Inc. AD/3M/7-84. Ba1timore Aircoil, Baltimore, Maryland.

Binkley, James, et al. 1982a. "Energy for Sales." Progressive Architecture, August 1982.

Binkley, James, et al. 1982b. "Bed, Board, and Btu's." Progressive Architecture, December 1982.

Binkley, James, et a1. 1983. "Energy to Recover." Progressive Architecture, February 1983.

Calawerts, C. ed. 1984. "Carefully Conceived EMS Slashes Department Store Costs." Energy Management Technology. 8(7):30,63-65.

Carlson, Steve. 1979. "Wisconsin Power and Light's Experiment with Large Industrial and Commercial Time-of-Day (TOU) Rates," in Modeling and Analysis of Electricity Demand by Time-of-Day, EPRI EA-1304, pp. 13-5 through 13-15. Electric Power Research Institute, Palo Alto, California.

Charles River Associates. 1984. Marketing Strategies for New Alternative Rates for Small Commercial Customers, CRA Report No. 794, prepared for Pacific Gas and Electric Company by Charles River Associates, Boston, Massachusetts. November.

Creighton, T. E., 1979. "Response of Very Large Customers to Time-of-Use Electric Pricing: Pacific Gas and Electric Co.'s A-17 Rate", in Modeling and Analysis of Electricity Demand by Time-of-Day, EPRI EA-1304, pp. $13-15$ through 13-27. ETectric Power Research Institute, Palo Alto, California.

Davidson, Keith. 1984. "National Potential for Cogeneration in the Commercial Sector." Presented at ASHRAE/ICS Fourth Annual Cogeneration Seminar, June 20, 1984. Gas Research Institute, Chicago, Illinots.

Davidson, Keith G., and William Krauss. 1985. "Packaged Cogeneration Systems for Commercial Buildings." Paper prepared for the 16th World Gas Conference, June 24-27, 1985, Munich, Germany. Gas Research Institute, Chicago, Illinois.

DeSimone, L. E., J. S. Parsons, and N. A. Tschderer, 1979. "A Qualitative Evaluation of Price Responses Associated with San Diego Gas and Electric's Time-of-Use Rate for Large Customers," in Modeling and Analys is of Electricity Demand by Time-of-Day, EPRI EA-1304, Workshop proceedings, pp. 13-28 through 13-50. ETectric Power Research Institute, Palo Alto, California. 
Dunckel, Earl. 1984. "Cogeneration Looms Large in \$ Multi-million Gas Research." Cogeneration, 1(4):36.

Electric Power Research Institute (EPRI). 1982. Thermal Energy Storage: Cooling Commercial Butldings Using Off-Peak Energy, EM-2244, EPRI, Proceedings February 1982, Palo Alto, California.

Energy Management Technology. 1983. "U.S. Buildings Could Save Billions With Proper Energy Management." Energy Management Technology. $7(7): 6$.

Energy User News. 1984. "Energy Technology Buyer's Guide--1985." Energy User News, December 31, 1984.

Energy Management Technology. 1984. "Smal1 Scale Cogeneration Curbs Rising Energy Costs." Energy Management Technology. 8(7):24-25.

Energy Management Technology. 1985a. "University Cogeneration System Shaves Peak Demand Costs." Energy Management Technology. 9(1):40-41.

Energy Management Technology. 1985b. "PLC Energy Savings Prescribed for Sprawling Medical Center." Energy Management Technology. 9(1):26-28.

Energy Management Technology. 1985c. "Self-Funding System Saves Fuel for Public. Schools." Energy Management Technology. 9(2):38-39.

Gas Research Institute. 1984. "Cogeneration for the Commercial Sector: A Technology That's Here to Stay." Gas Research Institute Digest, Volume 7, Number 5. Gas Research Institute, Chicago, Illinois.

Gas Research Institute. 1985. "Cogeneration Package Helps Hospital Cut Costs." Gas Research Institute Digest, Volume 8, Number 1. Gas Research Institute, Chicago, Illinois.

Johnson, W. A., A. M. Maher, and T. M. Devaney. 1985. "Experimental Results of a Load Management System for Large Commercial Customers," paper presented at IEEE Power System Engineering 1985 Winter Meeting, Fobruary 3-8, New York.

Keelin, T. W., et al. 1982. "Generating Capacity in U.S. Electric Utilities: How Is It Used? How Much is Needed Over the Decade?" EA-2639-SR. Electric Power Research Institute, Palo Alto, California.

Kostrzewa, Lawrence J. 1984. "Natural Gas Cogeneration: Applications, Economics, and Opportunities." Paper No. 84-F-600, presented at the 1984 Fall Meeting, Electrical Generating Systems Association. Gas Research Institute, Chicago, I1linois.

Lannus, Arvo. 1983. "Cool Storage in the Commercial Sector." EPRI Journal, Vol. 8, No. 8, October. 
Lawn, John. 1983. "Wi11 Commercial Cogeneration Come Out of the Closet?" Energy Management. Apri 1, pp. 22-26, 56.

Lawrence, A. G., T. A. Heberlein and R. M. Baumgartner. 1984. Customer Attitudes and Response to Load Management. RD 95, Electric Power Research Institute, Palo Aito, California.

McCannon, Loren W. 1983. Thermal Energy Storage: Inducenent Program for Commercial Space Cooling. San Diego Gas and Electric, San Diego, Californita.

MeGill, F. ed. 1984a. "A Cost-Effective Way to Cut Back Electrical Loads." Energy Management Technology. $7(9): 38-40$.

Mclaill, F. ed. 1984b. "Bank Invests in Statewide EMS." Energy Management Technology. 8(5):28-29.

Mosback, J., et al. 1979. Power Shortage Costs and Efforts to Minimize: An Example, EA-1241, Electric Power Research Institute, Palo Alto, California.

North American Electric Reliability Council (NERC). 1984. Electric Power Supply and Demand: 1984-1993. North Nmerican Electric Reliability Council, Princeton, New Jersey.

Pacific Gas and Electric Company, 1983a. Small Commercial Time-of-Use Experiment, 1981-1982. PG\&E, San Francisco, California.

Pacific Gas and Electric Company. 1983b. Group Load Curtailment, 1982 Load Analysis Report. PG\&E, San Francisco, California.

Potomac Electric Power Company. 1984. "Rate Schedules for Electric Service in the District of Columbia." Potomac Electric Power Company, Washington, D.C.

Powe11, W.P., 1979. "Southern California Edison Company Effects of Time-ofUse Rate (TOU-8) on the Very Large Power Customers," in Modeling and Analysis of Electricity Demand by Time-of-Day. EPRI EA-1304, Workshop proceedings, pp. 13-50 through 13-53, Electric Power Research Institute, Palo Alto, California.

Sanghvi, A. P. 1982, "Economic Costs of Electricity Supply Interruptions: J.S. and Foreign Experience." Energy Economics. 4(3):180-198.

The Sievert Corporation. 1983. Packaged Gas-Fired Cogeneration Systems Development for Fast Food Restaurants. Published by Gas Research Institute, GRI-82/0059, Chicago, Illinois.

Speilvogel, Lawrence G., and Andrew Rudin. 1984. "Religious Building Energy Use." ASHRAE Journal. 26(1):40-45. 
Sturdivant, J. J., 1982. Time-of-Use Study for Large Electric Commercial and Industrial Customers (greater than $4500 \mathrm{~kW}$ ), San Diego Gas and Electric Company, San Diego, Californía.

U.S. DOE. 1984a. Annual Energy Out look 1983 with Projections to 1995. DOE/EIA-0383(83), Department of Energy, Energy Information Administration Washington, D.C.

U.S. DOE. 1984b. Annual Energy Outlook, 1983. DOE/EIA-0383(83), Department of Energy, Energy Information Administration, Washington, D.C.

U.S. DOE. 1984c. Energy Conservation Mu1ti-Year Plan FY 1986 - FY 1990. Department of Energy, Office of Conservation, Washington, D.C.

U.S. DOE. 1985. Annual Energy Outlook 1984 with Projections to 1995. DOE/EIA-0383(84), Department of Energy, Energy Information Administration, Washington, D.C.

U.S. DOE. 1986. Commercial Cogeneration Predicted Capacity. Department of Energy, Washington, D.C.

Waukesha. 1984. Bulletin 1290, August. Waukesha/Dresser Industries, Waukesha, Wisconsin.

Weaver, Mark. 1983. "Smert FIDs Oust CPUs in Distributed Process EMS." Energy User News. $8(22): 1,10$.

E. H. White and Co., 1984. Survey of Small Commercial Customers on the A-20 Time of Use Rate Schedule, Final Report, prepared for Pacific Gas and Electric Company, San Francisco, California.

Williams, Verle A. 1984. "Direct Digital Control." ASHRAE Journal. 26(11):45 46 . 


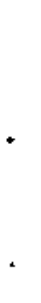


DISTRIBUTION

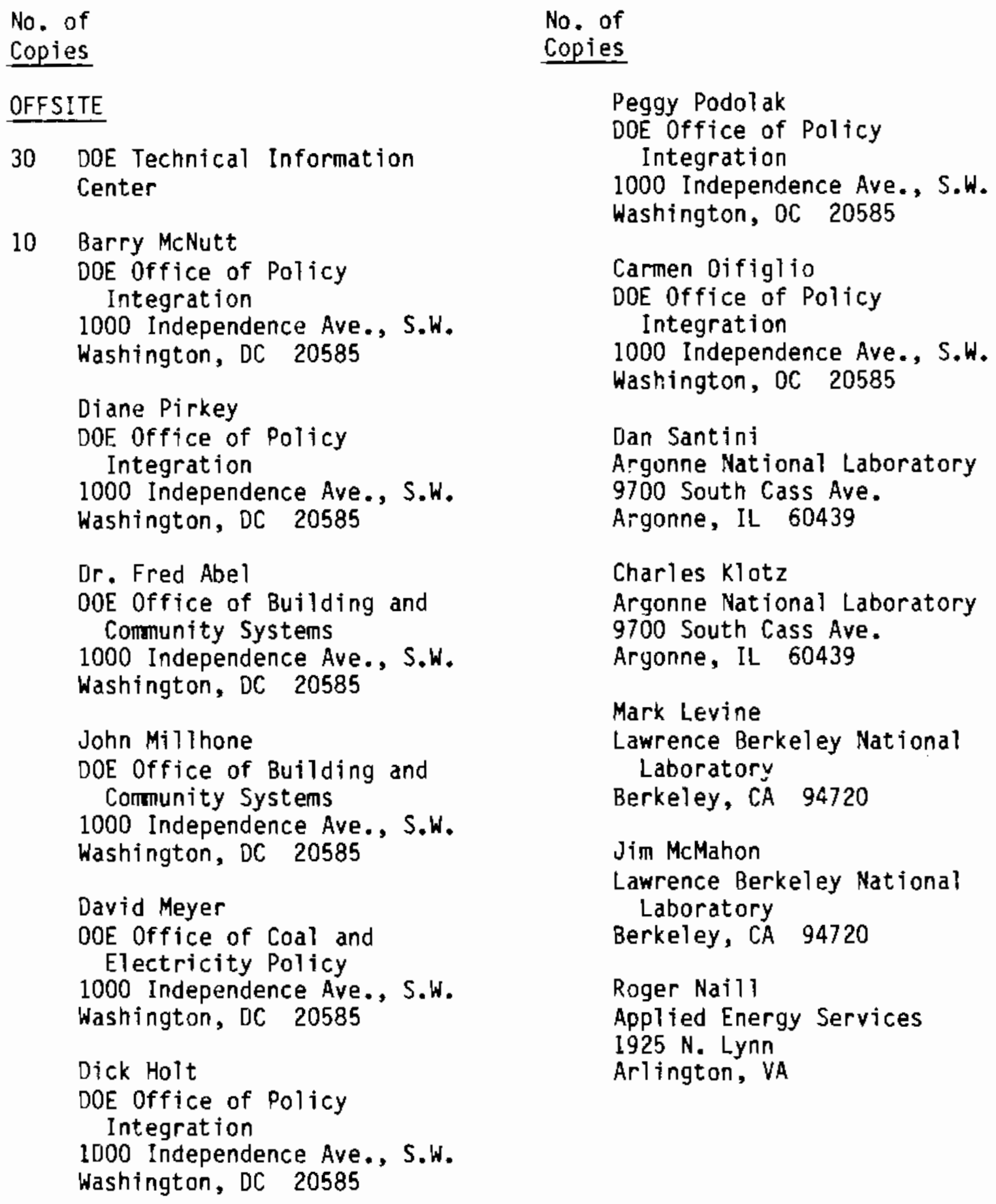

Peggy Podolak 
No. of

Copies

Vito Stagliano

DOE Office of Policy Integration

1000 Independence Ave., S.W.

Washington, DDC 20585

Kenneth Friedman

DOE Office of Conservation and Renewable Energy

1000 Independence Ave., S.W.

Washington, DC 20585

Harvey Major

DOE Office of Conservation and Renewable Energy

1000 Independence Ave., S.W. Washington, DC 20585

Margaret Sibley

DOE Office of Policy

Integration

1000 Independence Ave., S.W.

Washington, DC 20585

Mike King

Synergic Resource Corp.

1511 Third Ave., Suite 1018

Seattle, WA 98101
No. of

Copies

ONSITE

DOE Richland Operation Office

J. J. Sutey

33 Pacific Northwest Laboratory

R. M. Scheer (10)

R. J. Moe

M. S. Klan

R. C. Adams

Z. J. Fisher (5)

R. C. Tepel

J. M. Fang

A. J. Lyke

J. L. Brajtman

J. W. Hurwitch

W. B. Ashton

J. W. Thielman

C. A. Geffen

Publishing Coordination $\mathrm{MH}$ (2)

Technical Information(5) 